INEEL/EXT-98-00892

September 1998

\title{
SELECTED \\ COMPONENT \\ FAILURE RATE \\ VALUES FROM \\ FUSION SAFETY \\ ASSESSMENT TASKS
}

L. C. Cadwallader

LOCKHEED MARTIN 
INEEL/EXT-98-00892

\section{Selected Component Failure Rate Values}

\section{from Fusion Safety Assessment Tasks}

L. C. Cadwallader

Published September 1998

Idaho National Engineering and Environmental Laboratory Nuclear Engineering Technologies Department Lockheed Martin Idaho Technologies Company Idaho Falls, ID 83415-3860

Prepared for the

U.S. Department of Energy Office of Energy Research Under the DOE Field Office, Idaho Contract No. DE-AC07-94ID13223 


\begin{abstract}
This report is a compilation of component failure rate and repair rate values that can be used in magnetic fusion safety assessment tasks. Several safety systems are examined, such as gas cleanup systems and plasma shutdown systems. Vacuum system component reliability values, including large vacuum chambers, have been reviewed. Values for water cooling system components have also been reported here. The report concludes with the examination of some equipment important to personnel safety, primarily sensors to detect hazardous conditions such as oxygen deficiency, toxic gas atmospheres, combustible gases, and airborne releases of radioactivity. These data should be useful to system designers to calculate scoping values for the availability and repair intervals for their systems, and for probabilistic safety or risk analysts to assess fusion systems for safety of the public and the workers.
\end{abstract}




\section{SUMMARY}

This report is a compilation of component failure rate and repair rate values that can be used in magnetic fusion safety assessment tasks. The data were collected from literature reviews of fission, fusion, and other industrial equipment operating experiences, and by use of analyst judgment. The values given here have been used for safety and environmental assessments during the course of the International Thermonuclear Experimental Reactor (ITER) Engineering Design Activity (EDA). One purpose of this report is to archive the data. The second purpose is to document the data for possible future uses on other designs. Since these data are rather generic in nature they can be useful to other magnetic fusion designs that use plant equipment similar to ITER, such as vent stack gas cleanup systems and plasma shutdown systems. Failure and repair rates for vacuum system components are also included here. Values for water cooling system components have also been harvested and are reported here. The report concludes with the examination of some equipment important to personnel safety, primarily sensors to detect hazardous conditions such as oxygen deficiency, toxic gases in the atmosphere, combustible gas releases, and airborne releases of radioactivity. The third purpose of this report is to compile data that are useful to the International Energy Agency's Cooperative Agreement on the Environmental, Safety and Economic Aspects of Fusion Energy. Task 7 in that agreement is the collaboration of interested parties to construct a data bank of component failure rate data for magnetic fusion usage. This report should be useful to system designers to calculate scoping values for the availability and repair intervals for their systems, and for probabilistic safety or risk analysts to assess fusion systems for safety of the public and the workers. 


\section{ACRONYMS}

ASME American Society of Mechanical Engineers

B\&PV Boiler and Pressure Vessel Code

BWG Birmingham wire gauge

CANDU Canadian Deuterium-Uranium fission reactor

$\mathrm{cm} \quad$ centimeter

EDA Engineering Design Activity

ENEA Ente per le Nuove Tecnologie, l'Energia e l'Ambiente

(Agency for New Technologies, of Energy in the Environment)

FNAL Fermi National Accelerator Laboratory

GDRD General Design Requirements Document

HEI Heat Exchange Institute

HEPA High efficiency particulate air filter

IAEA International Atomic Energy Agency

IEA International Energy Agency

INTOR International Torus

ITER International Thermonuclear Experimental Reactor

$\mathrm{kg} / \mathrm{s} \quad$ kilograms per second

$\mathrm{kW} \quad$ kilowatts

LOCA loss of coolant accident

$\mathrm{m} / \mathrm{s} \quad$ meters per second

$\mathrm{mm} \quad$ millimeter

MW megawatts

NFPA National Fire Protection Association

NSSR Non-site Specific Safety Report

OREDA Offshore Reliability Data

$\mathrm{Pa} \quad$ Pascal

PHTS Primary Heat Transport System

PRA Probabilistic Risk Assessment

RH remote handling

TEMA Tubular Exchanger Manufacturers Association

VV vacuum vessel 


\section{CONTENTS}

ABSTRACT

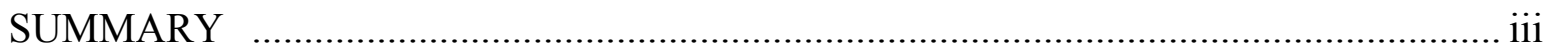

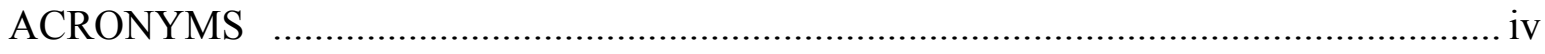

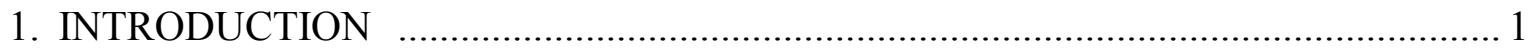

2. SELECTED SAFETY SYSTEM FAILURE RATES ............................................. 3

$2.1 \quad$ Stack Cleanup System ....................................................................... 3

2.2 Plasma Shutdown System ……............................................................. 10

2.3 Vacuum Vessel Pressure Suppression Rupture Disks................................ 12

3. VACUUM VESSEL COMPONENT FAILURE AND REPAIR RATES.................... 23

4. HEAT TRANSFER SYSTEM COMPONENT FAILURE AND REPAIR RATES ....... 35

5. SELECTED PERSONNEL SAFETY COMPONENT FAILURE RATES .................... 57

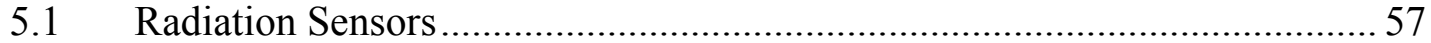

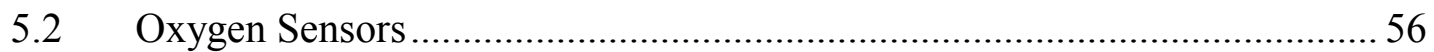

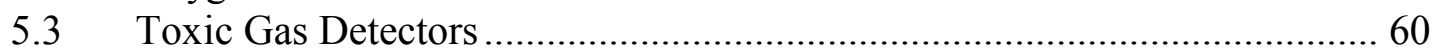

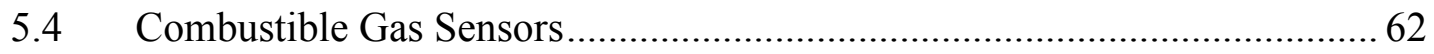

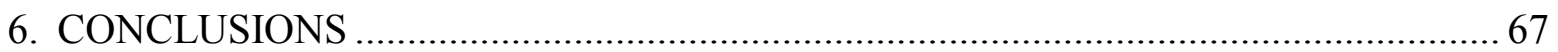

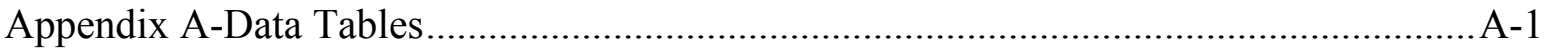

\section{TABLES}

Table 1. Safety System Component Failure Rates ..................................................... 15

Table 2. Savannah River K Reactor Heat Exchanger Parameters ................................... 47

Table 3. Summary of Leaks in Savannah River Heat Exchangers .................................. 49 


\section{Selected Component Failure Rate Values from Fusion Safety Assessment Tasks}

\section{INTRODUCTION}

This report is a compilation of the failure rate values supplied to the International Thermonuclear Experimental Reactor (ITER) safety assessment effort during the Engineering Design Activity (EDA). Many different equipment items were addressed, including safety system demand failure rates, confinement boundary vacuum equipment, fluid system components, and some equipment for personnel safety. These data are presented in the following chapters, with an explanation of the data source and why these data are applicable to fusion experiments.

These data were used in ITER safety assessment, such as the Non-site Specific Safety Report (NSSR), and they can also be useful to other fusion experiments that use equipment similar to ITER. Other designs with similar engineered safety features, large vacuum chambers, water cooling, or other generally similar system equipment to maintain can make use of these data. The values reported here can be used as inference scoping values (see Cadwallader and Marshall, 1996 for a discussion on inference) until more accurate failure rates are obtained from equipment reliability studies by vendors, reduction of pertinent experience data from operating tokamaks, performance of accelerated life testing on new component designs, or other means. These other methods to gain accurate reliability data are expensive and time consuming; it will be some time before the fusion community is able to compile a large reliability data bank. Until then, these data will suffice for support of semi-probabilistic, semi-deterministic safety assessments.

Collection of component failure rate data is one of the tasks in the International Energy Agency (IEA) cooperative agreement on Environmental, Safety and Economic Aspects of Fusion Energy. The data given in this report add to the scoping data sets (for example, Cadwallader and Piet, 1989) that are already published to share with the fusion safety community. As part of the IEA task, then Italian fusion safety researchers at ENEA are constructing a personal computer data bank for use in risk assessment and probabilistic safety analysis. Future data sets will be stored in spreadsheet form to allow importation into the data bank. 


\section{Chapter 1 References}

Cadwallader and Marshall, 1996. L. C. Cadwallader and T. D. Marshall, "Component Reliability Data Estimation for Fusion Safety and Risk Assessment," International Topical Meeting on Probabilistic Safety Assessment (PSA '96), Park City, UT, September 29-October 3, 1996, volume 1, pages 637-648.

Cadwallader and Piet, $1989 . \quad$ L. C. Cadwallader and S. J. Piet, 1989 Failure Rate Screening Data for Fusion Reliability and Risk Analysis, EGG-FSP-8709, September 1989. 


\section{SELECTED SAFETY SYSTEM FAILURE RATES}

There are several items to consider when constructing event trees for fusion safety assessment. There are the initiating event frequencies to determine, identification of systems that respond to these initiating events, and the probability that these systems function in a given event. This chapter presents the demand probabilities of selected safety systems responding to postulated initiating events. The safety systems under consideration here are the passive stack cleanup system (blow-out panels, scrubbers, dryers, ductwork, and stack), the plasma shutdown system, and the rupture disks that relieve vacuum vessel steam overpressure to a pressure suppression system. Bounds of structural reliability will also be discussed regarding the building stack, to treat the influences on building overpressure levels and ground level building leakage.

\subsection{Stack Cleanup System}

A stack cleanup system would be used to cleanse and vent steam overpressure during an ex-vessel loss of coolant accident. Blow out panels in the walls near the cooling systems are routed to metal piping ducts (perhaps stainless steel). These ducts convey the steam and water to scrubbers and dryers, then to filters. From there, the cleaned, dry steam travels out the facility vent stack. The design intent is that the only driving force is steam pressure; there are no fans, compressors, or blowers in the system. Therefore, representative data on the pressure drops of the scrubbers and other equipment items will be given here for later analysis.

Blow-out panels. These panels have been used in various industries that deal with explosive gases, dusts, liquids, or solids. The panels have various names, such as flaps, pop-out panels, rupture panels, hinged panels, hinged louvers, rupture discs, tethered panels, explosion vents, etc. The design idea is that these panels will fail at a preset pressure so that explosion pressure in a room is relieved without distressing the building walls or sensitive equipment in the room, whichever is most susceptible to overpressure. There is much literature devoted to calculating the maximum overpressure that can be realized and appropriately sizing the vent area.

There are two causes for concern with these panels. The first is that they open at the required pressure; that is, they open on demand. If they open too late or not at all, then the room overpressurizes and this could lead to radioactive materials being vented out of room wall penetrations or doors, etc., instead of being vented to the cleanup systems. The second potential problem is the panels leaking room air into the duct lines. The inleakage air (with atmospheric humidity) could degrade the quality of the response of the scrubber/dryer/filter so that it is not efficient in cleaning the accident steam - either humidity contaminating the equipment so that it could corrode or have other degradation, or lading the filters so that they are already full of dust and humidity, resulting in higher pressures in the duct lines. Each of these concerns is discussed below. 
Panel failure rates for opening on demand have not been found in the literature. One paper by Rajagopalan and Camacho (1989) discussed the use of these panels to mitigate potential steam pipe breaks in Canadian fission reactors. They did not have reliability data on the panels, but gave the panels between 1E-03 to 1E-04/demand failure rate (higher rate for large steam line breaks, lower rate for loss of coolant accidents). They indicated that the panels in use all passed rupture tests, so there is high confidence in these failure rates. Many panels of this type are reusable, so they can be tested. The higher rate is suggested to be used (1E-03/demand) for these panels, since this is conservative; these are panels for similar applications with a similar pressure rating (15 $\mathrm{kPa}$-differential pressure) but the main steam line break in a Canadian fission reactor is more severe than an ITER loss of coolant accident. Overall, the Canadian panels are roughly $161 \mathrm{~cm}$ by $54 \mathrm{~cm}$, and are composed of two stainless steel thin sheets sandwiching a polymeric sealing membrane. An important design consideration from the literature is that the panels do not reclose when they reach the end of their travel (i.e., possibly rebounding and reclosing). Many hinged panels have hooks or clasps to catch and hold the panels open after the panel moves. This design precaution was not mentioned by Rajagopalan and Camacho (1989), so it is assumed that it is not a problem for the particular panel design to be used in Canada.

In an effort to verify the $1 \mathrm{E}-03 / \mathrm{d}$ failure rate, the literature on rupture panels was reviewed both electronically and manually. No other failure rates were found in that search. Review of literature on the design of panels shows that design guidance is to provide the exact panel size needed to relieve the pressure; there is no suggested design margin built in (such as an extra 20\% area or et cetera) to account for faulty panels (Rust, 1979; NFPA, 1994). This strict design to match the panel area with the calculated explosion vent area without any added design conservatism suggests that the panels historically have been reliable, and panel failure rates in the $1 \mathrm{E}-03$ to $1 \mathrm{E}-04$ per demand range seem more reasonable. Other literature citations showed that the panels are (qualitatively) reputed to work well (Naidus, 1981; Moore, 1989; Dainty et al, 1990). This is probably due to their design simplicity.

Blow-out panels are said to typically respond within 50 milliseconds (Naidus, 1981) of the beginning of an overpressure condition - the panels are specified to have low mass per unit area (an upper limit of $12.2 \mathrm{~kg} / \mathrm{m}^{2}$ in NFPA, 1994) to decrease inertia so the time to open is kept short. The panels also generally open at lower pressures while in service than the pressures used in static tests (Dainty et al., 1990), presumably due to the impact pressure loading of deflagrations. The static test pressure variance was on the order of plus or minus $10 \%$, but the 53 deflagration tests performed on panels in Canada (Dainty et al., 1990) showed that the panels uniformly opened at lower pressures than the design pressure (3.4 $\mathrm{kPa}$ differential pressure), which is safety conservative for this equipment. Another design issue for panel reliability the NFPA (1994) guidance that the panels must be able to withstand the effects of wind pressure loading (if exterior panels), 
or the effects of wind suction pressure when the panels are mounted inside a stack. Lees (1980) cautions that explosion pressures can only be vented via short ducts, or else the room pressure will not be dissipated and will still damage equipment. Steam overpressures should be much less energetic than explosions, so moderate length ducts should be feasible.

Panel leakage failure rates are assumed to be similar to gasket leakage failure rates, since gaskets or similar types of seals will be used on these panels. A flange gasket leakage failure rate is 1E-07/hour, and rupture (large leakage) is 1E-09/hour, both with an error factor of 10 (Blanton and Eide, 1993, page 26). For the present time, these failure rates will be applied to panel small leakage and large leakage. These should be conservative values since the operating pressures from the Blanton and Eide data are higher than the small differential pressure that these panels normally encounter. If this possible failure mode becomes a larger concern, then these assumed failure rates can be revisited.

A concern for vent panel operation is that the pumping room might operate at a slightly elevated temperature. Fission power plant containment building air temperatures have been seen to vary between $27 \mathrm{C}(80 \mathrm{~F})$ to $87 \mathrm{C}(190 \mathrm{~F})$, with averages of about $38 \mathrm{C}$ (100 F) (Guyer et al., 1982). The panels and gaskets must be chosen for their durability in such elevated temperatures.

Ducts. These ducts are actually stainless steel piping rather than the typical rectangular sheet metal ducts used in industrial, commercial, and residential ventilating systems. The typical piping failure rates found in the literature can be applied to the ducts. Also, if piping is used for ductwork, then there are no louvers or dampers; instead there are valves. The valve failure rates can also be used from the literature. Suggested data sources for piping and valves are IAEA (1988), Eide and Calley (1993), Blanton and Eide (1993), and others. The piping leakage failure rates are on the order of $1 \mathrm{E}-10$ to $1 \mathrm{E}-11 / \mathrm{m}$ hour. Leakage from a duct would cause possibly radioactive tritium and activated corrosion products to exit into other areas of the building, unless the ducts are housed in some sort of tunnel, channel, well, or other secondary barrier, possibly made using building walls. This is a consideration for plant design, unless the ducts and valves are routinely inspected for integrity, or perhaps double walled piping and valves could be used.

Gas scrubbers. Scrubbers remove liquid droplets or solid particulates from a gas stream. There are several kinds of scrubbers - gravity settlers, cyclones, bubblers, venturi units, mechanical impact (such as wire mesh screens), and others. The general design of a scrubber is either wet or dry - that is, the scrubber either uses water (or other liquid) to help cleanse the gas stream, or uses some other means to perform separation. Dry scrubbers might be gravity settling, wire mesh, bag filtration, or electrostatic precipitation. Wet scrubbers are usually cyclone, venturi, or bubbler units. Cyclone 
scrubbers are composed of a cylindrical tank and an axial pipe. The gas stream enters at the bottom of the tank through a duct that directs the flow to begin to move in a circular helical pattern in the cylindrical tank. The gas stream is sprayed with water from nozzles in the axial pipe. The water and products that the water removes then travel to the walls, and gravity causes them to flow down to a collection drain at the bottom of the tank. The venturi scrubber operates in this manner: a pipe carrying the process gas leads to an orifice or venturi section. Some liquid (perhaps water or some liquid chemical that reacts with the material to be removed; but usually water) is added in the venturi for mixing with the process stream. This mixture empties into a tank for mixing with liquid in the tank and for settling. Usually, a second unit is needed to increase the cleansing efficiency. Therefore, an exit pipe from the tank leads the gas to a second venturi. The process is repeated with the second venturi and another tank. The outlet of the second tank is filtered to keep any of the injected liquid in the second tank (Fthenakis, 1993). The venturi scrubber has a definite pressure drop associated with it. Another type of wet scrubber is a bubbler, where the process gas-liquid mixture is bubbled up from the bottom of a tank filled with another liquid. Particulates within the bubbles mix at the bubbleliquid interface and are cleansed from the gas stream. More complete descriptions are given by Calvert et al. (1972). Klimczak (1998) addresses the efficiency of several types of scrubbers; wet cyclones 'collect well' for particles above two microns, wet venturi units can collect up to $99 \%$ of particles above one micron. Many industrial plants and grain-milling plants use wet scrubbers to clean the particulates from gas streams, and coal-fired power plants often use wet scrubbers to remove sulfur oxides from the flue gas and dry scrubbers (electrostatic precipitators, bag houses, etc.) to remove fly ash from the flue gases generated by burning coal (Culp, 1979). The wet scrubber is probably the most widely used in a variety of industries (El-Wakil, 1984). For fusion, the scrubber would not vary from those already in industrial use.

Some scrubber failure modes and rates have been found in the literature. Unfortunately for our application, these industrial units are operated in steady state, so the failure rates are all hourly values. The scrubbers for fusion would be operated as standby equipment with on startup demands, and the scrubbers would operate only for short hourly times. We shall decompose the scrubber unit into those components that must function on demand to estimate a demand failure rate for the unit.

Reported failure modes for industrial scrubbers are used to incorporate any failure mode contributions to the failure to start on demand failure rate. The main mechanisms mentioned in the literature cited above are corrosion, foreign material buildup, nozzle wear, and vibration (see also Bloss, 1979).

Blanton and Eide (1993) give a scrubber failure rate of 1E-06/hour for failure to function, with an error factor of 10. The type of scrubber is not discussed, but it is probably a wet cyclone type. They also give a mist eliminator (woven wire screen dry scrubber) failure rate of $1 \mathrm{E}-04$ per hour for failure to function, with an error factor of 10 . 
Other sources give wire mesh baffle scrubber failure rates between $5 \mathrm{E}-06$ to $1 \mathrm{E}-05 /$ hour (OREDA, 1992) for critical faults that require repairs, and the wet scrubber failure rates climbed up to about 6E-05/hour (Derdiger et al., 1981) for coal plant applications. The average wet scrubber failure rate is about $8 \mathrm{E}-06 /$ hour for the two given sources, with an error factor of about 10 . The average of these three wire mesh dry scrubber failure rates is about 1E-05/hour, so this value will be used as an estimate for a wire mesh scrubber in a fusion design. Some reported pressure drops for wire mesh are on the order of 75 to $150 \mathrm{~Pa}$ at gas flow rates of about $3 \mathrm{~m} / \mathrm{s}(\mathrm{CEH}, 1973)$. Other scrubbers, such as venturi units, also have pressure drop information (CEH, 1973, page 18-91) based on the size of the unit.

For scrubber failure on demand, the failure rate depends on the type of unit. If it is a cyclone scrubber with water injection, then any louver or isolation valve - there might not be a valve - must open and the water pump must turn on (and there must be a water supply). This is also true for venturi scrubbers. If the scrubber is a simple wire mesh (or woven wire screen) in a pipe or tank, then there should not be any failure rate on demand, only the hourly failure rates of failing to filter (broken through) or plugging (foreign material deposition, etc.). Pump failure to start on demand is in the $7 \mathrm{E}-02$ to $3 \mathrm{E}-03$ range (see Boardman, 1994; and Blanton and Eide, 1993, page 19). A failure rate of 1E-02 per demand is a reasonable order-of-magnitude failure rate to use for the scrubber unit starting up until more is known about the specific scrubber design for ITER. The water supply is assumed to be continuously available, although there might be an availability value associated with the water supply. There might not be a normally closed scrubber isolation valve in the system, so none will be accounted for here. With these assumptions about a reliable water supply and no valves that must open, the scrubber failure to start on demand value is $1 \mathrm{E}-02$. Another potential problem to consider is that the stack does not allow a backflow of cold atmospheric air to contact the wet scrubber, or the water might start to freeze. Also, the scrubber would have reduced efficiency if it is cleaning up dust and other debris (animal nests, leaves, etc.) that enter from the stack. Foreign material intrusion would degrade scrubber effectiveness, or even damage the unit so that it could not operate any longer.

Another scrubber that might be considered is the passive gravel bed scrubber (Muhlestein and Hilliard, 1982; McCormack et al., 1982). This scrubber is said to have the advantages of good collection efficiency, passiveness (no electricity needed to operate it), modest pressure drop ( $9 \mathrm{kPa}$ in small units), and high $\mathrm{kg} / \mathrm{m}^{2}$ particulate loadings. Blanton and Eide (1993) give sand filter failure rates of 3E-06/hour for plugging, 5E-07/hour for internal rupture, and 3E-06/hour for internal leakage. All three of these values have an error factor of 10. The sand filter is similar to a gravel bed scrubber, so these failure rates will be applied to gravel beds for the time being, until such time that more research is needed to find data on actual gravel bed units.

Air dryers. Drying air is similar to drying steam. In steam drying, the equipment units 
typically use either the passive 'tortuous path' to have moisture impact and adhere onto chevrons, or active refrigeration coils that cool the air or process gas so that water vapor will condense out of the gas stream. In either case, the condensate is usually channeled away using gravity flow. In a fission power plant, a passive steam dryer might be called a moisture separator, to remove liquid droplets from steam. In the fission power plant, droplet removal might be performed by a chevron baffle, a swirl vane cyclone, or other means (El-Wakil, 1978). In a coal-fired power plant, steam and water might be separated by gravity or buoyant forces in a steam drum at the top of the boiler, or, in higher power units, cyclone separators might be used (Baumeister et al., 1978). A large steam flow rate might be over $5 \mathrm{E}+05 \mathrm{~kg} /$ hour. Neither the gravity or cyclone separation units would use condensation, since that would tend to decrease the temperature of the steam, and the high flow rates would not allow adequate time for condensation to take place.

Refrigeration is an alternative to mechanical separation, and could work well for lower flow rates. However, refrigeration is an active means to take water droplets from steam or air. Blanton and Eide (1993) give a air conditioner/air cooler failure to start at 1E-02/demand, and failure to run at 3E-05/hour, both with an error factor of 10 . If ITER or another fusion design seeks passive cleanup, then a refrigerator or chiller is not the best means for this task. Wet scrubbers are simpler, do not use freon or any other chlorofluorocarbon, and can remove tritium or tritium oxide (see Chamberlain and Eggleton, 1964). Mechanical means, such as cyclones and chevron baffle plates, can remove nearly all water droplets from nuclear power plant steam flows to yield steam of very high quality, over $99.5 \%$ dry.

It might be possible (although perhaps not the best engineering choice available) to use a desiccant if the steam flow rate is reduced by an expansion area and there is a very large amount of desiccant arrayed with a very high surface area. This method of using chemical adsorbent beds is generally only used when refrigeration or cooling cannot attain the required dryness (Cremer and Watkins, 1963). There is a cited failure rate for desiccant of 6.6E-05/hour (NPRD, 1991) for a "charge" of this material, but the volume of a charge is not known. Unless already laden by atmospheric humidity or poisoned by foreign materials (compressor or pump oil, etc.), then the molecular sieve desiccant should be able to reliably function on demand. A demand failure rate would have to be evaluated when a specific design is known, including the valving arrangements to route steam flow into various desiccant tanks. A significant problem with the desiccant, besides the large sizes needed and cost, is waste disposal after the steam absorption event.

Filters. The high efficiency particulate air (HEPA) filter is designed to remove $99.97 \%$ of particulates of 0.3 micron and larger diameter (29CFR, 1997). These filters are used extensively in nuclear applications. Some work from the 1980's suggests that there is a significant problem with high humidity on these HEPA filters (Ricketts et al., 1986), including pleat tearing and high differential pressure from water loading. Later work by Osaki and Kanagawa (1989) and Rudinger et al.(1990) seems to indicate that filter 
susceptibility to humidity depends on the filter material. The pleat material must be chosen carefully, not only for high humidity from the postulated loss of coolant accident (LOCA) events, but also from a fire safety standpoint if a bearing overheat/lubricating oil or electrical insulation fire starts in the pump equipment room, it is conceivable that the room pressure will rise to the pop-out panel setpoint and combustion products, hot gases (probably 100's of degrees Celsius hotter than the steam from a LOCA), and possibly steam from fire suppression equipment (if water is used), could be transported to the filters depending on the placement of the filters in the ducts. Some filter materials cannot withstand combustion product gas temperatures (IAEA, 1987, page 83), so this concern is added to the caution in choosing filter materials.

There is a wealth of operating experience with HEPA filters that can be used to advantage when designing new systems. HEPA filters might have normal pressure drops of 400 to $2000 \mathrm{~Pa}$, but with humidity, the pressure drop generally rises while the decontamination factor decreases (Osaki and Kanagawa, 1989). Prefilters have normal pressure drops of $100-300 \mathrm{~Pa}$ for typical flow rates, and pressure drops for laden prefilters increase by factors of 3 to 5 (IAEA, 1987). The IAEA (1993), the US Nuclear Regulatory Commission (NRC, 1979), and the US Department of Energy (Burchstead et al., 1976) also have design and operation guidance for gas handling systems. Moeller (1975), Moeller and Sun (1983), and Carbaugh (1981) have reported on operating experiences with these filters. These experiences can support designers in future design efforts.

HEPA filter failure rates have been estimated to be between 1E-08/hour (all modes) (Dexter and Perkins, 1982), 3E-06/hour (plugging and leakage) and 5E-07/hour for rupturing (Blanton and Eide, 1993). The latter failure rates have an error factor of 10. All of these values refer to normal operating filters, not filters in severe conditions. Failure rates could increase by a factor of 10 or more for severe conditions. The demand failure rate is expected to be very low for these filters, unless the panels that isolate the filters are leaking past, or foreign material becomes laden on the filter from the stack itself. Panel leakage would depend on the operation of the building, such as keeping the pump rooms maintained at slightly subatmospheric pressure. Regular inspection of the filters would help ensure that they could function on demand.

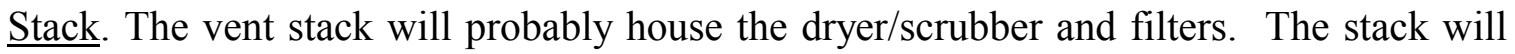
not have any active components, such as fans, to drive the steam outward, only the pressure of the steam will drive the cleanup equipment. Therefore, the stack reliability is composed of plugging, leakage, and structural failure considerations. Stack plugging can, and has, happened. One stack-related event at a nuclear power plant was very hazardous in 1976 ice plugged the stack of an off-gas handling building (Bertini, 1980), causing the hydrogen gas to back up into the building. The hydrogen detonated in air. The off-gas handling building was demolished and had to be rebuilt. The stack was also rebuilt and heaters were mounted in the stack to prevent ice formation. While ITER steam cannot 
detonate, the stack can still be plugged by ice, or a bird nest, etc. Covers to preclude ice or animal encroachment would also cause flow friction, which will be very detrimental in the natural flow system proposed for passive steam venting in loss of coolant events. Perhaps stack heaters would be useful if the facility is constructed in a climate that makes ice buildup a concern. Considering stack plugging, the single event discussed above is the only known occurrence over about 1500 reactor-years of US fission reactor operations, so the frequency would be about $6 \mathrm{E}-04$ per year, or less than $1 \mathrm{E}-07 /$ hour. Combining stack plugging [the time of interest for the stack to be plugged should be less than 168 hours, a liberal estimation of the duration of a steam venting accident] with the frequency of a loss of coolant accident makes the stack being plugged during that event a beyond design basis event (that is, a combined frequency of less than 1E-06/year).

Another plugging issue, liner movement, must be addressed when stack details are known. In some stacks, a liner of brick is used, and it has been noted at coal-fired power plants that the liner bricks can begin to lean (Makansi, 1985; Bretz, 1989). This liner swelling or leaning could lead to reduced flow area and possibly reduction in flow out the stack. Metal plate liners could also warp or swell. The construction details will have to be reviewed to determine if the plugging failure rate given above applies to the stack design.

Stack leakage is also important. Assuming that the stack will have some type of liner, the leakage should have a very low failure rate. If the liner in the stack is a continuation of the piping duct, then the pipe leakage failure rates apply. Blanton and Eide (1993, page 20) give a pipe leakage failure rate of 3E-09 per hour-foot, with an error factor of 10 . This failure rate is roughly $1 \mathrm{E}-08 /$ hour-meter. If the stack is $100 \mathrm{~m} \mathrm{high}$, then the stack leakage failure rate is $1 \mathrm{E}-06$ per hour of use. This failure rate gives a very low probability of leakage over a week.

Stack structural reliability is another consideration. For frame structures, with safety factors between 1.5 and 2.0, the probability of failure over the life of the structure can be between 1E-03 to 1E-04 (Rao, 1992). Other analysts have set an upper bound failure probability of 2.4E-04 over building life for frame structures (for the building experiencing only the expected service conditions; no beyond design basis events considered) and a lower bound limit of 1E-06 to 1E-08 (Cornell, 1967). For robust concrete structures such as the wails of a fission reactor containment building, the failure probability might be on the order of 1E-04 for high stress demands over the 40 year lifetime (Petrina et al., 1979), and a lower failure rate for random failures under nonstress conditions [this failure rate should be less than 1E-06]. The containment building penetrations were not considered in that study. The ITER stack structure (lifetime of 20 years) failure rate should lie in the 1E-04 range or lower over its life.

\subsection{Plasma Shutdown System}


A plasma shutdown system would be needed to maintain integrity of in-vessel tubing when there is a cooling pipe break inside, or more importantly, outside the tokamak machine. In the external LOCA cases, the event leads to the in-vessel tubes being burned out in short time frames $[<60 \mathrm{~s}$ of continued plasma operation (see Marshall et al., 1994)], and this is a situation where the radioactive inventories in the vessel (tritium, dust, plasma disruption volatilized materials from the walls, and possibly water chemical reaction volatilized materials from the walls) can escape after air pressure equalization. The details of the plasma shutdown system are not defined at this time. The system would probably be a disruption inducing system, and that could be gas puffing, heavy pellet injection, controlled poloidal field plasma collapse, cryogenic gas (e.g., nitrogen) pellet injection, or some other approach.

For the present time, an estimate of the reliability on demand of such a system to operate is needed. In the future, when the system is better defined, then an estimate of the system's effectiveness in producing a controlled plasma shutdown in the required time frame will need to be made. For now, we shall assume that the effectiveness is $100 \%$, since there is no way to adequately judge a system that is not yet defined.

This system will be a safety system. Its function is to control and terminate the fusion plasma in a timely manner (assume $<1 \mathrm{~s}$ actuation time is required) during offnormal events, before the in-vessel tubes breach and allow water into the plasma chamber. The system should be required to have sensor redundancy and voting logic to greatly reduce, or preclude, inadvertent actuations. The voting logic is essential because unwanted plasma disruptions erode wall materials faster than expected; the fewer disruptions then the longer the wall material will last. Also, and perhaps more importantly, the disruptions put stresses (thermal and mechanical) onto the vacuum vessel, so avoidance of unnecessary stresses is conducive to vacuum vessel longevity. Therefore, the plasma shutdown system must be a high technology, fast-acting system with electrical sensor inputs, redundancy, voting logic, and most likely, mechanical parts (gas valves, pellet injector, etc.). These features make the plasma shutdown system similar to other safety systems at other types of nuclear and industrial facilities.

In reliability prediction work, there is a practice where known failure rates from one kind of component are applied to another component of similar type in similar conditions; this transfer is called the 'Similar Item Method' in MIL STD-756B (1981). Simple applications of this method would be using the same failure rate for the same type of small component - a resistor or capacitor - in slightly changed voltage or electrical current conditions, or applying the reliability results of one kind of electronic circuit to a similar one. Other applications of the similar item method prediction technique - with much less confidence -would be applying system level failure rates or availability to similar systems. Since so little information is known about the plasma shutdown system, at this time we must assume reliability from similar systems instead of perform fault models, such as a fault tree, directly on the system. Given the description above, then the 
most similar system is a fission reactor "scram" shutdown system, with failure rates varying between 4E-04 (Winfield, 1993), 1E-04 (Oh et al., 1990), 3E-05 (Cadwallader and Piet, 1989), to about 5E-06 per demand (Kamal and Hill, 1993). The Sizewell plant in the UK has had 60,000 tests run on its digital control scram system, without failure (Boettcher, 1994), which gives a failure rate bound on the order of 1E-05 per demand. Green (1983) states that with common cause considerations, that a failure rate of 1E-06 per demand is a practical lower limit for protective system reliability, and if the system is clustered or contained in one room, then $1 \mathrm{E}-04$ is a more appropriate lower reliability limit to be achieved.

Therefore, for the present time, a 1E-04/demand is conservatively assumed as a value for the plasma shutdown system functioning, and we shall assume a very high error factor of 30 because of the judgments involved here and potential variation in the fission to fusion system comparisons. We shall also assume $100 \%$ system effectiveness (that is, if the system actuates correctly, then the plasma will shut down) until more is known about the system to judge its plasma shutdown effectiveness. The failure rate of 1E-04 per demand seems to be reasonable, given that the published values for scram systems varied by almost two orders of magnitude, and we are conservatively choosing from the higher end of that data spread. Perhaps ITER can take advantage of newer digital technology evidenced at the Sizewell B fission power plant.

\subsection{Vacuum Vessel Pressure Suppression Rupture Disks}

The ITER vacuum vessel plasma chamber design called for a pressure suppression system. This system might be a small toroidal chamber, similar to the pressure suppression pool systems found on boiling water reactors, or a set of small tanks around the vacuum vessel. While most of the system is simply piping and a torus-shaped tank, there is one component of great interest. This component is a burst disk (or rupture disk) that seals between the vacuum chamber and the suppression pool. The burst disk must routinely seal against high vacuum on one side (perhaps $1 \mathrm{E}-05 \mathrm{~Pa}$ ) and the saturation pressure of water at $20 \mathrm{C}$ (about $2600 \mathrm{~Pa}$ ) on the other side.

The burst disk must operate when the vacuum chamber pressure increases past $2600 \mathrm{~Pa}$. There are two failure modes of concern for the burst disk. The first is that it may not function when required, and the second is that it may leak water vapor into the vacuum chamber. Burst disks are generally fragile, since they must have thin walls to respond quickly to pressure changes. Therefore, these units will probably have valves to isolate them from the vacuum chamber when ITER is not in plasma operations. For example, during remote maintenance or bakeout operations, the rupture disks might be valved out with large gate valves. Isolation for inspection and maintenance is required in other industries that use rupture disks (API, 1993).

There are some failure rate data about rupture disks in the literature. The units 
reported on are generally sealing with atmospheric pressure on one side, and higher process pressure on the other side. When the process pressure undergoes an excursion, then the burst disk opens to relieve the pressure. Most disks operate to guard against the high pressure side having overpressure, not the low pressure side having overpressure. This does not mean that such a burst disk cannot be built, in fact the reverse-buckling type might be optimal for this application, but the existing failure rate data may not be strictly applicable to the envisioned ITER burst disks.

Dexter and Perkins (1981) gave a rupture diaphragm (25.4 to $40.6 \mathrm{~cm}$ diameter) failure rate of 6.49E-06/hour, presumably for leakage. Melvin and Maxwell (1974) give a failure rate for rupture disk assemblies of $1 \mathrm{E}-07 /$ hour, with an error factor of about 3 . An IAEA report (1988, page 159) gave 3.3E-06/hour for 25.4 to $40.6 \mathrm{~cm}$ diameter rupture disks. Lees (1980, page 1009) gives a failure rate for bursting disks rupturing at normal pressure of 0.2 year, or 2.3E-05/hour. The NPRD (1991) report gives a burst diaphragm (used in a fixed ground location for the military) upper bound failure rate of $1.4 \mathrm{~B}$ 06/hour. The type of rupture disk is not given in any of these reports. Therefore, for a generic rupture disk failure rate, we shall use the geometric mean of $2 \mathrm{E}-06 /$ hour. Disk failures can be the result of corrosion, fatigue weakening by pressure pulses near but below the burst pressure, pinhole material flaws, thermal cycling stresses, damage due to dents, knicks, or other results of improper installation, dull or dirty knife edges (if the knives are employed as the bursting tool), and other mechanisms. This leakage failure rate will probably not be very attractive for water vapor leakage into the vacuum chamber, depending on the number of rupture disks needed. If this is true, then it is possible to also use a very thin membrane of metal (perhaps aluminum) or a polymer that might help reduce water vapor contact on the suppression torus side of the disk. Polymer membranes ( $0.8 \mathrm{~mm}$ thick butyl rubber) service lives in outdoor water management use have been noted to be on the order of 20 to 25 years without leakage, and other polymer membranes of similar thicknesses in environments of harsh chemical waste disposal environments (caustics, oils, pesticides, etc.) have had lives of 4.5 to 5 years or greater (Haxo et al., 1984). These membranes would not have any structural strength to oppose the flow of $0.5 \mathrm{MPa}$ steam from the vacuum chamber, but merely to keep suppression pool water vapor from contacting the rupture disk.

For rupture disks not opening when required, there is little published information. One estimate of 1E-04/demand is reported in Cadwallader and Piet (1989). This value seems reasonable, since the rupture disk is a simple component and it is intended to be the weakest part of the wall area in a system, and the literature suggests that it generally will rupture close to its bursting pressure. This failure rate is comparable to the explosion panel failure rate, and since these two types of devices serve similar purposes, the 1E04/demand rate is acceptable. Considering that many safety relief valves have 'failure to open on demand' rates in the 1E-03 range, then it is reasonable that the simpler rupture disk should have a lower failure rate. An error factor of 10 is assumed for the rupture disk failure rate, since the failure rate was based on engineering judgment rather than 
accumulated service data. Rupture disks are required to be able to burst within $\pm 5 \%$ of the design burst pressure (Nazario, 1988; API, 1993), but many are noted to burst within $\pm 2 \%$ of the design burst pressure (Wood, 1965). The hydraulic design of the rupture disks and the vent piping is a large safety concern, and must be approached with attention (Huff and Shaw, 1992; Perbal, 1993). Design, application, and installation information on rupture disks is published by the chemical industry (API, 1990; API, 1993).

For ITER, the number of disks will probably depend on the port sizes available. There are published means to determine the rupture disk area (Nazario, 1988; API, 1993) and guidance to provide conservatism, such as using the ambient temperature for rupture disk calculations instead of the higher process temperature. One important item to note is that the rupture disks will not tolerate the vacuum vessel bakeouts very well. Also, since rupture disk design practices call for isolation valves to allow inspection and replacement (API, 1993), then perhaps these isolation valves can be closed during system bakeouts to protect the disks from the $300 \mathrm{C}$ bakeout temperatures.

Table 1 presents the data that was discussed in this chapter. 
Table 1. Safety System Component Failure Rates

\begin{tabular}{|c|c|c|c|}
\hline Component & Failure mode & Failure rate & Error factor \\
\hline blow-out panels & fail on demand & 1E-03/demand & upper bound \\
\hline blow-out panels & leakage & 1E-07/hour & 10 \\
\hline blow-out panels & rupture & 1E-09/hour & 10 \\
\hline vent duct & leakage & 1E-11/m-hour & 10 \\
\hline wet gas scrubber & fail to operate & 8 E-06/hour & 10 \\
\hline wet gas scrubber & fail to start & 1E-02/demand & upper bound \\
\hline wire mesh scrubber & fail to function & 1E-05/hour & 10 \\
\hline gravel bed scrubber & plugging & 3E-06/hour & 10 \\
\hline gravel bed scrubber & internal rupture & 5E-07/hour & 10 \\
\hline gravel bed scrubber & internal leakage & 3E-06/hour & 10 \\
\hline $\begin{array}{l}\text { air dryer } \\
\text { (refrigeration) }\end{array}$ & fail to start & 1E-02/demand & 10 \\
\hline $\begin{array}{l}\text { air dryer } \\
\text { (refrigeration) }\end{array}$ & fail to operate & 3E-05/hour & 10 \\
\hline HEPA filter & plugging & 3E-06/hour & 10 \\
\hline HEPA filter & leakage & 3E-06/hour & 10 \\
\hline HEPA filter & rupture & 5E-07/hour & 10 \\
\hline stack & leakage & 1E-08/hour-m & 10 \\
\hline stack & structural failure & 1E-04/stack lifetime & upper bound \\
\hline $\begin{array}{l}\text { plasma shutdown } \\
\text { system }\end{array}$ & fail on demand & 1E-04/demand & 30 \\
\hline rupture disk & leakage & 2E-06/hour & 10 \\
\hline rupture disk & fail on demand & 1E-04/demand & 10 \\
\hline
\end{tabular}




\section{Chapter 2 References}

API, 1990.

API, 1993.

Baumeister et al., 1978.

Bertini, 1980.

Blanton and Eide, 1993.

Bloss, 1979.

Boardman, 1994.

Boettcher, 1994.
American Petroleum Institute, Guide for PressureRelieving and Depressuring Systems, API Recommended Practice 521, third edition, November 1990.

American Petroleum Institute, Sizing, Selection. and Installation of Pressure Relieving Devices in Refineries, Part I - Sizing and Selection, API Recommended Practice 520, sixth edition, March 1993; and Part II - Installation, third edition, November 1988.

T. Baumeister et al., Mark's Standard Handbook for Mechanical Engineers. eighth edition, McGraw-Hill Book Company, New York, ISBN 0-07-004123-7, 1978, page 9-28.

H. W. Bertini, Descriptions of Selected Accidents that have Occurred at Nuclear Reactor Facilities, ORNL/NSIC-176, Oak Ridge National Laboratory, April 1980, pages 67-68.

C. H. Blanton and S. A. Bide, Savannah River Site Generic Data Base Development (U), WSRC-TR93-262, Westinghouse Savannah River Company, June 1993, page 35.

H. E. Bloss, "A Basic Guide to Upgrading Scrubber Performance," Plant Engineering, 33, December 13, 1979, pages 73-75.

J. R. Boardman, Operating Experience Feedback Report - Reliability of Safety-Related Steam Turbine-Driven Standby Pumps, NUREG-1275, volume 10, US Nuclear Regulatory Commission, October 1994, page 18.

D. Boettcher, "State-of-the-art at Sizewell B," ATOM, Number 433, March/April 1994, pages 3443. 
Bretz, 1989.

Burchstead et al., 1976.

Cadwallader and Piet, 1989.

Calvert et al., 1972.

Carbaugh, 1981.

CEH, 1973.

Cornell, 1967.

Chamberlain and Eggleton, 1964.

Cremer and Watkins, 1963.

Culp, 1979.
E. A. Bretz, "New Operating Modes Broaden Quest for Stack Liner Materials," Power, 133, September 1989, pages 57-60.

C. A. Burchstead et al., Nuclear Air Cleaning Handbook, ERDA 76-21, US Energy Research and Development Administration, 1976.

L. C. Cadwallader and S. J. Piet, 1989 Failure Rate Screening Data for Fusion Reliability and Risk Analysis, EGG-FSP-8709, EG\&G Idaho, Inc., September 1989.

S. Calvert et al., Scrubber Handbook, Air Pollution Technology, Inc., San Diego, CA, US National Technical Information Service report number PB213-016, 1972.

B. H. Carbaugh, A Survey of HEPA Filter Applications and Experience at Department of Energy Sites, PNL-4020, Pacific Northwest Laboratories, 1981.

Chemical Engineer's Handbook. fifth edition, edited by R. H. Perry and C. H. Chilton, McGraw-Hill Book Co., New York, ISBN 0-07-049478-9, 1973, p. 18-86.

A. C. Chamberlain and A. B. J. Eggleton, "Washout of Tritiated Water Vapor by Rain," International Journal of Air and Water Pollution, $\underline{8}, 1964$, pages 135-149.

C. A. Cornell, "Bounds on the Reliability of Structural Systems," Journal of the Structural Division of the ASCE, 93, February 1967, pages 171-200.

H. W. Cremer and S. B. Watkins, editors, Chemical Engineering Practice, Volume 7, Heat Transfer, Academic Press, New York, 1963, pages 451-453.

A. W. CuIp, Jr., Principles of Energy Conversion, McGraw-Hill Book Company, ISBN 0-07-0148929, 1979, chapter 6 . 
Dainty et al., 1990.

Derdiger et al., 1981.

Dexter and Perkins, 1982.

Eide and Calley, 1993.

El-Wakil, 1978.

El-Wakil, 1984.

Fthenakis, 1993.

Green, 1983.

Guyer et al., 1982.
B. B. Dainty et al., Performance Testing of Explosion Relief Panels Manufactured by $\mathrm{C} / \mathrm{S}$ Construction Specialties Limited, MRL 90-020, Canada Centre for Mineral and Energy Technology, Mining Research Laboratory, Ottawa, Ontario, 1990.

J. A. Derdiger et al., Component Failure and Repair Data for Coal-Fired Power Plants, EPRI AP-2071, Electric Power Research Institute, October 1981, page 2-40.

A. H. Dexter and W. C. Perkins, Component Failure-Rate Data with Potential Applicability to a Nuclear Fuel Reprocessing Plant, DP-1633, Savannah River Laboratory, July 1982.

S. A. Eide and M. B. Calley, "Generic Component Failure Data Base," PSA '93. Proceedings of the International Topical Meeting on Probabilistic Safety Assessment, Clearwater Beach, Florida, January 26-29, 1993, pages 1175-1182.

M. M. El-Wakil, Nuclear Energy Conversion, American Nuclear Society, La Grange Park, Illinois, ISBN 0-89448-015-4, 1978, chapters 4, 5.

M. M. El-Wakil, Powerplant Technology, McGraw Hill Book Company, New York, ISBN 0-07019288-X, 1984, chapter 17.

V. M. Fthenakis, Prevention and Control of Accidental Releases of Hazardous Gases, Van Nostrand Reinhold, New York, ISBN 0-442-004893, 1993, page 442 .

A. E. Green, Safety Systems Reliability, John Wiley \& Sons, Chichester, ISBN 0-471-90144-X, 1983, page 85 .

E. C. Guyer et al., Control of Containment Air Temperature: An Industry Survey and Insulation Test, EPRI NP-2694, US Electric Power Research Institute, October 1982, chapter 2. 
Haxo et al., 1984.

Huff and Shaw, 1992.

IAEA, 1987.

IAEA, 1988.

IAEA, 1993.

Kamal and Hill, 1993.

Kilmczak, 1998.

Lees, 1980.

Makansi, 1985.

Marshall et al., 1994.
H. E. Haxo, Jr. et al., Liner Materials Exposed to Hazardous and Toxic Wastes, EPA/600/2-84/169, US National Technical Information Service number PB85-121333, US Environmental Protection Agency, November 1984, pp. 54, 107, 111.

J. E. Huff and K. R. Shaw, "Measurement of Flow Resistance of Rupture Disc Devices," Plant/Operations Progress, 11, July 1992, pages 187-200.

Design of Off-Gas and Air Cleaning Systems at Nuclear Power Plants, IAEA Technical Report 274, International Atomic Energy Agency, Vienna, 1987, page 47 .

Component Reliability Data for Use in Probabilistic Safety Assessment, IAEA-TECDOC-478, International Atomic Energy Agency, Vienna, 1988.

Off-Gas and Air Cleaning Systems for Accident Conditions in Nuclear Power Plants, IAEA Technical Report 358, International Atomic Energy Agency, Vienna, 1993.

S. A. Kamal and D. J. Hill, "Fault Tree Analysis of the EBR-II Reactor Shutdown System," PSA '93. Proceedings of the International Topical Meeting on Probabilistic Safety Assessment, Clearwater Beach, FL, January 26-29, 1993, pages 754-762.

W. Klimczak, "Dust Collector Selection," Chemical Processing, Powder and Solids Annual, 1998.

F. P. Lees, Loss Prevention in the Process Industries, Butterworth Hienemann Ltd, Oxford, ISBN 0-7506-1529-X, 1980, page 625.

J. Makansi, "Check for "Leaning" Stack Liners," Power, $\underline{129}$, May 1985, pages 56-57.

T. D. Marshall et al., Time-To-Burnout of an ITER Divertor Tube During a Loss of Flow Accident, US Home Team engineering design file 
McCormack et al., 1982.

Melvin and Maxwell, 1974.

MIL-STD 756B, 1981.

Moeller, 1975.

Moeller and Sun, 1983.

Moore, 1989.

Muhlestein and Hilliard, 1982.

Naidus, 1981.

Nazario, 1988.
ITER/US/94/FE/DV-1, Sandia National Laboratory, December 5, 1994.

J. D. McCormack et al., Testing of a Passive Submerged Gravel Scrubber for Containment Venting Applications, HEDL-5A2637 FP, CONF820833-11, Hanford Engineering Development Laboratory, August 1982.

J. G. Melvin and R. B. Maxwell, editors, Reliability and Maintainability Manual, Process Systems, AECL-4607, Chalk River Nuclear Laboratories, January 1974.

Military Standard, Reliability Modeling and Prediction, MIL STD 756B, US Department of Defense, November 18, 1981, page 2001-1.

D. W. Moeller, "Problems in Nuclear Air-Cleaning Systems," Nuclear Safety, 16, July-August 1975, pages 469-481.

D. W. Moeller and L-S. C. Sun, "Failures in AirCleaning, Air-Monitoring, and Ventilation Systems in Commercial Nuclear Power Plants, 1978-1981," Nuclear Safety, 24, May-June 1983, pages 352-371.

P. E. Moore, "Industrial Explosion Protection Venting or Suppression?," Hazards X: Process Safety in Fine and Specialty Chemical Plants Including Developments in Computer Control of

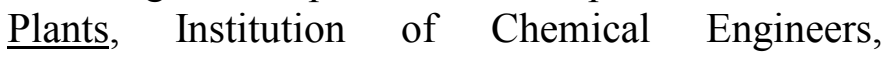
Symposium Series No. 115, Rugby, UK, 1989, pages 257-279.

L. D. Muhlestein and R. K. Hilliard, Air-Cleaning Devices for Vented Filtered LMFBR Containment, HEDL SA-2592, Hanford Engineering Development Laboratory, July 1982.

E. S. Naidus, "Full-Scale Explosion Study of Relief Vents Suitable for Protecting Large Structures," Loss Prevention, 14, American Institute of Chemical Engineers, 1981, pages 35-43.

F. N. Nazario, "Rupture Discs, a primer," Chemical 
Engineering, 93, June 1988, pages 86-96.

NFPA, 1994.

NPRD, 1991.

NRC, 1979.

Oh et al., 1990.

OREDA, 1992.

Osaki and Kanagawa, 1989.

Perbal, 1993.

Petrina et al., 1979.
National Fire Protection Association Standard 68, Guide for Venting of Deflagrations, US National Fire Protection Association, Quincy, MA, 1994, section 4.7.6.

W. Denson et al., Nonelectronic Parts Reliability Data, 1991, NPRD-91, Reliability Analysis Center, Griffiss Air Force Base, New York, 1991, page 211.

US Nuclear Regulatory Commission, Design, Testing and Maintenance Criteria for Normal Ventilation Exhaust System Air Filtration and Adsorption Units of LW Cooled Nuclear Plants, Regulatory Guide 1.140, revision 2, October 1979.

K. B. Oh et al., "Reliability Analysis of KMRR Safety and Process Systems," Proceedings of the International Topical Meeting on The Safety, Status and Future of Non-Commercial Reactors and Irradiation Facilities, Boise, Idaho, September 31October 4, 1990, pages 559-564.

OREDA, Offshore Reliability Data Handbook, second edition, BP Norway Limited and others, 1992, ISBN 82-515-0188-1, pages 48-53.

M. Osaki and A. Kanagawa, "Performance of High Efficiency Particulate Air Filters Under Severe Conditions," Nuclear Technology, 도, June 1989, pages 274-284.

K. Perbal, "Transient Flow Phenomena and Reaction Forces During Blowdown of Gas at High Pressures Through Relief Lines Behind Rupture Discs," Process Safety Progress, 12, October 1993, pages 232-239.

P. Petrina et al., Safety Analysis of Nuclear Concrete Containment Structures, NUREG/CR1097, US Nuclear Regulatory Commission, December 1979, pages 164-165. 
Rajagopalan and Camacho, 1989.

Rao, 1992.

Ricketts et al., 1986.

Rudinger et al., 1990.

Rust, 1979.

Winfield, 1993.

Wood, 1965.

29CFR, 1997.
R. Rajagopalan and F. Camacho, "Availability of the Pressure Relief Panel System at Pickering "A" Nuclear Generating Station," in V. Colombari, editor, Reliability Data Collection and Use in Risk and Availability Assessment, Proceedings of the 6th EuReData Conference, Siena, Italy, March 15-17, 1989, Springer-Verlag, Berlin, 1989, pages 548562.

S. S. Rao, Reliability-Based Design, McGraw-Hill Book Company, New York, ISBN 0-07-051192-6, 1992, page 344.

C. I. Ricketts et al., "HEPA-Filter Behavior Under High Humidity Airflows," Proceedings of the 19th DOE/NRC Nuclear Air Cleaning Conference, NUREG/CP-0086, May 1987, pages 3319-352.

V. Rudinger et al., "High Strength High-Efficiency Particulate Air Filters for Nuclear Applications," Nuclear Technology, 92, October 1990, pages 1129.

E. A. Rust, "Explosion venting for low-pressure equipment," Chemical Engineering, $\underline{86}$, November 15, 1979, pages 102-110.

D. J. Winfield, "Fault Tree Analysis of a Research Reactor Shutdown System," PSA '93, Proceedings of the International Topical Meeting on Probabilistic Safety Assessment, Clearwater Beach, Florida, January 26-29, 1993, pages 344-350.

L. E. Wood, "Rupture Discs," Engineering Progress, 61 , February 1965, pages 9396.

Title 29, "Labor", of the US Code of Federal Regulations, Part 1910, Occupational Safety and Health Standards, definitions section, July 1997. 


\section{VACUUM VESSEL COMPONENT FAILURE AND REPAIR RATES}

This chapter gives the basis for vacuum system component failure rate and component repair rate values developed for use in the ITER EDA. Since ITER is a first of a kind machine, there is little prior fusion operating experience data that can be applied. Therefore, data values are inferred from various sources of non-fusion operating experiences. The data gathered for fusion are not detailed enough to support statistical analyses, such as statistical distribution curve fitting. Appendix A has tables of these data values.

The failure rates are assumed to be adequately modeled by the exponential distribution, and they are assumed to be in the "bottom of the bathtub"; that is, in the nearly constant failure rate portion of their useful lifetime. Any early life failures are expected to be uncovered in pre-operational testing or in the initial period of operations with small power/small fluence. For the exponential distribution, if the product of the failure rate and the time are less than 0.1 , then the distribution can be closely approximated as simply the constant failure rate multiplied by the operating time, to give a constant yearly probability of component failure. Therefore, the failure rates are constant values with an upper bound given. The exponential distribution also possesses a quality referred to as 'lack of memory'; that is, the component does not remember how long it has been operating - it has a constant failure rate regardless of its power-on time (Tobias and Trindade, 1995). While this assumption may not be appropriate for all components, it is used quite often in risk assessment. While risk assessors and reliability engineers would like to have more data available, this is the extent of the data that exist for fusion components at the present time and for the near future.

Repair times are even less well defined than failure rates (Cadwallader, 1996). The individual factors at each plant or facility site make for wide variability in repair (accessibility, need for personal protective equipment, in-situ repair versus replacement, etc.). Institution-specific procedures and practices also impact the repair times (number of people on shift, availability of spare parts, logistics procedures, equipment lock out-tag out techniques, etc.). If the times are given in person-hours, then it is assumed that there is one maintenance crew member performing the type of repair. This assumption is made based on the practice that a crew consists of several people, but they would have a range of skills, such as mechanic, pipe fitter, electrician, instrument technician, etc., and usually only one crew member is active on a given task at a time. In practice, additional people could be called in to assist the lead crew member, but for this stage of the ITER design the assumption is conservative. The same constant value assumption is made for repair rates (probability of repair divided by the time of repair). The reciprocal of repair times

are used to obtain representative average repair rates for ITER components. Upper bounds are cited when they have been given in the source literature. 
Double Walled Vacuum Vessel. An early estimate of vacuum vessel wall integrity suggested the extremely unlikely events range of 1E-04 to 1E-06/year (Cadwallader, 1994). Considering a recent survey of pressure vessel failure rates shows an overall failure rate of 5.1E-05/year, with these failure mode distributions: inspection faults (57\%), leakage faults $(28.5 \%)$, wall deformation without breach $(10 \%)$, and disruptive failures (ruptures, 4.5\%) (Davenport, 1991).

Since ITER vessel walls are on the order of 30 to $40 \mathrm{~mm}$ thick steel, and since the maximum cooling water pressure between the two walls is about $3 \mathrm{MPa}$ (GDRD, 1995), there is no reason to expect that the walls will warp, bow, or otherwise deform. The walls are slightly cambered to allow thermal expansion only in predicted directions, and there is no mechanism recognized that would allow the two walls to approach each other or touch each other during normal operations. Electromagnetic loads on the vessel walls are accounted for in the design, with appropriate safety factors. The American Society of Mechanical Engineers (ASME) Boiler and Pressure Vessel (B\&PV) Code will be followed in the vacuum vessel design (GDRD, 1995), making it comparable in materials and design conservatism to the large set of pressure vessels operating in various industries. Failure rates for the vessel under plasma disruption stresses should be between 1E-03 to 1E-05 per demand (based on pressure vessel work by Gamble and Strosnider, 1981). The mid-range value of 1E-04/demand is judged to be appropriate and is used here, with an upper bound of 1E-03/demand.

Since leakage and rupture failures can occur from cracks in the materials, the failure modes of concern for the ITER vacuum vessel will be leakage and rupture. The failure modes based on the Davenport (1991) work are 87\% leakage and 13\% rupture distributions of the overall vessel failure rate of $1.7 \mathrm{E}-05 /$ year with a $95 \%$ upper bound of $2 \mathrm{E}-05 /$ year. Therefore, vessel leakage is $(0.87)(1.7 \mathrm{E}-05 / \mathrm{yr})=1.5 \mathrm{E}-05 / \mathrm{year}$, and rupture is $(0.13)(1.7 \mathrm{E}-05 /$ year $)=2 \mathrm{E}-06 /$ year. These failure mode distributions are very close to those cited by Thomas (1981), who suggested that on the order of $10 \%$ of leaks are ruptures. The vessel welds must be treated as well, since these are important and also numerous. Fullwood (1989) also supports the Thomas method.

Buende (1991) discussed weld reliability in fusion blankets, and these results are also valid for other welds. Buende states that using conventional weld technology will not give very high availability, and that advanced welding methods are needed for fusion reactors. Using Buende's input and assuming stringent quality control and electron beam welding gives a weld failure rate of 1.8E-07/hour-meter (Cadwallader, 1994), where meters denotes the meters of length of weld and hours denotes calendar hours. This failure rate is for small leaks; the failure rate for large leaks is a factor of 10 lower, and for weld ruptures the failure rate is a factor of 100 lower (Buende, 1991). The upper bound failure rate for small weld leaks is set at $2 \mathrm{E}-06 /$ meter-hour. If the welds are double welded with two complete welds per joint, then the failure rate can be reduced by a factor 
of 10, which is the same factor as applied to double walled piping (see Marshall and Cadwallader, 1994).

Repairs to the vacuum vessel would have to be handled by remote means. The vacuum vessel is a remote handling $(\mathrm{RH})$ class 3 component (GDRD, 1995), which means that it is a permanent structure with no remote repairs envisioned over its operating life. Considering the time for a divertor module or first wall module changeout is 8 weeks (GDRD, 1995), a weld repair to the vessel would be at least 16 weeks, the time to remove these two modules, perform the repair, test the repair, and reassemble the machine. Then the repair rate would be $[1 /(16$ weeks $)(168 \mathrm{~h} /$ week $)]=3.7 \mathrm{E}-04 /$ hour. The outer vessel wall welds may only be accessible from inside the vacuum vessel (i.e., cut open inner wall, remove shielding, perform weld repair, then replace the equipment). This repair might take much more time than 16 weeks, perhaps 32 weeks total repair time. The repair rate would be $[1 /(32$ weeks $* 168 \mathrm{~h} /$ week $)]=1.9 \mathrm{E}-04 /$ hour.

Vacuum vessel struts. These struts or ribs between the two walls of the vacuum vessel are steel, welded to the two walls. The failure rate for these components should be on the order of the vessel walls itself, 1E-05/year. Carter (1986) suggests that well made, simple mechanical parts would have an upper bound failure rate on the order of 9E-05/year, so this is a reasonable assumption. The weld failure rates will be the same as those for the vacuum vessel. Average repair times for these struts would be on the same order as the estimate for the vacuum vessel weld leakage repair, 32 weeks, or a repair rate of $1.9 \mathrm{E}-$ 04/hour.

The vessel inter-wall struts should behave well under vacuum vessel stress conditions, since they are designed to accept the stresses from electromagnetic loads in plasma disruptions, overpressure from coolant leaks, and thermal stresses from heat-up and cool-down. Failure rates for bracket components under thermal and mechanical accident stresses in fission reactor cores show failure probabilities of less than 1E-08 per demand (Staat, 1993).

Neutron shielding plate inserts. These radiation shields between the two walls of the vacuum vessel are largely passive components. These components function by maintaining their structure under conditions of possible corrosion and neutron bombardment. These metallic plates (steel or perhaps lead) will have a low failure rate. Metallic shielding generally has a low failure rate, not failing over the life of a facility (perhaps 50 years). With a 50\% chi-square distribution with two degrees of freedom to predict the failure rate of a component that has not experienced any failures (IAEA, 1992; Tobias and Trindade, 1995), we find an average failure rate of $1.39 /(2 * 50$ years $)=$ $0.01 /$ year. The repair time would be on the order of the same time to repair the leaking weld on the vacuum vessel, 32 weeks, or 1.9E-04/hour. 
Vacuum vessel hatches or access port covers. There are more than 25 of these ports used in ITER; 20 on the midplane, and more on the lower part of the vacuum vessel (FDR, 1997). These hatches must form a vacuum seal, and they can be susceptible to the same sort of failures that the vessel walls are, cracks that cause leaks, large cracks that cause loss of structural integrity, and with these hatches, there is the question of seal leakage (since they are not welded, leakage is more probable). Failure rates for hatches are not known at this time. For present analyses, we shall assume that the set of hatches has an "all failure modes" failure rate of 1E-02/year, the high value in the unlikely events range and with an error factor of 10 . This assumption was made based on containment building penetration and access failure rates being in the $1 \mathrm{E}-06$ to 1E-07/hour range (Cadwallader and Piet, 1989). This assumption will be revisited as the design project continues to advance.

Repair times for these hatches are not known at this time. When more design details become known, then more accurate repair time estimates can be made. For the present time, we shall assume that the repair time for these hatches is on the order of 8 weeks (since an in-vessel module can be replaced in that time frame, then it should be possible to replace a hatch seal in the same time frame or less), or a repair rate of 7.4E04/hour.

Vacuum vessel piping penetrations. These penetrations are metal bellows penetrations. The bellows allow flexibility in the thermal expansion process for heat-up, bakeout, and shut down of the vessel cooling systems. Cadwallader (1994a) reviewed bellows failure rates for leakage and failure. Making the assumption that thin walled components like bellows will experience leaks as a majority of their failures, then geometrically averaging the all-modes values from Cadwallader (1994a) gives 5E-06/hour per bellows unit, with an assumed broad error factor of 10 . For large leakage, geometrically averaging the reported values gives $6 \mathrm{E}-07 /$ hour per bellows unit, with an error factor of 4 . Since the bellows are double walled for ITER (FDR, 1997), these average failure rates can be reduced by a factor of 10 for actual leakage to the surrounding environment. The factor of ten is adopted for the bellows walls based on the discussion of double walled piping in Marshall and Cadwallader (1994). Therefore, the ITER bellows failure rates are 5E$07 /$ hour for small external leakage (error factor of 10 ) and 6E-08/hour for large external leakage (error factor of 10).

Repair rates for bellows are not immediately known. For large flexible joints on oil wells, the active repair time was given at 100 hours for breaks, and 22 hours for large leaks (OREDA, 1992, page 575). As discussed in an engineering design file on maintenance (Cadwallader, 1996), the OREDA data has been chosen as the most reasonable and complete data set to use for supporting repair time estimates. Changing the vacuum bellows should be easier than fluid system bellows. This idea is based on the fact that fluid systems must be isolated, then the liquid drained out of the affected section. After the repair is completed, there can be additional time used to remove any air pockets 
trapped in the fluid system. In the vacuum system, nitrogen or another gas can be introduced into the chamber to equalize pressures at $0.1 \mathrm{MPa}$, thus preventing air admission. At the end of the repair, the vacuum pumps will simply remove the nitrogen just as they are designed to do. However, the bellows replacement may be done via remote handling and in confined spaces, so there could be time increases for these reasons. For the present time, since maintenance repair times vary, we shall be conservative and choose the value from the most coherent set of data, given in the OREDA report. Therefore, for leakage, the average active repair time is 22 hours $(\approx 1$ day), and for breaches the active repair time is 100 hours. Using one day gives a repair rate of 0.04 /hour, and for large leakage (breaches) the repair rate is $0.01 /$ hour. The cryostat vacuum should not have to be broken or the cryostat warmed to perform bellows replacement or repair (GDRD, 1995).

Vacuum vessel electrical penetrations. These penetrations will likely use ceramic materials such as alumina as the electrical insulator material. Preliminary reliability investigations on alumina insulators shows that alumina can be a strong material, but ceramics are more brittle than steels or other ductile metals. Cadwallader (1994a) gives electrical power feedthroughs a failure rate of 5E-04/year, with an upper bound failure rate of 5E-02/year. These values come from electrical distribution system insulators, and they compare well to informal results found at the Fermi National Accelerator Laboratory (FNAL). Herring (1995) gives information on FNAL reliability values. For instrumentation feedthroughs, a value determined from FNAL is used: 4E-03/year for a throughput leakage rate of $1 \mathrm{E}-06 \mathrm{~Pa}-\mathrm{m}^{3} / \mathrm{sec}$ or larger. The upper bound failure rate is taken to be $1 \mathrm{E}-02 /$ year, which is an error factor of 2.5 .

Repair rates for these feedthroughs are not known. At present, an assumption will be that for leaks, the penetration must be changed out, and this will be a time on the order for that of the bellows, or 100 hours (repair rate of $0.01 /$ hour). This value is only an engineering assumption - that the same level of difficulty is experienced in replacing a bellows as replacing a feedthrough. Modular design will greatly aid in performing remote replacement.

Optical penetrations. Vacuum windows could be used for laser diagnostics and perhaps other uses in the experiment. The glass may be quartz or perhaps some other silica material. A failure rate estimate from the existing fusion experiments gives a cracking (small leakage) failure rate of 1E-02/year for small and medium sized windows (Cadwallader, 1994b). The error factor for the window failure rate is 2 . This failure rate will be used until more data can be obtained. The throughput leak rate is assumed to be less than $1 \mathrm{E}-05 \mathrm{~Pa}-\mathrm{m}^{3} / \mathrm{s}$.

The repair time for these windows is not known. It is assumed to be on the order of the 100 hours (repair rate of 0.01 /hour) used for bellows and feedthroughs, so the repair rate is tentatively assumed to be $0.01 /$ hour. 
Rough vacuum pumps. These pumps might be roots blowers or other pumps designed to pump from atmospheric pressure down to a pressure range of about $50 \mathrm{~Pa}$. An important feature for ITER is that the pumps must handle steam and possibly handle overpressures of gases (helium or nitrogen) up to $0.5 \mathrm{MPa}$. The pumps are also listed as RH class 2 components (GDRD, 1995). From Cadwallader (1994b), the failure rates for rough vacuum pumps are $1.5 \mathrm{E}-05$ /hour with an error factor of 1.2 , and for external leakage, a failure rate of $5 \mathrm{E}-03 /$ year with an error factor of 10 .

Repair rates for these pumps are not known. There will be sufficient redundancy in the pump set to not require maintenance intervention following an individual component being declared out of service (GDRD, 1995). Replacement of one roughing pump should take less time than the 2 weeks needed for a primary pump replacement, so using two weeks as the upper bound is conservative in this case. Spampinato et al. (1984) estimated two days to replace a vacuum pump for the International Torus (INTOR) design. Since the GDRD is project documentation, we shall use the two weeks of repair time as the estimate for the present time, therefore 0.003 /hour is the upper bound repair rate.

Turbopumps. The turbopumps for a fusion reactor would be large units, perhaps over 9,000 1/s capacity. Such pumps would likely use ceramic bearings to preclude any problems with magnetic field saturation. For large turbopumps, a failure to operate rate is 9E-06/hour, with a error factor of 3, and an external leakage failure rate is $5 \mathrm{E}-03 /$ year, with an error factor of 10 (Cadwallader, 1994b).

The repair rate for these pumps is not known. The GDRD (1995) states that a primary torus pump must be replaced in less than two weeks during a scheduled maintenance session. There is sufficient redundancy to allow an individual pump to be shut down without disturbing the operations schedule. The $0.003 /$ hour value will be used as an upper bound repair rate on these pumps.

Cryopumps. Large cryogenic pumps using liquid helium should have a failure rate of 2E06/hour for failure to operate, with an error factor of 10 . Leaking cryogen into the vacuum chamber will have a failure rate of $2 \mathrm{E}-05 /$ hour, with an error factor of 1.7 , and a casing leak will have a failure rate of 5E-03/year, with an error factor of 10 (Cadwallader 1994b).

The repair rate for these pumps is not known. The GDRD (1995) states that a primary torus pump must be replaced in less than two weeks during a scheduled maintenance session. There is sufficient redundancy to allow an individual pump to be shut down without disturbing the operations schedule. Spampinato (1984) estimated that a pump replacement would take 2 days for the INTOR experiment, which was a smaller 
experiment than ITER but still similar in design. For the present time, we shall use the 0.003/hour upper bound repair rate for these pumps as discussed above.

Vacuum screens and filters. These devices are used to keep foreign objects (usually solids) out of the vacuum pumps. Some examples of foreign objects could be tokamakium dusts, re-frozen droplets of beryllium metal melted by a plasma disruption, very small pieces of metal from probe tips or antennas, various detritus left inside the vacuum vessel by oversight, etc. There is not much data available for metal screens and charcoal filters, so another approximation will be performed by using the most similar equipment data obtainable. OREDA (1992, page 513) gives an internal leakage failure rate for air filters as 2E-06/hour with an error factor of 4.7, a plugging failure rate of 9.9E-06/hour with an error factor of 2 , and a filter rupture failure rate of $2 \mathrm{E}-06 /$ hour with an error factor of 4.7. Repair times are 11 hours for plugged and leaking filters (with an upper bound of 23 hours), and 14 hours for ruptured filters (using the same upper bound). The repair rates are 0.09/hour for plugging and leakage, and 0.07/hour for ruptured filters. These hands-on repair times may be very liberal (i.e., very short times) to apply to ITER, considering the position of vacuum pump filters. However, little is known at present regarding plans to use remote equipment for filter changeout, frequency of routine filter changeout, etc.

Vacuum valves. These valves are large gate valves with electropneumatic operators (Özdemir and Perinic, 1994). Failure to change position on demand is 1E-04, with an error factor of 2. Spurious change of position is 3E-06/hour, with an error factor of 10 . External leakage is given a failure rate of $2 \mathrm{E}-07 /$ hour with an error factor of 10 , and internal leakage across the valve seat is given a general failure rate is $3 \mathrm{E}-06 /$ hour with an error factor of 30 (Cadwallader, 1994b).

The ITER vacuum vessel design description (FDR, 1997) mentions flap valves ahead of the cryopumps. Not much information is known about these valves, except they are not intended to positively seal, the flaps simply act to greatly decrease the gas flow into the cryopumps. For the present time, until more is known about these valves, the gate valve values given above can apply to these valves (except that there is no internal leakage failure rate for flap valves since they can flow past the valve flaps [closure members] even when the flaps are closed).

OREDA (1992, page 143) gives gate valve repair times of 4 hours and upper bound times of 8 hours. These times are highly optimistic for valves within the cryostat. Cadwallader (1996) gives suggested multipliers for estimating remote repair times from hands-on repair times, in this case for valves. Using a multiplier of 5 to signify an experienced operator gives a valve repair time of 20 hours with an upper bound of 40 hours, or a repair rate of $0.05 /$ hour with an upper bound of $0.025 /$ hour. 
Vacuum vessel pressure suppression tanks. These tanks are connected by $1 \mathrm{~m}^{2}$ ducts to the vacuum vessel (VV). Pairs of rupture disks isolate each tank from the VV during normal operations. The tanks remain at one atmosphere pressure and $20^{\circ} \mathrm{C}$ temperature. The tanks are designed to accept any steam overpressure from the vessel, up to $0.5 \mathrm{MPa}$, and condense the steam to reduce pressure in the system. These tanks require a failure on demand probability, as do the rupture disks. Reviewing failure rate data on tanks gives yearly failure rates for tanks between 1E-03/year to 1E-06/year (see Arulanantham and Lees, 1981; Davenport, 1991). Using the more recent and comprehensive work by Davenport, a leakage failure rate is on the order of $1.5 \mathrm{E}-05 /$ year and a rupture failure rate is on the order of $2 \mathrm{E}-06 /$ year.

The tank failure modes of interest would be leakage and rupture. Plugging is not considered in such large diameter piping or vessels. The published hourly values for failure rates will be converted to tank unavailability by using the formula (failure rate)(time interval between tests or inspections)/2. (see PRA PG, 1983) A test or inspection interval will have to be assumed, since this has not been set for ITER. Other tanks that perform a similar safety function could be inspected on a frequent basis (once a year or once each 18 months). We shall assume that the suppression tanks are visually inspected and pressure tested each 18 months. This value can be amended as more design and inspection details are made. At (1.5E-05/year)(1.5 year)/2, the unavailability of the suppression tank if it were called upon is $1.1 \mathrm{E}-05 /$ demand (the tank rupture value will be lower; the calculated value will be used as the upper bound in these calculations until actual inspection frequencies are known).

The rupture disks that separate the tank from the VV have an assumed failure rate of $1 \mathrm{E}-04$ per demand to rupture as discussed in Chapter 2. The rupture disks also have a leakage failure rate of $2 \mathrm{E}-06 /$ hour, with an assumed error factor of 5 . An interesting fact to note for operational safety is that rupture disk manufacturers recommend changing the disks out (replacing them on a regular basis) to avoid any concerns with corrosion (BS\&B, 1994; Nazario, 1988). Nazario (1988) states that there is no exact guidance on the frequency of replacement because individual conditions vary greatly, but most vendors suggest rupture disk replacement at least annually. Designers should consider what replacement frequency is appropriate for the suppression tank rupture disks.

The OREDA (1992, page 33) report discusses tank repairs. For significant external leakage, 26 hours repair time was cited, and for corrosion/erosion, 225 hours (maximum time, 496 hours or about 500 hours) were cited. Given the accessibility problems ITER has for piping outside of the primary heat transport system (PHTS) vault rooms, the longest maintenance time will be used here. The repair rate is $1 / 225$, or 0.004 /hour. The bounding repair rate is $0.002 /$ hour. Rupture disk replacement times were not treated in OREDA, nor in other suggested publications for repair times. An engineering assumption will be made that the disks are hands-on maintenance, and can be changed out in 2 hours (with a maximum of 8 hours). 
Vacuum ducts. Data on vacuum ducts comes from piping data. Some values were given in Cadwallader (1994b). Leakage was given a failure rate of 1E-08/hour-meter for all duct diameters and an error factor of 30 . The rupture failure mode was assumed to have a failure rate a factor of 100 lower than leakage.

Repair times for the RH class 3 vacuum vessel ducts have not been identified. Piping repairs are not discussed in OREDA (1992), but small tank repairs are discussed. Assuming these are similar types of repairs, then times would be similar. Small tank critical failure repairs can take on the order of 80 hours (OREDA, 1992, page 41). While this is a reasonable value for accessible tanks, it may be a very optimistic value for repair of vacuum ducts inside the ITER cryostat. If the cryostat must be warmed and then recooled, the task will take 4 weeks for warmup and another 4 weeks for cooldown (GDRD, 1995), or a total of over 8 weeks. Therefore, an upper bound estimate of the repair rate would be $1 /(8$ weeks* $168 \mathrm{~h} /$ week $)=7.4 \mathrm{E}-04 /$ hour.

Vacuum gauges. The failure rate for a Bayard-Alpert hot ion gauge or a Penning cold cathode ion gauge failing to operate is $6 \mathrm{E}-03 /$ year (error factor of 2.2), and the same value applies to the leakage failure mode (Cadwallader, 1994b). Rough vacuum gauges have failure rates for failing to operate of $1 \mathrm{E}-04 /$ hour with an error factor of 10 , and a leakage failure rate of $1 \mathrm{E}-03 /$ year with an error factor of 3 . It is likely that there are enough redundant gauges that one faulted gauge of any type does not require replacement until the next scheduled maintenance outage, so the repair time is not an important feature. Nonetheless, the time to replace a gauge should be less than 8 hours of remote handling time. This estimate is based on the idea that many maintenance tasks on small components can be completed in less than one operating shift (Cadwallader, 1996). An 8 hour repair time gives a repair rate of 0.125 /hour. 


\section{Chapter 3 References}

Arulanantham and Lees, 1981. D. C. Arulanantham and F. P. Lees, "Some Data on the Reliability of Pressure Equipment in the Chemical Plant Environment," International Journal of Pressure Vessels and Piping, $\underline{9}, 1981$, pages 327-338.

BS\&B, 1994.

BS\&B Special Applications and Preventive Maintenance, Catalog 77-1007, Section B: BS\&B Safety Heads and Rupture Disks, November 1994.

Buende et al., 1991.

R. Buende, S. Fabritsiev, and V. Rybin, "Reliability of Welds and Brazed Joints in Blankets and Its Influence on Availability," Fusion Engineering and Design, 16, 1991, pages 59-72.

Cadwallader and Piet, 1989. $\quad$ L .C. Cadwallader and S. J. Piet, 1989 Failure Rate Screening Data for Fusion Reliability and Risk Analysis, EGG-FSP-8709, September 1989.

Cadwallader, 1994.

L. C. Cadwallader, "Vacuum Vessel Reliability Issues," ITER/US/94/TE/SA-26, December 23, 1994.

Cadwallader, 1994a.

L. C. Cadwallader, "Vacuum Vessel Failure Modes and Effects Analysis and Suggested Penetration Failure Rates for the International Thermonuclear Experimental Reactor," ITER/US/94/TE/SA-23, December 12, 1994.

Cadwallader, $1994 b$.

L. C. Cadwallader, Vacuum System Operating Experience Review for Fusion Applications, EGG-FSP11037, March 1994.

Cadwallader, 1996.

L. C. Cadwallader, Determining Representative Handson Maintenance Times for ITER, ITER/US/96/TE/SA01, February 23, 1996.

Carter, 1986.

A. D. S. Carter, Mechanical Reliability, second edition, New York: John Wiley \& Sons, 1986, ISBN 0-47020694-2, pages 177-178.

Davenport, 1991.

T. J. Davenport, "A Further Survey of Pressure Vessel Failures in the UK," Reliability '91, Papers Presented at the International Conference on Reliability Techniques and Their Applications, June 10-12, 1991, London, England, pages 84-99.

FDR, 1997.

Technical Basis for the ITER Final Design Report, Cost Review and Safety Analysis (FDR), ITER Joint Central Team, draft published December 1997, Chapter II, section 4.1. Note, FDR to be published by the International Atomic Energy Agency. 
Fullwood, 1989.

GDRD, 1995.

Herring, 1995.

IAEA, 1992.
R. R. Fullwood, Review of Pipe-Break Probability Assessment Methods and Data for Applicability to the Advanced Neutron Source Project for Oak Ridge National Laboratory, BNL-52187, Brookhaven National Laboratory, April 1989.

Gamble and Strosnider, 1981. R. M. Gamble and J. R. Strosnider, Jr., An Assessment of the Failure Rate for the Beltline Region of PWR Pressure Vessels During Normal Operation and Certain Thermal Conditions, NUREG-0778, US Nuclear Regulatory Commission, June 1981, page 5-33.

General Design Requirements for the International Thermonuclear Experimental Reactor, presented as Chapter 2 of the Interim Design Report, June 12, 1995.

J. S. Herring et al., Final Report on the ITER Magnet Safety Design Task for 1994 and 1995, ITER/95/US/TE/SA-31, October 2, 1995.

Manual on Reliability Data Collection for Research Reactor PSAs, IAEA TECDOC-636, International Atomic Energy Agency, Vienna, Austria, January 1992, page 32 .

Marshall and Cadwallader, 1994. T. D. Marshall and L. C. Cadwallader, In-Vessel ITER Tubing Failure Rates for Selected Materials and Coolants, EGG-FSP-10928, EG\&G Idaho, Inc., March 1994.

Nazario, $1988 . \quad$ F. N. Nazario, "Rupture Discs, A Primer," Chemical Engineering, 95, June 1988, pages 86-96.

OREDA, 1992.

Offshore Reliability Data 1992 (OREDA 92), second edition, Hovik, Norway: DNV Technica, ISBN 82-5150188-1, 1992.

Özdemir and Perinic, 1994. I. Özdemir and D. Perinic, "Testing of Elastomersealed, Dust-contaminated Vacuum Valves," Vacuum, $\underline{45}$, pages 551-553, 1994.

PRA PG, 1983.

PRA Procedures Guide, NUREG/CR-2300, US Nuclear Regulatory Commission, January 1983, page 5-5.

Spampinato, 1984.

P. T. Spampinato et al., INTOR Critical Issue D: Maintainability, CONF 8410187-1, Oak Ridge National Laboratory, 1984.

Staat, 1993.

M. Staat, "Failure probabilities of the primary circuit pressure boundary of an HTR-Module for process heat generation under accident conditions for different failure modes," Nuclear Engineering and Design, 144, 1993, pages 53-67. 
Thomas, 1981.

Tobias and Trindade, $1995 . \quad$ P. A. Tobias and D. C. Trindade, Applied Reliability, second edition, New York: Van Nostrand Reinhold, ISBN 0-442-00469-9, 1995, pages 47-54, 70-71. 


\section{HEAT TRANSFER SYSTEM COMPONENT FAILURE AND REPAIR RATES}

Primary heat transfer systems (PHTSs) route cooling water to and from the ITER vacuum vessel and the in-vessel components (first wall/blanket, divertor, and vacuum vessel). There will be several sets of coolant piping to service the vacuum vessel and the in-vessel components. The failure rate values given here are generic in nature; they can be applied to any of the PHTS piping systems, or to other water cooling systems in other designs that call for similar equipment. The GDRD (1995) states that ceramic breaks are not needed in ITER coolant piping, so this component will not be treated here. The FDR (1997) states that to insure high reliability, the ITER designers will use proven technology, design standards, and experience of operation and maintenance developed in nuclear power plant design in the PHTS design. Therefore, nuclear fission plant data should be acceptable to use on the PHTS, at least for scoping purposes. Appendix A contains tables of these data values.

Ex-vessel coolant piping. This piping will be stainless steel, or perhaps carbon steel clad with stainless steel. The diameters of the pipe vary with the component being serviced and the required coolant flow. There are two failure modes of interest, leakage and rupture for these pipes. Plugging is not considered except for small diameter piping (that is, piping less than $203 \mathrm{~mm}$ diameter), and when plugging is considered the failure rate values for plugging are equal to those for rupture. Using fission reactor experience, a rupture/plugging piping failure rate for pipes larger than $76 \mathrm{~mm}$ diameter is $1 \mathrm{E}-10 /$ hoursection, where a section can vary from 4 up to perhaps 30 meters. Using 4 meters as an average section length (the length between discontinuities such as valves, joints, flanges, cross-tees, etc.) the average failure rate is $2.5 \mathrm{E}-11$ /hour-meter. The upper bound failure rate is $7.5 \mathrm{E}-10 /$ hour-meter. Small piping (diameters between $25.4 \mathrm{~mm}$ and $152.4 \mathrm{~mm}$ ) ruptures have a failure rate of 7E-11/hour-meter (IAEA, 1988). Past work by Cadwallader used generic factors to apply fission reactor experience to expected fusion experience (see Cadwallader, 1992). In this case, the many start-stop cycles of the heat transport system were expected to have small effects on reliability and were given a multiplier of 3 to account for these effects. Further investigation reveals that the piping will not suffer these effects to the extent that pump motors and frequently cycling valves will, so the multiplier will not be applied to coolant piping. For small piping $(25 \mathrm{~mm}$ to $76 \mathrm{~mm}$ diameter) a rupture failure rate of $7 \mathrm{E}-11$ /hour-meter is suggested with an error factor of 2, and for large piping (over $76 \mathrm{~mm}$ diameter), a rupture failure rate of $2.5 \mathrm{E}$ 11 /hour-meter is suggested with an error factor of 30 . There can be deleterious effects with the guard piping (Ziu, 1995), which will be addressed later in this chapter. The pipe rupture failure rates can be used as cited above. Leakage failure rates are larger than rupture values. Pipe leakage values are defined in the nuclear fission industry as usually being less than or equal to 50 gallons/minute (190 liters/minute) (Eide et al., 1993), and large leak/rupture flow rates are larger than that amount. 
Usually, a factor of ten difference between leakage and rupture failure rates is seen for piping (WASH-1400, 1975; Thomas, 1981; Adams and Sattison, 1990; Marshall and Cadwallader, 1994), while Fullwood (1989) and Eide et al. (1993) suggest that the difference could be larger, perhaps a factor of 25 or 100 . For the present time, the often used factor of ten will be applied for ITER piping, so the leakage failure rate for piping under $76 \mathrm{~mm}$ diameter is $7 \mathrm{E}-10 /$ hour-meter, and for piping over $76 \mathrm{~mm}$ diameter, the suggested leakage failure rate is $2.5 \mathrm{E}-10$ /hour-meter.

Repair for leaking pipes can be accomplished, but there are several issues to consider in piping repair. Accessibility (i.e., Obstructed by guard pipe?, Leak location is inside cryostat?), radiological exposure from radiolytic product decay and activated crud decay, piping isolation for welding, and other factors. The OREDA (1992, page 33) report does not address piping repairs, but it does discuss tank repairs. For significant external leakage, 26 hours repair time was cited, and for corrosion/erosion, 225 hours (maximum time, 496 hours, or about 500 hours) were cited. Given the accessibility problems ITER has for piping outside of the PHTS vault rooms, the longest maintenance time will be used here. The repair rate is $1 / 225$, or 0.004 /hour. The bounding repair rate is 0.002 /hour.

Guard pipes. These pipes are a second, larger diameter pipe that contains the coolant water pipe, usually a cluster of several cooling water pipes that are held in position relative to each other with spacers. The guard pipes run from the outer surface of the cryostat to the wall of the PHTS vault rooms. The guard pipes are exposed to most of the same failure mechanisms that the coolant pipes are - vibration, irradiation, and thermal cycling. However, they should experience less erosion, corrosion, and plugging, since they are not routinely handling hot water. Ziu (1995) discusses several failure mechanisms for containment piping: corrosion, mechanical stress from improper bracing of the hot inner pipe, weld flaw, impact or excessive mechanical load on both pipes, or other possible failure mechanisms. At this stage in the ITER design, the use of guard pipes is assigned a factor of 10 credit in reducing the failure rate of external leakage. That is, the guard pipe functioning reduces the admission of water into the cryostat or torus hall by $90 \%$ from the coolant line leakage values cited above (see Marshall and Cadwallader, 1994). For guard pipe rupture, the same factor of 10 difference between piping leakage and rupture is used. In calculations, this will be a 0.1/demand leakage failure rate for the guard pipe, and a $0.01 /$ demand rupture failure rate. This engineering assumption may be overly conservative, but Ziu (1995) points out numerous ways that a double failure can and has occurred, often from stresses induced by differential thermal expansion of a hot inner pipe and a cool outer pipe. The repair rate for the outer containment pipe should be short, unless the section of pipe is inside the cryostat. For the present time, we shall apply the maintenance repair times given above for coolant piping. Therefore, the repair rate for the guard pipes is 0.004 /hour, with a bound of $0.002 /$ hour. 
Centrifugal pumps. This type of pump is the most likely choice for ITER coolant systems. The centrifugal pump has good performance characteristics, moderate costs to operate, is reliable, and is a well-known pump to operate and service. Centrifugal pumps can easily accept a pony motor (that is, small electric motors that serve as auxiliary motors to turn the pump if the main motor is failed or depowered) as a safety provision for decay heat removal. The pony motor idea is receiving consideration from the ITER designers as a provision for decay heat removal.

Pumps can have several failure modes. Failure to start, failure to run, casing leakage, casing rupture, shaft leakage, overspeed, and reduced output. Cadwallader (1992) recommended using a factor of 3 increase from fission experience to apply failure rates to pulsed fusion equipment. This factor accounts for the wear of starts and stops, possible corrosion while in periodic downtime (wet lay up, etc.), and any other degradations the equipment might experience due to its on-off duty cycle. However, since ITER equipment will operate continuously, either bypassing the heat exchangers during outages or in a normal heat transfer alignment during pulse operations, fission pump failure rates will be used for ITER pumps. The IAEA (1988, page 162) gives large vertical centrifugal pump (up to 1900 liters/second flow rates) failure rates of $1.4 \mathrm{E}$ $05 /$ hour (error factor of 1.3) for reduced output operation and a repair time of 12 hours, 4E-06/hour for failure to run (error factor 1.5) with a repair time of 15 hours, and an external leakage failure rate of 3.6E-05 per hour (error factor of 1.2) with a repair time of 5 hours. Pump casing leakage and rupture are given by Eide et al. (1993) as 3E-08/hour (with an error factor of 10) and 3E-10 per hour (error factor of 30) for high quality pumps, respectively. Repair time for the significant external leakage mode is taken from the OREDA (1992, page 185) report, 41.6 hours for repair, with a bounding time of 146 hours. The OREDA (1992) report also gives 2.5E-02/demand for failure to start, with a repair time of 12 hours (repair rate is $1 / 12=0.083$ /hour) and an upper bound repair time of 150 hours. Pump overspeed appears to be included in failure to run, since overspeed will cause a pump to trip off-line. Pump shaft seal leakage can be a special case, since this has been a safety concern for US light water reactors (Ruger and Higgins, 1993). Since there are three shaft seals, with the second one designed to function at full system pressure if the first seal fails, the failure rate for independent failure of these seals is very low. Common cause failures have been examined for these seals, since a loss of the seal water can lead to leakage of large proportions, from $6 \mathrm{~m}^{3} /$ hour up to $110 \mathrm{~m}^{3} /$ hour. The seals could be lost if component cooling water to the seals is lost (Cheng, 1989), which is given a bounding frequency of $1 \mathrm{E}-04 /$ year. For the present time, we shall assume that the support system failure rate at $1 \mathrm{E}-04$ /year is a higher rate than the independent loss of the two diverse shaft seals. This can be an important failure event, since there is no way to isolate the leak and only system depressurization can slow the leak and system draining is the only way to stop the leak.

Pony motors. A pony motor is a second electric motor to turn the primary pump shaft at a slow rate [perhaps $10 \%$ of normal rpm's] for decay heat removal. The failure rate for a 
pony motor is assumed to be that for a large (many $\mathrm{kW}$ or MW scale) electric motor. The IAEA (1988, page 152) gives an "all modes" failure rate for a shutdown cooling pump motor as 1.6E-05/hour (with an error factor of 1.8) and a repair time of 184 hours. We shall assume that the all modes is largely failure to run. Eide and Calley (1993) give an electric motor failure to start as 3E-05/demand with an error factor of 10 . Repair times from OREDA (1992, page 185) are taken to be 12 hours average ( 0.083 /hour repair rate) and an upper bound of 150 hours, the same as for the pump main motor. Another failure for pony motor functionality would be pump shaft breakage. Pump shaft breakage should be on the order of 1E-08/hour (Carter, 1986, page 177) with a modest error factor [assume 10]. Shaft repair would be a major dismantlement operation for the pump, perhaps on the order of two weeks - one week to disassemble and one week to reassemble. This time would be a repair rate of 0.003 /hour.

Heat exchangers. Several heat exchanger failure modes have been noted in operations. These are tube leakage to the shell, external leakage of the shell, degraded heat transfer due to fouling or scaling, and flow blockage of the tubes (Schwartz, 1981). Eide et al. (1993) give values for heat exchanger tube leakage as 1E-07/unit-hour (with an error factor of 10), and tube rupture of 1E-09/unit-hour for high quality units (with an error factor of 30). Shell leakage is cited as $1 \mathrm{E}-08$ /hour (with an error factor of 10), and shell rupture is given as $1 \mathrm{E}-10 /$ hour for high quality units (with an error factor of 30). Tube fouling/plugging is assumed to be the same value as the tube rupture failure rate (see WASH-1400, 1975 and others). These values are for heat exchangers, not steam generators. There is no phase change of water in these units, simply heat transfer within the liquid phase. OREDA (1992, page 263) gives a failure rate of 2E-06/hour (error factor of 2) for erratic operation, taken to mean degraded heat transfer operation.

OREDA (1992, page 263) values for heat exchanger failure rates are somewhat more conservative than those cited above by factors of 5 or more. Repair times for heat exchangers are given as roughly 40 hours to repair tube leakage (maximum time is 160 hours), to repair significant internal leakage is 180 hours with an upper bound of 810 hours, external leakage has a repair time of 14 hours with an upper bound of 40 hours, and significant external leakage has a repair time of 34 hours with an upper bound of 90 hours. Fouled/plugged tubes are assumed to have repair times similar to leakage repair times. Heat exchanger cleaning to solve degraded operation can involve flushing operations which might take an entire shift of 8 hours (repair rate of $0.125 /$ hour) to complete.

Due to the safety concern about heat exchanger leakage leading to off-site releases, more discussion about heat exchanger construction and operating experiences is given later in this chapter.

Isolation valves. These valves, presumably gate valves or globe valves, serve to isolate parts of the flow system to allow repairs, or to prevent excessive flow if there is an 
accident situation. These valves will likely be motor operated valves that are situated well away from any fringe magnetic field so there is no induced electrical current in the motor windings. Failure modes of interest are failure to change position on demand, spurious closure, fail to remain closed after successful closure, external leakage through the stem or the body, external rupture of the valve body, and internal leakage across the valve seat. Fission plant operating experiences will be used directly to give values for valve failure rates since ITER cooling systems will operate nearly continuously, similar to power plants. Several data sources must be consulted for these failure and repair rates. IAEA (1988, page 268) gives 7.2E-03 per demand for isolation valves failing to change position, with an error factor of 5.3 and a repair time of 5 hours (0.2/hour repair rate). Eide and Calley (1993) give 5E-08/hour with an error factor of 10 for valve spurious operation (this incorporates spurious closure and failure to remain closed after successful closure), and 1E-07/hour for internal valve disk rupture (with an error factor of 10). Eide et al. (1993) give valve external leakage as 1E-08 per hour (error factor of 10) and valve body rupture of 1E-10/hour (error factor of 30) for high quality valves. Valve internal leakage has a failure rate of approximately 1E-06/hour with an error factor of 10 .

Repair times were taken from OREDA (1992, page 145). Spurious operation has a repair time of 9.3 hours and an upper bound of 32 hours (0.11/hour and 0.03/hour). Internal disk rupture was taken to be significant internal leakage, with repair times of 26.5 hours average and 35 hours maximum (0.038/hour and 0.029/hour). External leakage had a repair time of 18.7 hours with an upper value of 28 hours (0.053/hour and 0.036 /hour). Valve external rupture was interpreted to mean valve overhaul to repair the crack, so repair times were 52 hours as an upper bound (0.019/hour). Valve internal leakage was given repair times of 22.5 hours on average and 24 hours as an upper bound ( 0.044 /hour and 0.042 /hour).

Pressurizer. The pressurizer functions to moderate pressure changes in the coolant. It is a tank whose top half is filled with steam and whose lower half is filled with coolant. The tank is connected to the flow loop via a short length of pipe. Fission plant failure rates should apply directly to these components. Failure rates for tanks are taken from Eide et al. (1993) as 1E-08/hour (with an error factor of 10) for leakage, and 1E-10/hour (with an error factor of 30) for ruptures. Depending on the design, flow blockage is possible in the inlet to these tanks. For flow blockage, the rupture failure rate will be used as has been assumed in other data work (see WASH-1400, 1975 and others). The pressurizer also has a valve at the top to release steam if the pressure increases, and it has electric heaters in the bottom to produce more steam if the coolant pressure drops too much. IAEA (1988, pages 271-273) give several values for power operated relief valves failing to open and close. The order of magnitude from these entries is 4E-03/demand for failure to open and up to $1 \mathrm{E}-02 /$ demand for failure to close (even including flow of steam/water mixtures). These values have error factors of about 3. Repair times should be on the same time scale as safety valve repairs, OREDA (1992, page 89) gives 20 hours repair time (repair rate of 0.05 /hour) with an upper bound time of 245 hours. The pressurizer relief valve should 
also have an isolation valve. A so-called block valve allows easier repairs because it can isolate the system, it can also be used to isolate the relief valve if the relief malfunctions. IAEA (1988, page 273) gives a failure rate for the block valve failing to change position of $3.6 \mathrm{E}-02 /$ demand (with an error factor of 2.4). Other block valve failure modes and rates can be borrowed from the isolation valve discussion above. The repair time for this valve would be large, since the system would have to be shut down and cooled to allow any work inside the valve. The repair rate $(0.05 /$ hour $)$ for the relief valve will be used for this valve as well. IAEA (1988, page 140) gives a pressurizer electric heater failure rate of 2.2E-06/hour for failure to heat. An error factor of 10 is assumed for this value. Repair times are assumed to be on the order of time it takes to repair the pressurizer valve, or $0.05 /$ hour.

Flow instruments. Several instruments will be necessary to control the flow systems. Temperature, pressure, velocity flow, and level instruments will be needed. Basic failure and repair rates will be given here, but details about the control system, instrument redundancy, and other factors are not known at this stage of the ITER design. The fission plant failure rate data should apply directly to ITER components in this case. IAEA (1988, page 201) gave temperature sensors a failure to function on demand failure rate of 1.9E-03 per demand, with an error factor of 5.8 and a repair time of 3 hours $(0.33 /$ hour repair rate). For spurious operation, the temperature sensors had a failure rate of $7 \mathrm{E}$ 07/hour with an error factor of 2.6 and a repair time of 3 hours (0.33/hour repair rate). Pressure sensors in the IAEA (1988, page 199) report had failure rates of 7E-04/demand to operate, with an error factor of 3 and a repair time of 2 hours (repair rate of $0.5 /$ hour). The pressure sensors also had a spurious operation failure rate of $8.7 \mathrm{E}-07 /$ hour, with an error factor of 2.5 and a repair time of 2 hours (repair rate of $0.5 /$ hour). The IAEA report (1988, pages 197-198) had flow sensors: failure to function was given a failure rate of 3.3 demand with an error factor of 2.3 and a repair time of 2 hours. Spurious operation of flow sensors was given a failure rate of 4.3E-06/hour with an error factor of 5.3 and a repair time of 2 hours (repair rate of 0.5/hour). Level sensors (IAEA, 1988, pages 198199) had failure to operate on demand rates of 2.1E-04/demand with an error factor of 3 and a repair time of 3 hours. These units had a spurious operation failure rate of $8.2 \mathrm{E}-$ 07/hour with an error factor of 5.6 and a repair time of 3 hours.

Additional research has shown that most instrument types are matured technology, and a generic failure rate of 1E-06/hour for failure to operate (with an error factor of 3) is reasonable (Cadwallader, 1996a) until more is known about the sensor type.

Common cause failure rates. Guidance from the ITER Joint Central Team (SAG, 1995) has set representative common cause beta factors for active and passive equipment. The beta factor is a multiplier on the single component failure rate to describe the new rate for failing multiple components of the same kind. The beta factor for passive equipment is 0.01 , and for active equipment the beta factor is 0.10. The IAEA (1988a) has defined active equipment as needing power (electricity, instrument air, hydraulic pressure, etc.) or 
control signals to function; passive components do not. Passive components generally do not have any moving parts. Active components might be pumps, valves, circuit breakers, instruments, etc.; while passive components are cables, pipes, tanks, heat exchangers, confinement walls, etc. These suggested beta factors are slightly conservative but reasonable compared to other operating experiences; other authors recommend 0.1 as an average beta factor for active equipment (Moss and Sheppard, 1989; Fleming et al., 1985). When specific failure modes only challenge passive parts of a component, then the passive beta factor is assigned, such as for valve body ruptures.

Heat exchanger operating experiences and leak rates. Heat exchanger operating experience is important since this is a path where routine leakage can result in off-site releases of radioactive material. Heat exchanger failure modes and leakage performance are examined here. Information about existing water-to-water heat exchangers is presented, since these data are more similar to ITER uses than are steam generator data. Heat exchangers are passive equipment items, as described above, they must only contain the process fluids and provide transfer of heat through their walls. Although they are passive equipment items, heat exchangers can experience several failure modes. These failure modes and those heat exchanger performance issues that affect operational reliability are discussed below.

Potential Heat Exchanger Failure Modes and Design Challenges. According to Kutz and Palen (1986), heat exchangers can suffer from several common operational problems:

"When heat exchangers fail to operate properly in practice, the entire process is often affected, and sometimes must be shut down. Usually, the losses incurred by an unplanned shutdown are many times more costly than the heat exchanger at fault. Poor heat exchanger performance is usually due to factors having nothing to do with the heattransfer coefficient. More often the designer has overlooked the seriousness of some peripheral condition not even addressed in most texts on heat-exchanger design."

Kutz and Palen (1986) continue to discuss obvious heat exchange problems, which include: fouling, vibration, flow maldistribution, and temperature pinch. Fouling is perhaps the single worst heat exchanger problem. When solid material covers the heat exchange surfaces, heat transfer is reduced. The solid materials can come from precipitation of dissolved substances, deposit of particulate matter from the heat exchange fluids, chemical reactions, corrosion reactions, attachment and growth of biological organisms, and solidification by freezing. Often, extra tubes are specified to incorporate additional heat transfer surface area to account for decreased heat transfer from mild fouling. The hardness of water is the chief source of scale (fouling) in heat exchangers; hardness mainly comes from the presence of calcium and magnesium salts containing $\mathrm{Ca}^{2+}$ and $\mathrm{Mg}^{2+}$ (El Wakil, 1984). Other ionic compounds also contribute to scaling and fouling. The water must be treated to remove biological organisms, usually by 
chlorination, and then the water is softened to remove the calcium and magnesium. Usually, a demineralization process of ion exchange is used to remove these minerals. For ultra-pure water, the water flow enters a condensate polisher, which acts to filter the water and remove ions. As water flows through piping and tubing, it can entrain metallic ions, such as iron and copper. The polisher is a combination cation and anion exchanger, and filter.

Vibration of the heat exchanger tube bundles and baffles is also a problem (Kutz and Palen, 1986). With large units and high water flow velocities, tube failure by flowinduced vibration can be a problem. Generally, vibration problems occur when the distance between the baffles or tube support plates is too great. Flow velocities on the order of 2 to $3 \mathrm{~m} / \mathrm{s}$ in the tubes will usually preclude vibrations and also produce very little flow-induced erosion of the tube walls. Higher flow velocities will produce both vibration and erosion; both of these effects will damage tube walls and cause leaks between the tube and shell fluids.

Flow maldistribution can occur even in well-designed heat exchangers (Kutz and Palen, 1986). Up to $40 \%$ of the flow in the shell can divert from intended paths by leaking past tubes and baffles, and past the baffles and the shell. Forcing the shell flow into the tube bundle is needed to provide heat transfer, so design solutions of choice are increasing the tube pitch, using sealing strips on the baffles, optimizing baffle shape, and increasing the baffle spacing to ensure shell flow exchanges heat with the tube bundle.

Flow maldistribution can also occur in tubeside flows. If the water boxes do not distribute flow well, the highest velocity water could proceed through the tubes in the center of the tube bundle instead of evenly throughout tube bundle. Impingement plates can be used in the water boxes to appropriately distribute flow.

Temperature pinch is a condition where the hot and cold fluids entering the heat exchanger approach the same temperature (Kutz and Palen, 1986). Heat transfer stops as the temperatures of the two fluids equalize. Excessive flow maldistribution can lead to temperature pinch in heat exchangers with a low logarithmic-mean temperature difference. Designers can avoid temperature pinch by making sure shell flow thoroughly mixes within the tube bundle and does not bypass the tube bundle by leaking through the tubing holes in the baffle plates or between the baffle plates and the shell wall. Keeping temperatures of the inlet fluids near the design point is also important to ensure that heat transfer is accomplished.

Another problem area for heat exchangers is corrosion. If foreign materials build up and tube corrosion occurs, then leaks from tiny corrosion 'pin holes' through the tube walls will commence. Judging from sizes shown in photographs of damaged tubes provided in Herro and Port (1993), a large pin hole perforation in a tube wall could be approximately $0.3 \mathrm{~mm}$ in diameter. Of course, pin hole diameters can vary greatly; once 
a through-wall hole is formed it can continue to grow until it is repaired or the tube is replaced.

Compared to pin holes, flow-induced erosion in some feedwater heaters for fossil fueled power plants have created holes in tubes up to $3.2 \mathrm{~mm}(0.125 \mathrm{inch})$ in diameter (Stiebler, 1985). Fortunately, this high level of erosion should not occur in liquid-liquid heat exchangers because of their lower fluid velocities, but this typical experience with feedwater heaters does indicate an upper bound on the type of tube damage that could be seen in the all-liquid heat exchangers. Steam generator tubes at $13 \mathrm{MPa}$ and $340 \mathrm{C}$ have had leaks from cracks and holes created by wear. These leaks have been tabulated (Adams and Sattison, 1990), they show an average leak rate of $0.14 \mathrm{~kg} / \mathrm{s}$. The largest reported steam generator leakage flow rate under typical pressurized water reactor (PWR) conditions was $1.9 \mathrm{~kg} / \mathrm{s}$ and the smallest flow rate was $0.006 \mathrm{~kg} / \mathrm{s}$. Tube ruptures were significantly higher flow rates, 7 to $48 \mathrm{~kg} / \mathrm{s}$. The smaller leakage flow rates are similar to those cited later in this report for liquid-liquid heat exchangers. Other steam generator experiences at Electricite de France (Flesch and Keroulas, 1989) showed a PWR steam generator tube leak of $\approx 3 \mathrm{E}-06 \mathrm{~kg} / \mathrm{s}(0.01$ liter/hour $)$. The plant readjusted its permissible leakage value of 72 liters/hour down to 5 liters/hour to be able to monitor the leaking tube more closely since there was a concern that the leaking tube might rupture. The plant staff wanted to quickly mitigate any tube rupture if the tubing crack propagated, so they increased surveillance of the leaking and they reduced the acceptable leakage rate accordingly.

The Heat Exchanger Design Handbook (HEDH, 1989) also discusses several ways that the heat exchanger tubes might experience failures. Flow-induced vibration from high velocity shell-side flows can cause tubes to "jump rope", that is, to flex in a sinusoidal manner between their supports. These flexing tubes can start touching or impacting each other, eventually wearing holes through the tube walls. The flexing can also cause wear at the tube support locations (usually the flow baffles); this wear can eventually lead to holes and leakage. Holes can have different areas, from very tiny, like pin holes, up to perhaps one $\mathrm{cm}^{2}$ or larger. Since there is such wide variability in the breach area, often these are bounded by assuming a tube rupture in safety analysis work.

Another failure mode discussed in the HEDH (1989) is tube weakening their tubeto-tubesheet joints due to thermal expansion, especially when the tube bundles experience differential cooling if they are removed for cleaning too quickly. The tube bundles can also experience mechanical stresses from steady and transient flows, and temperature variations of the tube and shell fluids can also cause tubing deterioration. Double tubesheets are noted to create stresses due to the two tubesheets being at different temperatures, creating lateral forces on the tubes (Yokell, 1979).

The HEDH (1989) also discusses corrosion. Corrosion can also cause tube wear and lead to pin hole leakage. Corrosion can also cause scale buildup on the tubes so that 
heat transfer is degraded. The HEDH (1989) directs designers to account for some amount of scale buildup when calculating the overall heat transfer coefficient for the heat exchanger; effectively adding extra tubes to increase the surface area to ensure adequate heat transfer. This is a conservatism in the design if the amount of scaling or fouling is overestimated. Other authors, Smallwood (1977) and ASM (1975), also discuss tubing corrosion and other failure modes such as material defects in the tubes.

Another aspect of failure modes for heat exchangers is failure due to intermittent operations. Yokell (1987) discusses how intermittent operation allows noncondensible gases, mainly air, to accumulate in a heat exchanger. The presence of air can help to produce corrosive agents in the heat exchanger, so corrosion occurs. When used intermittently, the heat exchanger must be stored correctly (i.e., 'wet lay up') to reduce corrosion and build up of excessively thick oxide layers on both the tube interior and exterior surfaces.

Most of these failure modes have been seen in typical power plant heat exchangers (Moyers, 1992; Schwartz, 1981; Yokell and Andreone, 1995). For non-power cycle heat exchangers (these are usually water-to-water heat exchangers), out of 712 recorded events, internal leaks were $39 \%$ of the failures, external leaks were $30 \%$, tube blockage was $22 \%$, impaired heat transfer was $4 \%$, impending external leakage was $3 \%$, impending internal leakage was $1 \%$, and about $1 \%$ of the failures were shell blockage and other causes. Internal and external leakage are problems to be taken seriously for all shell-and-tube heat exchangers.

While proper use of shell and tube heat exchangers is sometimes difficult, shelland-tube heat exchangers are the most often used heat exchange units in the US: they are rugged, offer a high surface area for heat transfer, have plentiful design information to guide designers, these units can deal with phase change and aggressive temperature/pressure conditions, and they offer positive separation between the two fluid streams (HEDH, 1989). Plate heat exchangers are an option for liquid-liquid heat exchange at modest temperatures and pressures. Plate heat exchangers suffer from different failure modes than shell-and-tube units (Kerner et al., 1987), but they can give acceptable lifetimes (Hager, 1991).

Heat Exchanger Design Specifications. Heat exchanger specification sheets do not suggest an acceptable leak rate between the high pressure and low pressure fluids. Apparently this lack of leakage specification is because when the heat exchanger is built, it is built with the intent that there should be zero leakage. The ASME Boiler and Pressure Vessel Code for unfired vessels (ASME, 1995) also does not give a design specification for an acceptable tube-to-shell leakage rate for liquid-liquid heat exchangers. Perhaps the acceptable leakage rate is more a matter of tolerability in an individual situation than of industry-wide prescriptive specification. For example, water leakage into hydraulic fluid would have a lower acceptable leak rate than process cooling 
water leaking into service water or boiler feedwater leaking into steam in a closed feedwater heater. Radioactive water leakage probably has the lowest acceptable rates of all. Very small leaks would be quite difficult to determine and to locate in the tube bundle, even when using acoustic sensors. Large leaks (tubes splitting or rupturing) would be easier to determine because of the more obvious fluid pressure changes, and a quick shut down for repair would be needed.

The Tubular Exchanger Manufacturers Association (TEMA, 1988) does not give an acceptable leak rate either, probably for the same reasons discussed above. The operation and maintenance guidance does discuss locating and repairing tube leaks, but not acceptable leak rates. This is also true for the standards of the Heat Exchange Institute (HEI, 1980).

Fraas and Ozisik (1965) state that a leak test leakage rate for a heat exchanger with a high degree of tightness would be perhaps as little as $1 \mathrm{~cm}^{3} /$ day. This is indeed a very small leakage to expect under normal operations, but is probably representative of a very leak-tight heat exchanger unit. The Savannah River heat exchangers have a leakage acceptance criteria of $1 \mathrm{E}-04$ standard $\mathrm{cm}^{3} / \mathrm{second}$ (Morrison et al., 1992) or $\approx 1 \mathrm{E}-07 \mathrm{~kg} / \mathrm{s}$. This leak rate converts to $8.6 \mathrm{~cm}^{3} /$ day for comparison to the Fraas and Ozisik value.

Heat Exchanger Leak Detection. Tiny amounts of leakage from the tubes to the shell (or vice versa, depending on the pressure gradient) of a heat exchanger are difficult to detect unless there is some notable feature about the leak. For example, leaking cooling water into lubricating oil for a diesel generator will be noted since the oil becomes chemically contaminated over time, or leaking tritiated water into fresh water will be noted in tiny quantities since the tritium is radioactive. Another way to detect leakage is if the leak causes a process upset or an off-normal condition. Woodruff and Lammers (1977) discuss detecting leaking tubes in power plant feedwater heaters: tube leakage may be detected by an excessive amount of water being discharged from the feedwater heater shell. A large leak may overload the feedwater heater drainage system, causing the heater to become flooded. The feedwater heater will not raise the feedwater temperature adequately in this situation, yielding a system off-normal condition. Another means to detect a large leak is by the heat exchanger pressure fluctuations. If the tubes carry a high pressure, and leak into the shell then the shell will begin to pressurize. Guidelines (HEI, 1980) direct designers to size relief valves on the heat exchanger shell so that they have the capacity to vent overpressure from a tube rupture event.

Liquid-liquid Heat Exchanger Operating Experiences. There is a wealth of literature about steam generator issues and problems, but there is not much literature about the operating experiences of liquid-to-liquid heat exchangers. Qualitatively, leaks are mentioned along with methods to alleviate the leaks (for example, see Lord et al., 1979). Fortunately, the operating experiences with heat exchangers at the Savannah River K Reactor plant are generally applicable to ITER, since the K Reactor also does not 
produce steam (this reactor rejects heat to river water or to a cooling pond). Parameters of the K Reactor heat exchangers are given in Table 2. The Savannah River C, K, L, P, and $\mathrm{R}$ reactor heat exchangers have experienced small leaks from the tubeside reactor $\mathrm{D}_{2} \mathrm{O}$ coolant into the shellside river water. These small leaks would probably not be detectable except that they leaked tritium with the $\mathrm{D}_{2} 0$, and the small amount of tritium was measurable in the previously uncontaminated shellside river water. For example, the estimated leak rate in one event from 1991 was $0.003 \mathrm{~kg} / \mathrm{s}$ ( 0.046 gallons $/$ minute) or about $250 \mathrm{~kg} / \mathrm{day}$. Table 3 summarizes the leaks experienced in the dozen heat exchangers for the C, L, K, P and R reactors over their operating times (a combined total of over 110 reactor-years). Each of those Savannah River reactors has 12 heat exchanger units, all similar to that described in Table 2. The ITER heat exchanger parameters (SADL, 1996) for the first wall generally are more robust than those of the Savannah River heat exchanger - ITER equipment has almost twice the flow rate (but still below the typical 2 to $3 \mathrm{~m} / \mathrm{s}$ level of concern for flow-induced erosion and vibration), more than double the operating temperatures, about half the number of tubes but ITER tubes are larger diameter, and somewhat higher heat transfer per heat exchange unit. These heat exchangers are still similar in size and construction materials, and neither has any thermodynamic phase change that leads to chemical buildup and corrosion. Values for Savannah River units are generally applicable to ITER units because of their similarities. Savannah River heat exchanger tubing may even give slightly pessimistic results since there is a high number of tubes per heat exchange unit; there are more tube-to-tubesheet welds and more tubes that could suffer damage in one Savannah River heat exchanger than in one ITER heat exchanger.

Heat Exchanger Care and Maintenance. Heat exchangers are usually built to allow disassembly for cleaning the tube surfaces. The tube bundle of u-tube units can be removed to allow thorough cleaning of the tube outer surfaces. When examining heat exchangers for leaks, it is important to note that in horizontally mounted u-tube units, the water will drain down to about $25 \%$ of the tube inner diameter (Linley, 1985). This residual water in the tubes can present a hazard to any personnel who enter the heater channel for tube inspections. The water should be blown out of the tubes with compressed air or nitrogen. The best approach for personnel safety is to only enter the heat exchanger when it is out of service and it has cooled down all the way to room temperature. Fortunately, ITER should have the time available to perform sensible maintenance instead of hurrying to bring a system back on-line.

Finding leaks in heat exchangers can be done in many different ways (Reason, 1985). Some of these methods work better than others for given applications. Generally, the methods that encompass sets of tubes simultaneously are better than those that require individual tube inspection. One promising means of leak detection is the piezoelectric pressure transducer. When placed in the feedwater, the sound transmitted from the leaking tube is registered. The sensitivity of such a system can be up to $0.16 \mathrm{~kg} / \mathrm{s}(2.6$ 
Table 2. Savannah River K Reactor heat exchanger parameters.

12 shell-and-tube heat exchanger units for the $\mathrm{K}$ reactor, 2 units in parallel for each of 6 reactor coolant loops

K Reactor thermal power level has varied between 200 to 2915 MW for nuclear materials production

Heat exchanger shell is made of carbon steel, about $32 \mathrm{~mm}$ thick

Tubes are made of 304 Stainless Steel, straight tube design. $\mathrm{D}_{2} \mathrm{O}$ in tubes, river water in the shell.

Tubes are $12.7 \mathrm{~mm}$ (0.5 inch) in outer diameter, and $1.24 \mathrm{~mm}$ thick (18 BWG, Birmingham Wire Gage)

Double tubesheets at both ends to negate $\mathrm{D}_{2} \mathrm{O}$ to river water leakage at the tubesheet joints; inner tubesheet is $28.5 \mathrm{~mm}$ thick, outer tubesheet is $38.1 \mathrm{~mm}$ thick, $50 \mathrm{~mm}$ between sheets

Total tubing surface area for heat transfer $3060 \mathrm{~m}^{2}\left(33,000 \mathrm{ft}^{2}\right)$ per unit, and there are 8,957 tubes per unit

Heat exchanger units are $10.2 \mathrm{~m}$ (33.5 feet) long, and $2.3 \mathrm{~m}$ (7.5 feet) in diameter

Tube side $\mathrm{D}_{2} \mathrm{O}$ flow rate, maximum of $845 \mathrm{~kg} / \mathrm{s}$ (12,500 gallons/minute), roughly $1 \mathrm{~m} / \mathrm{s}$ tube side flow velocity

Tube side $\mathrm{D}_{2} \mathrm{O}$ inlet temperature, maximum of $90^{\circ} \mathrm{C}\left(194^{\circ} \mathrm{F}\right)$

Tube side pressure, maximum of approximately $1.3 \mathrm{MPa}$ (200 psig)

Shell side river water flow rate, approximately $950 \mathrm{~kg} / \mathrm{s}$ (15,000 gallons/minute), roughly $0.3 \mathrm{~m} / \mathrm{s}$ shell side flow velocity

Shell side river water inlet temperature, approximately $15^{\circ} \mathrm{C}\left(59^{\circ} \mathrm{F}\right)$ on average

Shell side river water inlet pressure not given, probably under $0.75 \mathrm{MPa}$ (100 psig)

These parameters come from Bebbington (1990), Tinnes et al. (1990), McKane et al. (1960), and Britt (1987), or they were calculated based on these data. 
gallons/minute), which is stated to be much better than other methods such as hydrazine trace level monitoring (Reason, 1985a).

Heat exchanger tubes can be repaired in many different ways (Smith and Sort, 1988). These tubes can be re-expanded or flared to re-seat against the tubesheet. They can be welded to re-make the seal to the tubesheet, although welding heat can lead to shortened tubesheet lifetime if not applied carefully. The tubes can be plugged in a variety of ways to isolate the particular tube from the tubeside flow; then the plug must maintain its seal so fluid from the shell does not leak into the tubeside fluid. Plugs have been welded, explosion expanded, and mechanically threaded. Shape memory alloys have also been used for plug materials. Plugs can be removable in case the plugging was preventive and some advanced method becomes available to repair the tube. The heat exchanger tubes can be removed, although this is dependent on the design of the heat exchanger. The tube sheet holes are plugged with thimbles and by mechanical plugs. If the tube pitch is too restrictive, then tube removal is difficult. Certainly, on u-tube units, only the outermost tube rows are removable (or replaceable). Tube sleeving is also performed on leaking tubes. Straight tubes can have a full length sleeve. Generally, utubes can only be sleeved for the straight runs to sleeve the areas where the tubes are supported (baffles and tubesheet); the u-bends cannot be sleeved. Gutzwiller and Glass (1988) discuss methods for $\mathrm{u}$-tube care, including eddy current inspections, preventive tube plugging, and heat treatment to improve tube life. Smith and Sort (1988) also discuss the effects of foreign objects in the shell; these objects can perforate tubes in a short time if left to carom off the walls and tubes of the tube bundle. Some objects (piece of wire, a stone, etc.) left in the Savannah River heat exchangers were listed in Table 3, and these did create small leaks from the tubes to the shell.

The amount of tubes that can be plugged will vary with the heat exchanger design. Various authors have stated what are tolerable amounts of tubes to be plugged shut. Linley (1985) suggests that plugging more than $10 \%$ of the tubes will begin to cause a loss of thermal performance. Rose and Andreone (1985) suggest that plugging 15 to $20 \%$ of the tubes indicates the end of useful life for a feedwater heater due to the increased tubeside pressure drop. The options at that point are to refurbish the existing tube bundle or to replace the tube bundle. If replacement is chosen, then the staff is free to select which tube material will be used. For example, at Savannah River, some replacement heat exchanger tube bundles used austenitic stainless steel 316L (unified numbering system S31603) in some units and sea-cure alloy, a ferritic stainless steel alloy (unified numbering system S44660) in the remainder of the units instead of simply replacing the 304 stainless steel tubes (Mertz et al., 1992) with like material. 
Table 3. Summary of leaks in Savannah River heat exchangers

\begin{tabular}{|c|c|c|}
\hline$\underline{\text { Cause of Leak event }}$ & $\underline{\text { Leak rate in } \mathrm{kg} / \mathrm{s}}$ & $\underline{\text { notes and comments }}$ \\
\hline Debris & $2.2 \mathrm{E}-03$ & $\begin{array}{l}\text { welding electrode left inside heat exchanger, } \\
\text { vibrated }\end{array}$ \\
\hline Debris & $2.2 \mathrm{E}-04$ & tie rod spacer vibration damage \\
\hline Debris & $1.39 \mathrm{E}-04$ & insulated wire found in heat exchanger \\
\hline Debris & $7.6 \mathrm{E}-04$ & small stone found in heat exchanger \\
\hline Debris & $\begin{array}{l}4.2 \mathrm{E}-04 \text { to } \\
2 \mathrm{E}-03\end{array}$ & $\begin{array}{l}\text { bristles from brushes used to clean tubes, } \\
\text { cleaning method was changed }\end{array}$ \\
\hline $\begin{array}{l}\text { Stress corrosion } \\
\text { cracking }\end{array}$ & $\begin{array}{l}2.5 \mathrm{E}-06 \text { to } \\
2 \mathrm{E}-05\end{array}$ & $\begin{array}{l}\text { chlorides inadvertently introduced, } \\
\text { these were chemically inhibited }\end{array}$ \\
\hline $\begin{array}{l}\text { vibration induced } \\
\text { failures }\end{array}$ & $7.6 \mathrm{E}-05$ to 0.2 tul & bration against tube baffles \\
\hline
\end{tabular}

The K Reactor has operations guidance to shut down for repairs or replacement if a heat exchanger tube-to-shell leakage rate is greater than $2.6 \mathrm{E}-06 \mathrm{~kg} / \mathrm{s}(1.1 \mathrm{~kg} /$ day or 0.5 pounds/day). (Morrison et al., 1992)

Data listed in columns above was taken from Cramer et al. (1992). There have been 63 leaks of heat exchangers over 35 years at Savannah River, and the probability of any leakage up to $2.5 \mathrm{E}-05 \mathrm{~kg} / \mathrm{s}(0.2$ pounds/hour $)$ is $0.22 /$ reactor-year; tube leaks of flow rates up to $2.5 \mathrm{E}-03 \mathrm{~kg} / \mathrm{s}$ (20 pounds/hour) have a probability of $0.013 /$ reactor-year, and tube leaks of $5 \mathrm{E}-03 \mathrm{~kg} / \mathrm{s}$ (40 pounds/hour) have a leakage probability of $0.004 /$ reactor-year (Cramer et al., 1992). 
Based on the experiences of the Savannah River reactors, a $1.1 \mathrm{~kg}$ /day leak rate per heat exchanger appears to be bounding for ITER heat exchangers. This finding should be compared to other water-to-water heat exchangers, such those used by Canadian Deuterium-Uranium (CANDU) reactors. CANDU reactors have accumulated much more than 110 reactor-years of experience. Fusion designs should take advantage of heat exchanger design practices from other industries to keep the flow rates low to avoid flow-induced erosion and flow-induced vibration. Both of these effects can be deleterious to tubes if flow velocities are too high. 


\section{Chapter 4 References}

Adams and Sattison, $1990 . \quad$ J. P. Adams and M. B. Sattison, "Frequency and Consequences Associated with a Steam Generator Tube Rupture Event," Nuclear Technology, 90, 1990, pages $168-185$.

Arulanantham and Lees, 1981. D. C. Arulanantham and F. P. Lees, "Some Data on the Reliability of Pressure Equipment in the Chemical Plant Environment," International Journal of Pressure Vessels and Piping, 9 , 1981, pages 327-338.

ASM, 1975.

American Society for Metals, Metals Handbook, eighth edition, volume 10, Failure Analysis and Prevention, Failures of Heat Exchangers, ASM, Metals Park, Ohio, 1975, pages 545-558.

ASME, 1995.

American Society of Mechanical Engineers, Boiler and Pressure Vessel Code, an Internationally Recognized Code, "Section VIII, Rules for Construction of Pressure Vessels, Division 1," ASME, New York, July 1, 1995.

Bebbington, 1990.

W. P. Bebbington, History of du Pont at the Savannah River Plant, published by the E. I. du Pont de Nemours and Company, Wilmington, DE, ISBN 0-934870-27-6, 1990, chapter 6.

Britt, 1987.

T. E. Britt, Safety Analysis of Savannah River Production Reactor Operation, DPSTSA-100-1, Du Pont de Nemours and Company, October 1987.

Cadwallader, $1992 . \quad$ L. C. Cadwallader, Investigation of Component Failure Rates for Pulsed versus Steady State Tokamak Operation, EGG-FSP-10262, July 1992.

Cadwallader, 1996a.

L. C. Cadwallader, Reliability Estimates for Selected Sensors in Fusion Applications, INEL-96/0295, September 1996.

Carter, 1986.

A. D. S. Carter, Mechanical Reliability, second edition, New York: John Wiley \& Sons, 1986, ISBN 0-47020694-2, pages 177-178.

Cheng, 1989.

S.-K. Cheng, "Seal Loss-of-Coolant Accident and Recovery Actions Following loss of Component Cooling Water," Nuclear Technology, $\underline{84}$, 1989, pages $305-314$. 
Cramer et al., 1992.

Eide and Calley, 1993.

Eide et al., 1993.

El-Wakil, 1984.

FDR, 1997.

Fleming et al., 1985.

Flesch and Keroulas, 1989.

Fraas and Ozisik, 1965.

Fullwood, 1989.

GDRD, 1995.
D. S. Cramer et al., Probability of Heat Exchanger Leaks, WSRC-TR-92-96, Westinghouse Savannah River Company, February 1992.

S. A. Eide and M. B. Calley, "Generic Component Failure Rate Database," Proceedings of the International Topical Meeting on Probabilistic Safety Assessment, PSA '93, American Nuclear Society, Clearwater Beach, FL, January 26-29, 1993, pages 1175-1182.

S. A. Eide et al., "Component External Leakage and Rupture Frequency Estimates," Proceedings of the International Topical Meeting on Probabilistic Safety Assessment, PSA '93, American Nuclear Society, Clearwater Beach, FL, January 26-29, 1993, pages 1171-1174.

M. M. El-Wakil, Powerplant technology, McGraw-Hill, New York, ISBN 0-07-019288-X, 1984, pages 251-254.

Technical Basis for the ITER Final Design Report, Cost Review and Safety Analysis (FDR), ITER Joint Central Team, draft published December 1997, Chapter II, section 4.6. Note, FDR to be published by the International Atomic Energy Agency.

K. N. Fleming et al., Classification and Analysis of Reactor Operating Experience Involving Dependent Events, EPRI-NP-3967, Electric Power Research Institute, June 1985.

B. Flesch and F. de Keroulas, "Steam Generator Tube Cracks at Dampierre 1 EdF PWR Plant Impact on Plant Safety," Nuclear Engineering and Design, 113, 1989, pages 357-368.

A. P. Fraas and M. N. Ozisik, Heat Exchanger Design, John Wiley \& Sons, New York, 1965, pages 266-267.

R. R. Fullwood, Review of Pipe-Break Probability Assessment Methods and Data for Applicability to the Advanced Neutron Source Project for Oak Ridge National Laboratory, BNL-52187, Brookhaven National Laboratory, April 1989.

General Design Requirements for the International Thermonuclear Experimental Reactor, presented as Chapter 2 of the Interim Design Report, June 12, 1995. 
Gutzwiller and Glass, 1988.

Hager, 1991.

HEDH, 1989.

HEI, 1980.

Herro and Port, 1993.

IAEA, 1988.

IAEA, 1988a.

Kerner et al., 1987.

Kutz and Palen, 1986.

Linley, 1985.
J. E. Gutzwiller and S. W. Glass, "New Options for Improved Steam Generator U-Bend Integrity," International Journal of Pressure Vessels and Piping, 34, 1988, pages 95-108.

M. J. Hager, "Selection, Operation and Maintenance Experience with Flat Plate Heat Exchangers," Practical Aspects and Performance of Heat Exchanger Components and Materials, PWR-Vol. 14, American Society of Mechanical Engineers, 1991, pages 41-45.

D. L. Aldred et al., contributors, Heat Exchanger Design Handbook, Hemisphere Publishing Corporation, New York, ISBN 0-89116-125-2, 1989.

Heat Exchange Institute, Inc., Standard for Power Plant Heat Exchangers, first edition, HEI, Cleveland, Ohio, 1980.

H. M. Herro and R. D. Port, The NALCO Guide to Cooling Water Failure Analysis, McGraw-Hill, Inc., New York, ISBN 0-07-028400-8, 1993, pages 319-320.

Component Reliability Data for Use in Probabilistic Safety Assessment, IAEA-TECDOC-478, International Atomic Energy Agency, Vienna, Austria, 1988, pages 157-158.

Code on the Safety of Nuclear Power Plants: Design, IAEA Safety Series No. 50-C-D (Rev. 1), IAEA, Vienna, Austria, 1988.

J. Kerner et al., "Where Plate Exchangers Offer Advantages Over Shell-and-Tube," Power, 131, May 1987, pages 53-58.

M. Kutz, editor, Mechanical Engineers' Handbook, and J. W. Palen, Chapter 67, Heat Exchangers, Vaporizers, Condensers, John Wiley \& Sons, New York, ISBN 0471-08817-X, 1986.

F. H. Linley, Jr., "The Impact of Tube Plugging on Closed Feedwater Heater Operation and Maintenance," in Piping, Feedwater Heater Operation, and Pumps, PVP 98-9, American Society of Mechanical Engineers, 1985, pages 177-184. 
Lord et al., 1979.

R. C. Lord, P. E. Minton, and R. P. Slusser, "Guide to Trouble-Free Heat Exchangers," in Process Heat Exchange, published by Chemical Engineering, New York, ISBN 0-07-010742-4, 1979, pages 60-67.

Marshall and Cadwallader, 1994. T. D. Marshall and L. C. Cadwallader, In-Vessel ITER Tubing Failure Rates for Selected Materials and Coolants, EGG-FSP-10928, EG\&G Idaho, Inc., March 1994.

McKane et al., 1960.

R. H. McKane et al., Stainless Steel Failures in Savannah River Plant Reactor Areas, DP-539, E. I. du Pont de Nemours \& Co., November 1960.

Mertz et al., 1992.

G. E. Mertz et al., Savannah River Reactor Process Water Heat Exchanger Tube Structural Integrity Margin Task Number 92-005-1, WSRC-TR-92-72, Westinghouse Savannah River Company, February 1992.

Morrison et al., 1992.

J. M. Morrison et al., Heat Exchanger Restart Evaluation, WSRC-TR-92-97, revision 1, Westinghouse Savannah River Company, March 18, 1992.

Moss and Sheppard, 1989. T. R. Moss and G. T. Sheppard, "Common-Cause Failures - Evidence from Sellafield," in V. Colombari (editor), Reliability Data Collection and Use in Risk and Availability Assessment, Proceedings of the 6th EuReData Conference, Siena, Italy, March 15-17, 1989, pages 141-154.

Moyers, 1992.

J. C. Moyers, Aging of Non-Power-Cycle Heat Exchangers Used in Nuclear Power Plants, NUREG/CR-5779, US Nuclear Regulatory Commission, July 1992.

OREDA, 1992.

Offshore Reliability Data 1992 (OREDA 92), second edition, Hovik, Norway: DNV Technica, ISBN 82-5150188-1, 1992.

Reason, 1985.

J. Reason, "Find Condenser Leaks Faster by Using the Right Technique," Power, 129, December 1988, pages 17-22.

Reason, 1985a.

J. Reason, "Microphones in the Boiler Give Early Warning of Tube Leaks," $\underline{\text { Power, }}$ 129, July 1988, pages 62-64. 
Rose and Andreone, 1985. $\quad$ D. M. Rose and C. F. Andreone, "Life Extension for Closed Feedwater Heaters," in Piping, Feedwater Heater Operation, and Pumps, PVP 98-9, American Society of Mechanical Engineers, 1985, pages 243-251.

Ruger and Higgins, $1993 . \quad$ C. J. Ruger and J. C. Higgins, "Reactor Coolant Pump Seal Issues and Their Applicability to New Reactor Designs," Proceedings of the Sixteenth Reactor Operations International Topical Meeting, Long Island, NY, August 15-18, 1993, American Nuclear Society, 1993, pages 148-153.

SADL, 1996.

H.-W. Bartels, editor, Safety Analysis Data List, version 1.1, S 81 RE 3 96-03-05 W1.1, ITER Joint Central Team, Safety, Environment and Health Division, San Diego Joint Work Site, March 15, 1996.

SAG, 1995.

A. E. Poucet et al., Safety Analysis Guidelines, version 1, ITER Joint Central Team, S 81 RI 1 95-12-13 F1, December 1995, page 15.

Schwartz, 1981.

M. P. Schwartz, "Four Types of Heat Exchanger Failures," Plant Engineering, 31, October 1981, pages 145-150.

Smallwood, 1977.

R. E. Smallwood, "Heat Exchanger Tubing Reliability," Materials Performance, 16, February 1977, pages 2734.

Smith and Sort, 1988.

K. Smith and M. Sort, "Steam Generator Repair," International Journal of Pressure Vessels and Piping, 34, 1988, pages 31-45.

Stiebler, 1985.

T. J. Stiebler, "Feedwater Heater Shell Side Leaks: Their Causes and Cures," in Piping, Feedwater Heater Operation, and Pumps, PVP 98-9, American Society of Mechanical Engineers, 1985, pages 197-204.

TEMA, 1988.

Standards of the Tubular Exchanger Manufacturers Association, seventh edition, TEMA, Inc., Tarrytown, New York, 1988.

Thomas, 1981.

H. M. Thomas, "Pipe and Vessel Failure Probability", Reliability Engineering, 2, 1981, pages 83-124. 
Tinnes et al., 1990.

WASH-1400, 1975.

Yokell, 1979.

Yokell, 1987.

Ziu, 1995.
S. P. Tinnes et al., "Results of the Level 1 Probabilistic Risk Assessment (PRA) of Internal Events for Heavy Water Production Reactors," Proceedings of the International Topical Meeting on the Safety, Status and Future of Non-Commercial Reactors and Irradiation Facilities, September 30-October 4, 1990, Boise, Idaho, American Nuclear Society, pages 247-251.

US Nuclear Regulatory Commission, Reactor Safety Study - An Assessment of Accident Risks in US Commercial Nuclear Power Plants, NUREG-75/014, WASH-1400, October 1975, Appendix III.

Woodruff and Lammers, 1977. E. B. Woodruff and H. B. Lammers, Steam-Plant Operation, McGraw-Hill Book Company, New York, ISBN 0-07-071731-1, 1977.

S. Yokell, "Double-Tubesheet Heat-Exchanger Design Stops Shell-Tube Leakage," in Process Heat Exchange, published by Chemical Engineering, New York, ISBN 0-07-010742-4, 1979, pages 56-59.

S. Yokell, "Extending the Life of Tubular Heat Exchangers," Chemical Engineering, 94, July 1987, pages $74-86$.

Yokell and Andreone, 1995. S. Yokell and C. F. Andreone, "What to Look for in

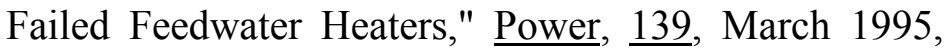
pages 74-76.

C. G. Ziu, Handbook of Double Containment Piping Systems, New York: McGraw-Hill, ISBN 0-07-073012$1,1995$. 


\section{SELECTED PERSONNEL SAFETY COMPONENT FAILURE RATES}

This chapter discusses some issues of component reliability that affect personnel safety, such as sensors for radiation, oxygen content in the atmosphere, and other equipment. Of course, process equipment failures can also lead to personnel hazards (e.g., steam leaks from valves, instruments leaking process fluids, etc.). The safety issues for chemical exposure are treated in Lipton and Lynch (1994). Potential exposure to radioactive material leaks would be analyzed on a case-by-case basis for the systems that contain tritium, fusion ash, or other radioactive materials.

There are a variety of sensors and instruments that are used to protect the plant staff. The categories of sensors discussed here are: radiation detectors, oxygen monitors, toxic and combustible gas sensors.

\subsection{Radiation Sensors}

There are a variety of radiation sensors for personnel protection. One of the most widespread methods of protection is to monitor the indoor atmospheric air to determine if there are airborne radioactive materials (aerosols, radioactive gases) in the breathing air. These monitors are called continuous air monitors, or cam's. The most basic monitor uses the gas ionization principle to detect radiation. Incoming ionizing radiation (alpha, beta, or gamma radiation) will cause ionization in the gas that is housed in the detector chamber (Tsoulfanidis, 1983). The ion pairs created in this gas will migrate to opposite sides of the detector chamber since a voltage potential is set up across the chamber. For that reason, the chamber is called an ionization chamber. The continuous air monitor requires a metered air pump for a constant volume of air inflow, the power supply for the ionization chamber, the electronics to register the chamber output current from the collected ions, setpoint comparison and alarm circuitry, and many chambers are also fitted with local alarms (i.e., an audible alarm such as a horn or bell, and a visual alarm such as a flashing light).

Depending on the facility, there can also be criticality monitors to detect neutrons from the criticality of fissile materials. These are not a concern for the majority of energy technology experiments, such as fusion technology. Nonetheless, Alber et al. (1995) give some data on criticality monitors.

Other radiation monitors detect radioactive contamination on surfaces, or on people's clothing. Usually hand-held meters (small counters using the gas ionization method) are used for surface surveys, or swipe samples on small cloths are taken by health physicists and measured in a scintillation counter. The small cloths (often plastic foam or light paper) are immersed in a liquid inside small vials. The liquid, called 'scintillation cocktail' and usually made of a benzene compound, will fluoresce when irradiated. The light given off is very small, and is amplified in a photomultiplier tube to 
be counted as a radioactive decay from material on the cloth. Scintillation counters are sensitive to low energy radiation, such as the low energy beta particle given off by tritium decay.

Personnel at nuclear facilities survey themselves for radioactive contamination by passing next to gas ionization counters called portal monitors or by standing in front of large area detectors. These names are given to the monitors since the first is shaped like a doorway or portal that a person walks through, and the second since the set of monitoring window openings to the gas chambers are large by detector standards (on the order of $0.1 \mathrm{~m}^{2}$ each). Personnel monitors for detecting contaminated clothing are usually gas ionization counters.

An important aspect of using radiation survey meters is the environment that they operate in. Liu et al. (1993) determined that magnetic fields of up to 10 milliTesla will not affect some meters, but these magnetic fields can cause some meters to read low by a factor of 10. This is an important effect to consider for magnetic fusion facilities and particle accelerator facilities.

Blanton and Eide (1993) give a radiation sensor failure rate for failure to operate as $5 \mathrm{E}-06 /$ hour, with an upper bound of $2.5 \mathrm{E}-05 /$ hour. The sensor is assumed to be a typical gas counter. Earlier work by Dexter and Perkins (1982) quoted a failure rate of 1.39E-05/hour for a gas counter, without giving an upper bound. Alber et al. (1995) gave a radiation meter drift failure rate of 2.3E-05/hour (with an upper bound of $1.2 \mathrm{E}-04 /$ hour) and a failure to operate failure rate of 3.4E-05/hour (with an upper bound of 7.4E-05/hour). A specialized tritium monitor was analyzed for its reliability by Cadwallader et al. (1991) and found to have failure rates of 2.2E-06/hour for high readings (a 95\% upper bound failure rate of $1 \mathrm{E}-05 /$ hour) and 2.2E-06/hour for reading low (a 95\% upper bound of 1E-05/hour). Each of the tritium monitors is out of service for recalibration about 672 hours each year.

These failure rates do not account for loss of electrical power to the radiation sensors. In general, it would appear that the proper order of magnitude for a radiation sensor failure rate is $1 \mathrm{E}-05 /$ hour for failure to operate.

\subsection{Oxygen sensors}

Gas analyzers are used to monitor gas concentrations in the atmosphere. Oxygen monitors are used in areas where there is the possibility of another gas displacing the normal air concentration of oxygen, for example in the ITER cryoplant and in rooms where cryodistribution piping is located. Oxygen can be sensed using an electrometric method (Norton, 1982). The sensing element is a zirconium-dioxide tube, shaped like a test tube. Electrodes are fixed to the inside and outside of the tube, and the tube is electrically heated. The atmospheric gas is flowed over the outside of the tube, and a 
specific concentration of oxygen is contained inside the tube. At high temperatures, over $400 \mathrm{C}$, the side of the tube having a higher oxygen concentration (higher oxygen partial pressure) will become the better electrolytic conductor (the anode) because of the higher number of oxygen ions present. A voltage will be produced according to the Nernst equation, voltage $=$ (constant)(temperature of the tube)(log [oxygen reference pressure/oxygen pressure in atmospheric gas]). The output voltage is converted to read as parts per million of oxygen in the atmospheric gas (Norton, 1982). Considine (1985) states that the response time is typically 3 seconds, and the output signal is in the milliVolt region.

Parry et al. (1993) and Herig (1989) also discuss the use of electrochemical cells for oxygen sensing. The electrochemical cell (a fuel cell) reacts oxygen with hydrogen to produce electricity and water. The amount of electricity produced is proportional to the oxygen concentration. Electrodes are coated with a catalyst (perhaps nickel, silver, or platinum) and immersed in an electrolyte (such as aqueous potassium hydroxide). Air flows over the catalyst, reacting oxygen with an inflow of hydrogen (fuel) gas, with reactions being induced by the catalyst. The cell runs at room temperatures as opposed to the heated methods described above (Considine, 1985). Another type of oxygen sensor that is used by industrial hygienists is the galvanic cell sensor (NSC, 1988; Considine, 1985). The oxygen makes this cell produce an electrical current in proportion to the partial pressure of oxygen present.

Oxygen sensor placement is important to give timely notification of a possible problem. For example, if dealing with liquid helium, any escape of this cryogen will result in a gas cloud at the ceiling; even though the helium is very cold its natural buoyancy still causes it to rise, pool at the ceiling, and then move horizontally down back into the room as it expands upon warming (Parry et al., 1993; Blyukher, 1995). Oxygen sensors $60 \mathrm{~m}$ apart on the ceiling could be adequate to protect occupants for helium releases in large rooms. Cryogenic nitrogen behaves the opposite from helium. Nitrogen is about the same molecular weight as air, so its cold temperature causes it to sink to the floor and then rise and mix with the atmospheric air as it warms. Four sensors near the floor, and four mid way up the room walls were used to protect one room housing a cryogenic system for possible nitrogen leaks (Blyukher, 1995), and the monitors were set to alarm at $19.5 \%$ by volume of oxygen (see NSC, 1992). Parry et al. (1993) discussed that the lifetime of the electrochemical cells in oxygen sensors is 9 to 24 months, and that the sensors are wired for two-out-of-three voting logic. A total of 21 sensors was used in a magnet testing lab. The setpoint value of $19.5 \%$ is also cited in the Code of Federal Regulations (29CFR1917.23) for oxygen deficient atmospheres. The normal volume concentration of oxygen in air at atmospheric pressure and sea level is approximately $20.95 \%$.

The obvious failure modes of these instruments are that they have a finite lifetime due to the electrolytic effect by which they sense oxygen, the sensing tube can become 
fouled with foreign material deposits to yield false readings, electrodes can fail (open circuit, short circuit), the resistance heater can fail (also by open circuit or short circuit), or the converter circuitry can fail. Another issue with these detectors is that they can only sample air in local areas, so if there is a release of an oxygen-displacing gas, it will take time to register with the sensor. Multiple sensors are important to reduce this time to notification. Miller and Mazur (1984) note that instrument drift with oxygen monitors can be over $1 \%$ oxygen concentration, so they choose to set the alarm level at $1 \%$ higher than the hazardous level. At FNAL, they cited $18 \%$ as the alarm level. Miller and Mazur (1984) also noted that personal oxygen monitors (chosen for their warning of oxygen deficiency in proximity to the worker, high reliability, and low cost) have failure probabilities less than 1E-04 [assume per demand to alert worker], but the worker errorof-omission rate in failing to don the monitor or turn the monitor on was 1E-02 per oxygen deficiency event. In their analysis, Miller and Mazur (1984) neglected the monitor failure rate in favor of the much larger human error rate of failure to use the personal monitor.

Anyakora et al. (1971) gave a value of 5.65/year for an overall oxygen analyzer failure rate. Using 8760 hours/year, this gives 6.5E-04/hour. This is a rather high value. As noted in past work, the early data from the 1970's often has higher values than later studies. This is perhaps due to improvements in electronics in the last 20 years. Blanton and Eide (1993) gave a failure to operate failure rate of 1E-05/hour with an upper bound of $1 \mathrm{E}-04 /$ hour. The type is not known, but the Blanton and Eide data are probably a newer type of sensor, perhaps the electrochemical cell that operates at modest temperatures. The Blanton and Eide data is suggested for use on oxygen sensors. The repair times are probably similar to the gas detectors discussed below.

\subsection{Toxic Gas Detectors}

These sensors can also operate in much the same way as the oxygen sensors (Norton, 1982). Herig (1989) describes many kinds of these sensors, both hand held and wall mounted units that use thermal catalyst methods, infrared scanning methods, and others. Thin metal film-oxide materials are used because their electrical resistance properties will change when gas molecules diffuse into them, such as the tin-oxide sensor for nitrogen oxides. A platinum-activated tungsten-oxide sensor measures hydrogen concentrations (Norton, 1982). Other materials are used as catalysts to sense sulfur oxides, hydrogen sulfide, and other contaminant gases. Scanning Herig (1989) shows that most units have response times in the seconds range, nearly all being under one minute. The detector catalyst may only last on the order of 6 months before requiring replacement. Calibration intervals vary from one month up to calibration only at the time of catalyst changeout. The possible failure modes for these sensors are the same as those for the oxygen monitors. 
Another means to detect toxic gases is to use the wheatstone bridge, with one of the wires covered in a catalyst that will speed up reactions of the gas with oxygen in air. Air contaminated with the gas to be analyzed is moved across the catalyst coated wire. Heat from the reaction will be noted in the resistance change of the wire in the wheatstone bridge. The resistance change is proportional to the concentration of gas in the air. This method is discussed below in the section on combustible gas detection.

There are other reasons to sample gases besides personnel protection. For example, one application for sensing toxic gases is to give an alert of combustion. Sensing carbon monoxide (White, 1993) can alert fossil fueled power plant operators of possible fires in the coal being processed for combustion in the boiler. Since carbon monoxide is an intermediate molecule formed in the combustion process, its presence signifies combustion occurring. These detectors compare the content of carbon monoxide in inlet and outlet air for coal pulverizers or other coal handling equipment. The early units experienced maintenance problems, such as clogged probes and filters (from coal dust) and filter degradation. Newer air collection probes are screened and filtered more highly to reduce plugging and abrasion from coal dust.

One of the leading data sources available is the Offshore Reliability Data Handbook (OREDA, 1992). This handbook documents data collected at offshore oil drilling platforms. The data are characterized, components are described and their boundaries defined, and the statistics are presented. The OREDA handbook gives values for gas detectors:

\begin{tabular}{|c|c|c|c|}
\hline$\underline{\text { sensor }}$ & failure mode & $\begin{array}{l}\text { average } \\
\text { failure rate }\end{array}$ & $\begin{array}{l}90 \% \text { upper bound } \\
\text { failure rate }\end{array}$ \\
\hline \multirow{3}{*}{$\begin{array}{l}\text { catalyst method } \\
\text { for hydrocarbon } \\
\text { gas detection }\end{array}$} & maximum or zero output & 1.7E-05/hour & $3.5 \mathrm{E}-05 /$ hour \\
\hline & no output & $8.5 \mathrm{E}-06 /$ hour & $1.5 \mathrm{E}-05 /$ hour \\
\hline & high output & 3.7E-05/hour & $5.5 \mathrm{E}-05 /$ hour \\
\hline \multirow{2}{*}{$\begin{array}{l}\text { hydrocarbon } \\
\text { detectors }\end{array}$} & low output & 3.3E-05/hour & 6.1E-05/hour \\
\hline & erratic output & 5.5E-07/hour & 8.4E-07/hour \\
\hline
\end{tabular}

The repair times for these units were an average of 9 hours, with a high time of 68 hours. The testing frequency was given as 1 to 3 month test and service intervals for cleaning and maintenance (OREDA, 1992). The detector head was usually changed to solve failure problems. The 1 to 3 month service interval agrees with the suggestion by Katzel (1996) of a routine monthly sensor check, to replenish any consumable materials and clean the sensor so it is free of obstructions. 
Another source of data for hydrocarbon gas sensors was found. Bodsberg (1994) gave a total failure rate for these catalytic units of 1.1E-05/hour, where $91 \%$ of the failure rate was non-critical failures, $4.5 \%$ (that is, $\sim 5 \mathrm{E}-07 /$ hour) were critical failures of failing to operate when needed, and the other $4.5 \%$ was spurious operation. The upper bound failure rate could vary by perhaps up to a factor of up to ten, but is more likely to be in the range of 3 because the data set is large.

Scanning these data, it appears that the order of magnitude for a generic failure rate to apply to gas detectors is $1 \mathrm{E}-05 /$ hour for the critical failures. The OREDA data could be used on other sensors if they are the catalyst type.

\subsection{Combustible Gas Sensors}

Sensors that detect combustible hydrocarbon gases typically use a heat of combustion approach. A sample of the atmosphere is drawn into a chamber where a catalyst resides. Catalyst materials are chosen based on the combustible gas to be measured. The catalyst reacts a small amount of the combustible gas that has been ingested with the inlet atmospheric air, and the temperature increase of the catalyst due to the combustion heat is measured against the inlet air temperature. Usually, a platinum wire resistance temperature detector is used for this temperature measurement (see Chapter 2). The temperature change is proportional to the concentration of the combustibles in the inlet gas stream. Many of these sensors are calibrated to report the percentage relative to the lower explosive limit or the lower flammability limit of the combustible gas to be measured (Norton, 1982; Herig, 1989). There is design guidance for combustible gas sensors (ISA, 1987). The failure modes for these sensors are the same as those for oxygen sensors.

Scanning the toxic gas sensor data, it appears that those generic failure rates will also apply to combustible gas sensors. The failure rate is 1E-05/hour for the critical failures. The OREDA (1992) data could be used on other sensors if they are the catalyst type.

In this chapter, safety sensors for personnel protection were discussed. The types discussed were radiation sensors, oxygen, toxic gas, and combustible gas sensors. Basic failure modes were listed and failure rate data from the literature was given. Repair times are more difficult to find in the literature, but some are cited.

Some other areas where reliability data support personnel safety analyses are plant system or equipment failures that create hazardous conditions in the ITER buildings (for example, see Cadwallader, 1995; and Cadwallader et al., 1998), and plant equipment failures that could directly lead to personnel injuries (an example of this kind of failure is a fault of material handling equipment, see Cadwallader, 1997). Other areas to pursue are 
the reliability of personal protective equipment, and the reliability of amelioration or safety equipment provided to mitigate worker injuries. 


\section{Chapter 5 References}

Alber et al., 1995.

Anyakora et al., 1971.

Blanton and Eide, 1995.

Blyukher, 1995.

Bodsberg, 1994.

Cadwallader et al., 1991.

Cadwallader, 1992.

Cadwallader, 1995.
T. G. Alber et al., Idaho Chemical Processing Plant Failure Rate Database, INEL-95/0422, Idaho National Engineering Laboratory, August 1995.

S. N. Anyakora et al., "Some Data on the Reliability of Instruments in the Chemical Plant Environment," The Chemical Engineer, No. 255, November 1971, pages 396-402.

C. H. Blanton and S. A. Eide, Savannah River Generic Database Development, WSRC-TR-93262, Westinghouse Savannah River Company, 1995.

B. Blyukher, "Oxygen Deficiency Hazard (ODH) Analysis for Pressure and Cryogenic Systems Facilities," Structural Integrity of Pressure Vessels, Piping, and Components - 1995, PVP-318, American Society of Mechanical Engineers, ISBN 0-7918-1349-5, 1995, pages 169-175.

L. Bodsberg, "Optimal Voting Logic of Hydrocarbon Gas Detectors Based on Field Data," presented at the Second International Conference on Probabilistic Safety Assessment and Management (PSAM II), San Diego, CA, March 20-25, 1994, paper 55-19.

L. C. Cadwallader, M. A. Stolpe-Gavett, and L. Quintana, Tritium Room Air Monitor Component Failure Data Analysis from January 1, 1984 to December 31, 1990, EGG-FSP-9450, EG\&G Idaho, Inc., May 1991.

L. C. Cadwallader, Cryogenic System Operating Experience Review for Fusion Applications, EGGFSP-10048, EG\&G Idaho, Inc., January 1992.

L. C. Cadwallader, Fire Protection System Operating Experience Review for Fusion Applications, INEL-95/0396, Idaho National Engineering Laboratory, December 1995. 
Cadwallader, 1997.

Cadwallader et al., 1998.

Considine, 1985.

Dexter and Perkins, 1982.

Herig, 1989.

ISA, 1987.

Katzel, 1996.

Lipton and Lynch, 1994.

Liu et al., 1993.
L. C. Cadwallader, Lift Truck Safety Review, INEL/EXT-97-00178, Idaho National Engineering and Environmental Laboratory, March 1997.

L. C. Cadwallader, C. S. Miller, and K. A. McCarthy, "Potential Vacuum Hazards and Proposed Solutions for Personnel Safety During an Air Ingress Accident in ITER," presented at the Thirteenth Topical Meeting on the Technology of Fusion Energy, Nashville, TN, June 7-11, 1998.

D. M. Considine, editor in chief, Process Instruments and Controls Handbook, third edition, McGraw-Hill Book Company, New York, ISBN 007-012436-1, 1985, chapter 6.

A. H. Dexter and W. C. Perkins, Component Failure-Rate Data with Potential Applicability to a Nuclear Fuel Reprocessing Plant, DP-1633, Savannah River Laboratory, July 1982.

S. V. Herig, editor, Air Sampling Instruments for Evaluation of Atmospheric Contaminants, seventh edition, American Conference of Governmental Industrial Hygienists, Cincinnati, OH, ISBN 0936712-82-1, 1989.

International Society for Measurement and Control (ISA), Installation, Operations and Maintenance of Combustible Gas Detection Instruments, RP 12.13 Part II-87, recommended practice, ISA, Research Triangle Park, North Carolina, 1987.

J. Katzel, "What you need to know about fixed gas detection systems," Plant Engineering, $\underline{50}$, July 1996, pages 54-58.

S. Lipton and J. Lynch, Handbook of Health Hazard Control for the Chemical Process Industry, John Wiley \& Sons, Inc., New York, 1994.

J. C. Liu et al., "The Effect of the Static Magnetic Field on the Response of Radiation Survey Instruments," Health Physics, 64, 1993, pages 5963. 
Miller and Mazur, 1984.

Norton, 1982.

NSC, 1988.

NSC, 1992.

OREDA, 1992.

Parry et al., 1993.

Tsoulfanidis, 1983.
T. M. Miller and P. O. Mazur, "Oxygen Deficiency Hazards Associated with Liquefied Gas Systems: Derivation of a Program of Controls," American Industrial Hygiene Association Journal, 45, 1984, pages 293-298.

H. N. Norton, Sensor and Analyzer Handbook, Prentice Hall publishers, Englewood Cliffs, NJ, ISBN 0-13-806760-0, 1982, chapter 8.

National Safety Council, Fundamentals of Industrial Hygiene, third edition, NSC, Itasca, IL, ISBN 087912-082-7, chapter 9.

National Safety Council, Accident Prevention Manual for Business and Industry, Engineering and Technology, tenth edition, NSC, Itasca, IL, ISBN 087912-156-4, page 489.

OREDA, Offshore Reliability Data Handbook, second edition, distributed by DNV Technica, Hovik, Norway, ISBN 82-515-0188-1, 1992, pages 420-430.

R. Parry et al., A High Reliability Oxygen Deficiency Monitoring System, SSCL-preprint 430, Superconducting Super Collider Laboratory, May 1993.

N. Tsoulfanidis, Measurement and Detection of Radiation, McGraw-Hill Book Company, New York, ISBN 0-07-065397-6, 1983, chapter 5. 


\section{CONCLUSIONS}

This report documents a wide variety of component failure rate and repair rate data for components that are used in magnetic fusion facilities. Tables of these data values are given in the text and in Appendix A. These generic, or scoping, data values add to the accumulation of data that can be used in system design studies, probabilistic safety analysis, and probabilistic risk assessment for both public safety evaluations and worker safety studies. Data such as these, with input from the equipment manufacturers and other concerns, can also support plant operations and maintenance.

These data can be submitted to the IEA task 7 on failure rate data, to further the collaboration between countries for the advancement of magnetic fusion energy. Some of these data can be useful to domestic studies of various magnetic fusion reactor designs. 
Appendix A - Data Tables 


\begin{abstract}
APPENDIX A - Data Tables
The component failure rate data values for vacuum components and heat transfer components discussed in the main body of this report are listed here in tabular form. An Excel spreadsheet can be used to arrange these data for input to a probabilistic risk assessment computer code or other automated application. Data values and selection rationale are explained in the main body of this report.
\end{abstract}


Table A-1. Vacuum System Data Table.

\begin{tabular}{|c|c|c|c|c|c|c|c|c|c|c|c|c|c|c|c|c|c|c|c|c|c|c|c|c|}
\hline \multicolumn{4}{|c|}{\begin{tabular}{|l|l|}
\multicolumn{2}{|c|}{ Component identification according INEL } \\
taxonomy
\end{tabular}} & \multirow{3}{*}{ Function } & \multirow{3}{*}{\begin{tabular}{|l} 
Component \\
boundaries \\
\end{tabular}} & \multirow{3}{*}{\begin{tabular}{|c|} 
Ooperting \\
regime \\
\end{tabular}} & \multirow{3}{*}{\begin{tabular}{|c} 
Maintenance \\
regime \\
\end{tabular}} & \multirow{2}{*}{\multicolumn{17}{|c|}{ Info Failure Rates }} \\
\hline \multirow{2}{*}{ System } & \multirow{2}{*}{ Subsytem } & \multirow{2}{*}{\multicolumn{2}{|c|}{\begin{tabular}{|l|l|} 
Component sub \\
Classititation \\
\end{tabular}}} & & & & & \multicolumn{2}{|c|}{ Failure mode } & \multirow{2}{*}{\begin{tabular}{|c} 
Average \\
value
\end{tabular}} & \multirow{2}{*}{\begin{tabular}{|l} 
Error \\
factor \\
\end{tabular}} & \multirow{2}{*}{\begin{tabular}{|c} 
Type of \\
disistributio \\
n
\end{tabular}} & \multirow{2}{*}{ Description } & & & & & & & & & & & \\
\hline & & Lev. 1 & & & & & & code. & Description & & & & & \begin{tabular}{|l} 
Average \\
value \\
\end{tabular} & \begin{tabular}{|l} 
Error \\
factor \\
\end{tabular} & \begin{tabular}{|c|} 
Type of \\
distribution \\
\end{tabular} & Description & $\begin{array}{c}\text { Average } \\
\text { value } \\
\end{array}$ & $\begin{array}{l}\text { Error } \\
\text { factor } \\
\end{array}$ & \begin{tabular}{|l}
$\begin{array}{r}\text { Type of } \\
\text { distributio } \\
\text { nit }\end{array}$ \\
\end{tabular} & Description & \begin{tabular}{|l} 
Average \\
value \\
\end{tabular} & \begin{tabular}{|l} 
Error \\
factor \\
\end{tabular} & \begin{tabular}{|l} 
Type of \\
disistibution
\end{tabular} \\
\hline $\begin{array}{l}\text { Vacuum } \\
\text { system }\end{array}$ & $\begin{array}{l}\text { Double } \\
\text { walled } \\
\text { vacuum } \\
\text { vessel }\end{array}$ & vessel walls & Lev. 2 & $\begin{array}{l}\text { vacuum } \\
\text { boundary }\end{array}$ & $\begin{array}{l}\text { outer surace } \\
\text { of vessel }\end{array}$ & continuous & RH class 3 & Coue & |leakage & $\begin{array}{l}1.5 E-05 \\
\text { per year }\end{array}$ & 1.2 & exponential & Descripion & $\begin{array}{l}1.9 E-04 \\
\text { per hour }\end{array}$ & & \begin{tabular}{|l} 
point \\
estimate
\end{tabular} & Descripuion & 0.01 & & $\begin{array}{l}\text { point } \\
\text { estimate }\end{array}$ & Descripion & & & \\
\hline $\begin{array}{l}\text { Vacuum } \\
\text { system }\end{array}$ & $\begin{array}{l}\text { 吕uble } \\
\text { walled } \\
\text { vacuum } \\
\text { vessel } \\
\text { vessel }\end{array}$ & vessel walls & & $\begin{array}{l}\text { vacuum } \\
\text { boundary }\end{array}$ & $\begin{array}{l}\text { outer surface } \\
\text { of vessel }\end{array}$ & continuous & RH class 3 & & rupture & 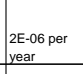 & 1.2 & exponential & ruppure & $\begin{array}{l}1.96-04 \\
\text { per hour }\end{array}$ & & \begin{tabular}{|l} 
point \\
estimate
\end{tabular} & rupture & 0.01 & & $\begin{array}{l}\text { point } \\
\text { estimate }\end{array}$ & nupture & & & \\
\hline $\begin{array}{l}\text { vacuum } \\
\text { system }\end{array}$ & 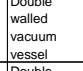 & vessel welds & & $\begin{array}{l}\text { vacuum } \\
\text { boundary } \\
\text { ben }\end{array}$ & $\begin{array}{l}\text { surface of } \\
\text { weld }\end{array}$ & continuous & RH Class 3 & & small leaks & \begin{tabular}{|l}
$\begin{array}{l}1.8 E-08 \\
\text { per moter-r. } \\
\text { hour }\end{array}$ \\
\end{tabular} & 10 & exponential & small leaks & $\begin{array}{l}1.98-04 \\
\text { per hour }\end{array}$ & & \begin{tabular}{|l} 
point \\
estimate
\end{tabular} & small leaks & 0.01 & & $\begin{array}{l}\text { point } \\
\text { sestimate } \\
\end{array}$ & small leaks & & & \\
\hline $\begin{array}{l}\text { Vacuum } \\
\text { system }\end{array}$ & $\begin{array}{l}\text { Double } \\
\text { walled } \\
\text { vacuum } \\
\text { vessel } \\
\text { vesel }\end{array}$ & vessel welds & & $\begin{array}{l}\text { vacuum } \\
\text { boundary }\end{array}$ & $\begin{array}{l}\text { 量uface of } \\
\text { weld }\end{array}$ & continuous & RH Class 3 & & large leaks & 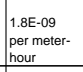 & 10 & exponential & large leaks & $\begin{array}{l}1.9 E-04 \\
\text { per hour }\end{array}$ & & \begin{tabular}{|l} 
point \\
estimate
\end{tabular} & large leaks & 0.01 & & $\begin{array}{l}\text { point } \\
\text { estimate }\end{array}$ & large leaks & & & \\
\hline $\begin{array}{l}\text { Vacuum } \\
\text { system }\end{array}$ & $\begin{array}{l}\text { Double } \\
\text { wallod } \\
\text { vacuum } \\
\text { vessel }\end{array}$ & wessel welds & & $\begin{array}{l}\text { vacuum } \\
\text { boundary }\end{array}$ & $\begin{array}{l}\text { 甚uface of } \\
\text { weld }\end{array}$ & continuous & RH Class 3 & & ruptures & \begin{tabular}{|l}
$\begin{array}{l}1.8 E-10 \\
\text { per moter-er- } \\
\text { hour }\end{array}$ \\
her
\end{tabular} & 10 & exponential & rupptures & 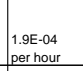 & & \begin{tabular}{|l} 
point \\
estimate
\end{tabular} & rupptures & 0.01 & & $\mid \begin{array}{l}\text { ponit } \\
\text { estimate }\end{array}$ & ruppures & & & \\
\hline $\begin{array}{l}\text { Vacuum } \\
\text { system }\end{array}$ & 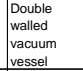 & 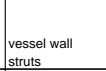 & & $\mid \begin{array}{l}\text { stucutural } \\
\text { susport }\end{array}$ & 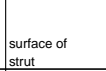 & |continuous & RH Class 3 & & $\begin{array}{l}\text { overstress } \\
\text { pess }\end{array}$ & & & & $\begin{array}{l}\text { Ooverstress } \\
\end{array}$ & $\begin{array}{l}1.96-04 \\
\text { per hour }\end{array}$ & & $\mid \begin{array}{l}\text { point } \\
\text { estimate }\end{array}$ & $\begin{array}{l}\text { Overstress } \\
\text { p }\end{array}$ & 0.01 & & \begin{tabular}{|l} 
point \\
estimate
\end{tabular} & $\begin{array}{l}\text { Overstress } \\
\end{array}$ & $\begin{array}{l}\text { Ee.0p per } \\
\text { demand }\end{array}$ & $\begin{array}{l}\text { unper } \\
\text { bound } \\
\text { autoted }\end{array}$ & \\
\hline $\begin{array}{l}\text { Vacuum } \\
\text { system }\end{array}$ & 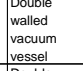 & $\begin{array}{l}\text { vessel wall } \\
\text { struts }\end{array}$ & & $\begin{array}{l}\substack{\text { structural } \\
\text { support }} \\
\text { s. }\end{array}$ & $\begin{array}{l}\text { surface of } \\
\text { strut }\end{array}$ & continuous & RH Class 3 & & fracture & $\begin{array}{l}1 \text { 1E-0 } \mathrm{ser} \\
\text { year }\end{array}$ & & Pexponential & fracture & $\begin{array}{l}1.9 E-04 \\
\text { per hour }\end{array}$ & & \begin{tabular}{|l}
$\begin{array}{l}\text { point } \\
\text { estimate }\end{array}$ \\
\end{tabular} & fracture & 0.01 & & \begin{tabular}{|l} 
point \\
essimate
\end{tabular} & Iracture & & & \\
\hline $\begin{array}{l}\text { Vacuum } \\
\text { system }\end{array}$ & \begin{tabular}{|l} 
Double \\
walled \\
vacuum \\
vessel
\end{tabular} & \begin{tabular}{|l} 
Neutron \\
shielding \\
plate inserts
\end{tabular} & & \begin{tabular}{|l} 
radiatian \\
shlieling
\end{tabular} & $\begin{array}{l}\text { surface of } \\
\text { plate }\end{array}$ & |continuous & RH Class 3 & & all modes & \begin{tabular}{|l}
$\begin{array}{l}1 E-02 \text { per } \\
\text { year }\end{array}$ \\
|
\end{tabular} & & $\begin{array}{l}\text { Chisquare } \\
\text { with two } \\
\text { degrees of } \\
\text { frredom }\end{array}$ & all modes & $\mid \begin{array}{l}1.96-04 \\
\text { per hour }\end{array}$ & & $\mid$\begin{tabular}{|c|c|c|c|c|} 
Postimate \\
ent
\end{tabular} & all modes & 0.01 & & $\begin{array}{l}\text { point } \\
\text { estimate }\end{array}$ & all modes & & & \\
\hline $\begin{array}{l}\text { Vacuum } \\
\text { system }\end{array}$ & $\begin{array}{l}\text { Double } \\
\text { walled } \\
\text { vacuum } \\
\text { vessel }\end{array}$ & \begin{tabular}{|l}
$\begin{array}{l}\text { vacuum } \\
\text { vessel } \\
\text { hatches }\end{array}$ \\
\end{tabular} & & $\mid \begin{array}{l}\text { sisalate } \\
\text { popts }\end{array}$ & $\begin{array}{l}\text { surface of } \\
\text { hatch }\end{array}$ & continuous & RH Class 2? & & all modes & $\mid \begin{array}{l}\text { year per } \\
\text { year }\end{array}$ & & $\begin{array}{l}\text { assumed } \\
\text { value }\end{array}$ & all modes & 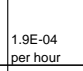 & & 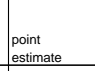 & all modes & 0.01 & & \begin{tabular}{|l} 
point \\
estimate
\end{tabular} & all modes & & & \\
\hline $\begin{array}{l}\text { Vacuum } \\
\text { system }\end{array}$ & $\begin{array}{l}\text { Double } \\
\text { walled } \\
\text { vacuum } \\
\text { vessel }\end{array}$ & $\begin{array}{l}\text { piping } \\
\text { penetrations }\end{array}$ & & $\begin{array}{l}\text { seal the } \\
\text { pipe } \\
\text { entries }\end{array}$ & 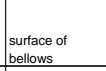 & continuous & RH Class 2 & & $\begin{array}{l}\text { smal extemal } \\
\text { leakage }\end{array}$ & $\begin{array}{l}5 \text { E- } 07 \text { per } \\
\text { hour }\end{array}$ & 10 & exponential & $\begin{array}{l}\text { small } \\
\text { external } \\
\text { leakage }\end{array}$ & $\begin{array}{l}4 \text { 4E-02 per } \\
\text { hour }\end{array}$ & & \begin{tabular}{|l} 
point \\
estimate
\end{tabular} & $\begin{array}{l}\text { small extermal } \\
\text { leakage }\end{array}$ & 0.01 & & $\begin{array}{l}\text { ponit } \\
\text { estimate }\end{array}$ & $\begin{array}{l}\text { small } \\
\text { external } \\
\text { leakage }\end{array}$ & & & \\
\hline $\begin{array}{l}\text { Vacuum } \\
\text { system }\end{array}$ & $\begin{array}{l}\text { Double } \\
\text { walled } \\
\text { vacuum } \\
\text { vessel }\end{array}$ & $\begin{array}{l}\text { piping } \\
\text { penetrations }\end{array}$ & & $\begin{array}{l}\text { seal the } \\
\text { pipe } \\
\text { entries }\end{array}$ & $\begin{array}{l}\text { surface of } \\
\text { bellows }\end{array}$ & continuous & RH Class 2 & & $\begin{array}{l}\text { large external } \\
\text { leakage }\end{array}$ & $\begin{array}{l}66-08 \text { per } \\
\text { hour }\end{array}$ & 10 & exponential & \begin{tabular}{|l} 
large \\
external \\
leakage
\end{tabular} & \begin{tabular}{|l} 
1E-02 per \\
hour
\end{tabular} & & \begin{tabular}{|l} 
point \\
estimate
\end{tabular} & $\begin{array}{l}\text { large extemal } \\
\text { leakage }\end{array}$ & 0.01 & & $\begin{array}{l}\text { point } \\
\text { estimate }\end{array}$ & $\begin{array}{l}\text { large } \\
\text { exemal } \\
\text { leakage }\end{array}$ & & & \\
\hline $\begin{array}{l}\text { Vacuum } \\
\text { system }\end{array}$ & \begin{tabular}{|l} 
Double \\
walled \\
vavumum \\
vessel \\
vessele
\end{tabular} & $\begin{array}{l}\begin{array}{l}\text { electrical } \\
\text { penetrations }\end{array} \\
\end{array}$ & & 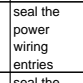 & $\begin{array}{l}\text { surface of the } \\
\text { penentation }\end{array}$ & continuous & RH Class 3 & & $\begin{array}{l}\text { external } \\
\text { leakages }\end{array}$ & \begin{tabular}{|l}
$5 E-04 \mathrm{per}$ \\
year
\end{tabular} & 100 & exponential & \begin{tabular}{|l} 
external \\
leakage
\end{tabular} & $\begin{array}{l}\text { 1E-02 per } \\
\text { hour }\end{array}$ & & \begin{tabular}{|l} 
point \\
estimate
\end{tabular} & $\begin{array}{l}\text { external } \\
\text { leakage }\end{array}$ & 0.01 & & $\begin{array}{l}\text { point } \\
\text { estimate }\end{array}$ & $\begin{array}{l}\text { external } \\
\text { leakage }\end{array}$ & & & \\
\hline $\begin{array}{l}\text { Vacuum } \\
\text { system }\end{array}$ & $\begin{array}{l}\text { Double } \\
\text { walled } \\
\text { vacuum } \\
\text { vessel } \\
\text { vesel }\end{array}$ & $\begin{array}{l}\begin{array}{l}\text { electrical } \\
\text { penetrations }\end{array} \\
\text {. }\end{array}$ & & $\begin{array}{l}\text { seal the } \\
\text { instrumen } \\
\text { twiting } \\
\text { entries }\end{array}$ & $\begin{array}{l}\text { surface of the } \\
\text { penentation }\end{array}$ & continuous & RH Class 3 & & $\begin{array}{l}\text { external } \\
\text { leakage }\end{array}$ & 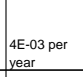 & 2.5 & exponential & $\begin{array}{l}\text { external } \\
\text { leakage }\end{array}$ & $\begin{array}{l}\text { 1E-02 per } \\
\text { hour }\end{array}$ & & \begin{tabular}{|l} 
point \\
estimate
\end{tabular} & $\begin{array}{l}\text { external } \\
\text { leakage }\end{array}$ & 0.01 & & $\begin{array}{l}\text { point } \\
\text { estimate }\end{array}$ & $\begin{array}{l}\text { external } \\
\text { leakage }\end{array}$ & & & \\
\hline $\begin{array}{l}\text { Vacuum } \\
\text { system }\end{array}$ & $\begin{array}{l}\text { Double } \\
\text { walled } \\
\text { vacuum } \\
\text { vessel }\end{array}$ & $\begin{array}{l}\text { opitical } \\
\text { penetrations }\end{array}$ & & \begin{tabular}{|l} 
seal \\
opical \\
viewing \\
ports
\end{tabular} & $\begin{array}{l}\text { surface of } \\
\text { pentertaion } \\
\text { puntain }\end{array}$ & continuous & RH Class 3 & & small leakage & \begin{tabular}{|l}
$1 E-02$ per \\
year
\end{tabular} & & exponential & \begin{tabular}{|l} 
small \\
leakege
\end{tabular} & \begin{tabular}{|l|l} 
1E-02 per \\
hour
\end{tabular} & & $\begin{array}{l}\text { point } \\
\text { estimate }\end{array}$ & small leakage & 0.01 & & $\begin{array}{l}\text { point } \\
\text { estimate }\end{array}$ & small leakage & & & \\
\hline $\begin{array}{l}\text { vacuum } \\
\text { System }\end{array}$ & $\begin{array}{l}\text { Vacuum } \\
\text { pumping }\end{array}$ & $\begin{array}{l}\text { Rough vacuum } \\
\text { pumps }\end{array}$ & & $\begin{array}{l}\text { Pump } \\
\text { 仵m atm } \\
\text { to } 1 \text { Pa }\end{array}$ & 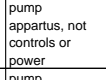 & Initermittent & RH Class 2 & & fail to operate & $\mid \begin{array}{l}1.5 E-05 \\
\text { per hour }\end{array}$ & 1.2 & exponential & $\begin{array}{l}\text { tail to } \\
\text { operate }\end{array}$ & $\begin{array}{l}\text { 3E-03 per } \\
\text { hour }\end{array}$ & & \begin{tabular}{|l} 
point \\
estimate
\end{tabular} & fail to operate & 0.1 & & $\begin{array}{l}\text { point } \\
\text { estimate }\end{array}$ & $\begin{array}{l}\text { tailto } \\
\text { operate }\end{array}$ & & & \\
\hline $\begin{array}{l}\text { Vacuum } \\
\text { system }\end{array}$ & \begin{tabular}{|l} 
Vacuum \\
pumping
\end{tabular} & $\begin{array}{l}\text { Rough vacuum } \\
\text { pumps }\end{array}$ & & $\begin{array}{l}\text { Pump } \\
\text { Prom atm } \\
\text { tom } 1 \text { ta }\end{array}$ & 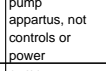 & |intermittent & RH Class 2 & & \begin{tabular}{|l} 
extemal \\
leakkage
\end{tabular} & $\begin{array}{l}5 \text { 5E.03 per } \\
\text { year }\end{array}$ & 10 & exponential & $\begin{array}{l}\text { external } \\
\text { leakage }\end{array}$ & $\begin{array}{l}\text { 3E-03 per } \\
\text { hour }\end{array}$ & & $\begin{array}{l}\text { point } \\
\text { estimate }\end{array}$ & \begin{tabular}{|} 
external \\
leakage
\end{tabular} & 0.1 & & $\begin{array}{l}\text { point } \\
\text { estimate }\end{array}$ & \begin{tabular}{|l} 
external \\
leakage
\end{tabular} & & & \\
\hline $\begin{array}{l}\text { Vacuum } \\
\text { System }\end{array}$ & \begin{tabular}{|l} 
Vacuum \\
pumping
\end{tabular} & Cryopumps & & 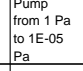 & 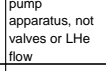 & $\begin{array}{l}\text { nearly } \\
\text { continuous }\end{array}$ & RH Class 2 & & fail to operatat & 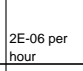 & & exponential & $\begin{array}{l}\text { 位 to to } \\
\text { operate }\end{array}$ & $\begin{array}{l}3 \text { 3E-03 per } \\
\text { hour }\end{array}$ & & 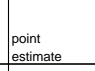 & failito operatat & 0.01 & & $\begin{array}{l}\text { point } \\
\text { estimate }\end{array}$ & $\begin{array}{l}\text { lati to } \\
\text { operate }\end{array}$ & & & \\
\hline
\end{tabular}


Table A-1. Vacuum System Data Table (continued).

\begin{tabular}{|c|c|c|c|c|c|c|c|c|c|c|c|c|c|c|c|c|c|c|c|c|c|c|c|}
\hline \multicolumn{4}{|c|}{ 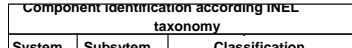 } & \multirow[b]{2}{*}{ Function } & \multirow[b]{2}{*}{\begin{tabular}{|l|} 
Component \\
boundaries
\end{tabular}} & \multirow[b]{2}{*}{\begin{tabular}{|c|} 
Operating \\
regime \\
\end{tabular}} & \multirow{2}{*}{\begin{tabular}{|l|} 
Maintenance \\
regime \\
\end{tabular}} & \multicolumn{16}{|c|}{ Into Failure Rates } \\
\hline & & \begin{tabular}{|l|} 
Classifica \\
Lev 1
\end{tabular} & Lev.2 & & & & & $\begin{array}{l}\text { Fail } \\
\text { Code }\end{array}$ & Pescription & \begin{tabular}{|l} 
Average \\
value
\end{tabular} & \begin{tabular}{|l|l|} 
Error \\
factor
\end{tabular} & \begin{tabular}{|l|} 
Type of \\
distributio \\
\end{tabular} & Description & \begin{tabular}{|l|} 
Average \\
value
\end{tabular} & \begin{tabular}{|l} 
Error \\
factor
\end{tabular} & \begin{tabular}{|l|} 
Type of \\
distribution
\end{tabular} & Description & \begin{tabular}{|l} 
Average \\
value \\
\end{tabular} & \begin{tabular}{|l|l|} 
Error \\
factor
\end{tabular} & \begin{tabular}{|l|} 
Type of \\
distributio
\end{tabular} & Description & \begin{tabular}{|l} 
Average \\
value
\end{tabular} & \begin{tabular}{|l|} 
Error \\
factor
\end{tabular} \\
\hline $\begin{array}{l}\text { Vacuum } \\
\text { system }\end{array}$ & $\begin{array}{l}\text { vacaum } \\
\text { pumping }\end{array}$ & Cryopumps & 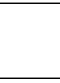 & $\begin{array}{l}\text { Pump } \\
\text { trom } 1 \mathrm{~Pa} \\
\text { to } 1 \text { 1 } 1005 \\
\text { Pa }\end{array}$ & $\begin{array}{l}\text { pump } \\
\text { apparatus, not } \\
\text { valves or LLe } \\
\text { Howw }\end{array}$ & $\begin{array}{l}\text { nearly } \\
\text { continuous }\end{array}$ & RH Class 2 & & $\begin{array}{l}\text { Leak into } \\
\text { vacuum } \\
\text { chamber }\end{array}$ & $\begin{array}{l}\begin{array}{l}22-05 \text { per } \\
\text { hour }\end{array} \\
\text { n }\end{array}$ & $1.7 \mathrm{C}$ & exponential & $\begin{array}{l}\text { Leak into } \\
\text { vacuum } \\
\text { chamber }\end{array}$ & $\begin{array}{l}3 \text { EE-03 per } \\
\text { hour }\end{array}$ & & $\begin{array}{l}\text { point } \\
\text { estimate }\end{array}$ & $\begin{array}{l}\text { Leak into } \\
\text { vacuum } \\
\text { chamber }\end{array}$ & 0.01 & & $\begin{array}{l}\text { point } \\
\text { estimate }\end{array}$ & $\begin{array}{l}\text { Leak into } \\
\text { vacuum } \\
\text { chamber }\end{array}$ & & \\
\hline $\begin{array}{l}\text { Vacuum } \\
\text { System }\end{array}$ & $\begin{array}{l}\text { Vacuum } \\
\text { pumping }\end{array}$ & $\begin{array}{l}\text { Vacuum } \\
\text { screens }\end{array}$ & & $\begin{array}{l}\begin{array}{l}\text { prevent } \\
\text { foreign } \\
\text { material } \\
\text { intrusion }\end{array} \\
\end{array}$ & $\begin{array}{l}\text { screen } \\
\text { surface }\end{array}$ & \begin{tabular}{|l} 
nearly \\
continuous
\end{tabular} & RH Class 2 & & $\begin{array}{l}\text { internal } \\
\text { leakage }\end{array}$ & $\begin{array}{l}2 \text { 2E-06 per } \\
\text { hour }\end{array}$ & 4.7 & exponential & $\begin{array}{l}\text { intemal } \\
\text { leakage }\end{array}$ & $\begin{array}{l}9.11-02 \\
\text { per hour }\end{array}$ & & $\begin{array}{l}\text { arithmetic } \\
\text { average and } \\
\text { loutiers }\end{array}$ & $\begin{array}{l}\text { 仿位al } \\
\text { leakage }\end{array}$ & 0.01 & & $\begin{array}{l}\text { point } \\
\text { estimate }\end{array}$ & $\begin{array}{l}\text { internal } \\
\text { leakage }\end{array}$ & & \\
\hline $\begin{array}{l}\begin{array}{l}\text { Vacuum } \\
\text { system }\end{array} \\
\text { s. }\end{array}$ & $\begin{array}{l}\text { vacuum } \\
\text { pumping }\end{array}$ & $\begin{array}{l}\text { Vacuum } \\
\text { screens }\end{array}$ & & $\begin{array}{l}\text { prevent } \\
\text { foreignt } \\
\text { material } \\
\text { intrusion }\end{array}$ & $\begin{array}{l}\text { screen } \\
\text { surface }\end{array}$ & $\begin{array}{l}\text { nearly } \\
\text { continuous }\end{array}$ & RH Class 2 & & plugging & $\begin{array}{l}9.9 E-06 \\
\text { per hour }\end{array}$ & & exponential & plugging & $\begin{array}{l}9.11-02 \\
\text { per hour }\end{array}$ & & \begin{tabular}{|l}
$\begin{array}{l}\text { arithmetic } \\
\text { average and } \\
\text { foutiers }\end{array}$ \\
\end{tabular} & plugging & 0.01 & & $\begin{array}{l}\text { point } \\
\text { festimate }\end{array}$ & plugging & & \\
\hline $\begin{array}{l}\begin{array}{l}\text { Vacuum } \\
\text { system }\end{array} \\
\end{array}$ & $\begin{array}{l}\text { Vacuum } \\
\text { pumping }\end{array}$ & $\begin{array}{l}\text { Vacuum } \\
\text { screens }\end{array}$ & & 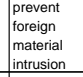 & $\begin{array}{l}\text { screen } \\
\text { surface }\end{array}$ & $\begin{array}{l}\begin{array}{l}\text { nearly } \\
\text { continuous }\end{array} \\
\end{array}$ & RH Class 2 & & $\begin{array}{l}\text { intermal } \\
\text { rupure }\end{array}$ & 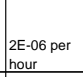 & 4.7 & exponential & $\begin{array}{l}\text { intemal } \\
\text { rupture }\end{array}$ & $\begin{array}{l}\begin{array}{l}7 \text { E-.2 per } \\
\text { hour }\end{array} \\
\text { hen }\end{array}$ & & \begin{tabular}{|l}
$\begin{array}{l}\text { arithmetic } \\
\text { average and } \\
\text { outhiers }\end{array}$ \\
\end{tabular} & $\begin{array}{l}\text { internal } \\
\text { rupture }\end{array}$ & 0.01 & & \begin{tabular}{|l} 
point \\
estimate
\end{tabular} & $\begin{array}{l}\text { internal } \\
\text { ruputure }\end{array}$ & & \\
\hline $\begin{array}{l}\begin{array}{l}\text { Vacuum } \\
\text { system }\end{array} \\
\text {. }\end{array}$ & $\begin{array}{l}\text { Vacuum } \\
\text { pumping }\end{array}$ & $\begin{array}{l}\begin{array}{l}\text { Vacuum } \\
\text { valves }\end{array} \\
\text { val }\end{array}$ & & \begin{tabular}{|l} 
isolate \\
vacuum \\
lines
\end{tabular} & $\begin{array}{l}\text { value surface, } \\
\text { innluder } \\
\text { operator but } \\
\text { not controls }\end{array}$ & intermittent & RH Class 2 & & $\begin{array}{l}\text { spurious change } \\
\text { of position }\end{array}$ & $\begin{array}{l}\begin{array}{l}3 \text { 3E-06 per } \\
\text { hour }\end{array} \\
\text { nat }\end{array}$ & & exponential & $\begin{array}{l}\text { spurious } \\
\text { change of } \\
\text { postition }\end{array}$ & $\begin{array}{l}5 \text { EE-02 per } \\
\text { hour }\end{array}$ & & \begin{tabular}{|l|}
$\begin{array}{l}\text { arithmetic } \\
\text { avergae and } \\
\text { outhiers }\end{array}$ \\
\end{tabular} & $\begin{array}{l}\text { spurious } \\
\text { change of } \\
\text { possition }\end{array}$ & 0.1 & & $\begin{array}{l}\text { ponit } \\
\text { estimate }\end{array}$ & $\begin{array}{l}\begin{array}{l}\text { spurious } \\
\text { change of } \\
\text { position }\end{array} \\
\text { int }\end{array}$ & & \\
\hline $\begin{array}{l}\begin{array}{l}\text { Vacuum } \\
\text { system }\end{array} \\
\text { s. }\end{array}$ & $\begin{array}{l}\text { Vacuum } \\
\text { pumping }\end{array}$ & $\begin{array}{l}\text { Vacuum } \\
\text { valves }\end{array}$ & & $\begin{array}{l}\begin{array}{l}\text { isolate } \\
\text { vacuum } \\
\text { lines }\end{array} \\
\end{array}$ & $\begin{array}{l}\text { vave surface, } \\
\text { includel } \\
\text { operator but } \\
\text { not controls }\end{array}$ & intermittent & RH Class 2 & & $\begin{array}{l}\text { external } \\
\text { leakage }\end{array}$ & 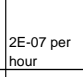 & & exponential & \begin{tabular}{|l} 
external \\
leakage
\end{tabular} & $\begin{array}{l}5 \text { E-.02 per } \\
\text { hour }\end{array}$ & & \begin{tabular}{|l}
$\begin{array}{l}\text { arithmetic } \\
\text { avergage and } \\
\text { poutiers }\end{array}$ \\
\end{tabular} & $\begin{array}{l}\text { external } \\
\text { leakage }\end{array}$ & 0.1 & & $\begin{array}{l}\text { point } \\
\text { estimate }\end{array}$ & $\begin{array}{l}\text { extemal } \\
\text { leakage }\end{array}$ & & \\
\hline $\begin{array}{l}\begin{array}{l}\text { Vacuum } \\
\text { system }\end{array} \\
\text { s. }\end{array}$ & $\begin{array}{l}\text { Vacuum } \\
\text { pumping }\end{array}$ & $\begin{array}{l}\text { Vacuum } \\
\text { valves }\end{array}$ & & \begin{tabular}{|l|l}
$\begin{array}{l}\text { isolate } \\
\text { vacuum } \\
\text { lines }\end{array}$ \\
\end{tabular} & $\begin{array}{l}\text { valve surface, } \\
\text { innilude } \\
\text { operator but } \\
\text { not controls }\end{array}$ & intermittent & RH Class 2 & & $\begin{array}{l}\text { intermal } \\
\text { leakage }\end{array}$ & $\begin{array}{l}3 \text { BE-06 per } \\
\text { hour }\end{array}$ & 30 & exponential & $\begin{array}{l}\text { intemal } \\
\text { leakage }\end{array}$ & $\begin{array}{l}5 \text { E-.02 per } \\
\text { hour }\end{array}$ & & $\begin{array}{l}\text { arithmetic } \\
\text { avergage and } \\
\text { autitiers }\end{array}$ & 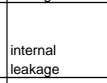 & 0.1 & & \begin{tabular}{|l} 
point \\
estimate
\end{tabular} & $\begin{array}{l}\text { internal } \\
\text { leakage }\end{array}$ & & \\
\hline $\begin{array}{l}\text { Vacuum } \\
\text { system }\end{array}$ & $\begin{array}{l}\text { Vacuum } \\
\text { pumping }\end{array}$ & $\begin{array}{l}\text { Voacum } \\
\text { vaves }\end{array}$ & & $\begin{array}{l}\text { isolate } \\
\text { vacuum } \\
\text { lines }\end{array}$ & $\begin{array}{l}\text { value surface, } \\
\text { innluder } \\
\text { oporator but } \\
\text { not controls }\end{array}$ & lintermittent & RH Class 2 & & $\begin{array}{l}\text { fail to change } \\
\text { postition on } \\
\text { demand }\end{array}$ & & & & \begin{tabular}{|l} 
fail to \\
change \\
position on \\
demand
\end{tabular} & \begin{tabular}{|l}
5 EE-02 per \\
hour
\end{tabular} & & \begin{tabular}{|l}
$\begin{array}{l}\text { arithmetic } \\
\text { average and } \\
\text { outtiers }\end{array}$ \\
\end{tabular} & $\begin{array}{l}\begin{array}{l}\text { tail to change } \\
\text { position on } \\
\text { demand }\end{array} \\
\text { denand }\end{array}$ & 0.1 & & $\mid \begin{array}{l}\text { point } \\
\text { estimate }\end{array}$ & $\begin{array}{l}\text { fail to change } \\
\text { position on } \\
\text { demand }\end{array}$ & $\begin{array}{l}\text { Ee-04 per } \\
\text { demand }\end{array}$ & \\
\hline $\begin{array}{l}\text { Vacuum } \\
\text { System }\end{array}$ & $\begin{array}{l}\begin{array}{l}\text { Pressure } \\
\text { suppressio } \\
\text { n system }\end{array} \\
\end{array}$ & \begin{tabular}{|l} 
Vacuum \\
vessel \\
suppression \\
tanks
\end{tabular} & & $\begin{array}{l}\text { condense } \\
\text { stitam to } \\
\text { liquid }\end{array}$ & tank surface & standby & hands-on & & leakage & $\begin{array}{l}1.5 E-05 \\
\text { per year }\end{array}$ & & exponential & leakage & \begin{tabular}{|l}
$4 \begin{array}{l}4-03 \\
\text { hour }\end{array}$ \\
her
\end{tabular} & & $\begin{array}{l}\text { arithmetic } \\
\text { average and } \\
\text { outiliers }\end{array}$ & leakage & 0.01 & & $\begin{array}{l}\text { point } \\
\text { estimate }\end{array}$ & leakage & & \\
\hline $\begin{array}{l}\text { Vacuum } \\
\text { System }\end{array}$ & $\begin{array}{l}\begin{array}{l}\text { Pressure } \\
\text { suppressio } \\
\text { n system }\end{array} \\
\end{array}$ & $\begin{array}{l}\text { vacuumel } \\
\text { vusperession } \\
\text { tanks }\end{array}$ & & 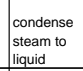 & tank surface & standby & hands-on & & rupture & 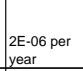 & 1.2 & exponential & rupture & $\mid \begin{array}{l}4 \begin{array}{l}4-03 \\
\text { hour }\end{array} \\
\text { her }\end{array}$ & & \begin{tabular}{|l}
$\mid \begin{array}{l}\text { arithmetic } \\
\text { average and } \\
\text { outtiers }\end{array}$ \\
\end{tabular} & frupture & 0.01 & & $\mid \begin{array}{l}\text { point } \\
\text { estimate }\end{array}$ & rupture & & \\
\hline $\begin{array}{l}\text { Vacuum } \\
\text { System }\end{array}$ & $\begin{array}{l}\begin{array}{l}\text { Pressure } \\
\text { suppressio } \\
\text { n system }\end{array} \\
\end{array}$ & \begin{tabular}{|l|} 
Rupture disks \\
to \\
suppression \\
tanks
\end{tabular} & & 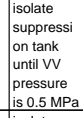 & $\begin{array}{l}\text { rupture disk } \\
\text { unit }\end{array}$ & standby & hands-on & & fail to open & & & & fail to open & $\begin{array}{l}4 \begin{array}{l}46-03 \\
\text { hour }\end{array} \\
\text { her }\end{array}$ & 2.2. & $\begin{array}{l}\text { arithmetic } \\
\text { avergate and } \\
\text { outhiers }\end{array}$ & fail to open & 0.01 & & $\begin{array}{l}\text { point } \\
\text { estimate }\end{array}$ & fail to open & $\begin{array}{l}\text { 1E-04 per } \\
\text { demand }\end{array}$ & \\
\hline $\begin{array}{l}\begin{array}{l}\text { Vacuum } \\
\text { system }\end{array} \\
\end{array}$ & $\begin{array}{l}\begin{array}{l}\text { Pressure } \\
\text { suppressio } \\
\text { n system }\end{array} \\
\end{array}$ & \begin{tabular}{|l} 
Rupture disks \\
to \\
suppression \\
tanks
\end{tabular} & & 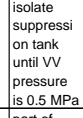 & $\begin{array}{l}\begin{array}{l}\text { rupture disk } \\
\text { unit }\end{array} \\
\end{array}$ & standby & hands-on & & leakage & $\begin{array}{l}\begin{array}{l}22-06 \\
\text { hour per }\end{array} \\
\text { hour }\end{array}$ & & exponential & leakage & $\mid \begin{array}{l}\text { EE-01 per } \\
\text { hour }\end{array}$ & & $\begin{array}{l}\mid \begin{array}{l}\text { assumed } \\
\text { values }\end{array} \\
\text { val }\end{array}$ & leakage & 0.01 & & 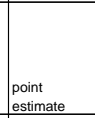 & |leakage & & \\
\hline $\begin{array}{l}\text { Vacuum } \\
\text { System }\end{array}$ & $\begin{array}{l}\text { Vacuum } \\
\text { pumping }\end{array}$ & Vacuum ducts & & $\begin{array}{l}\text { part of } \\
\text { vacuum } \\
\text { boundary }\end{array}$ & $\begin{array}{l}\text { surface of } \\
\text { duct }\end{array}$ & continuous & RH Class 3 & & leakage & $\begin{array}{l}\text { E-.08 per } \\
\text { hour } \\
\text { meter }\end{array}$ & 30 & exponential & leakage & \begin{tabular}{|l} 
7.4E-04 \\
per hour
\end{tabular} & & $\begin{array}{l}\text { point } \\
\text { estimate }\end{array}$ & leakage & 0.01 & & $\begin{array}{l}\text { point } \\
\text { estimate }\end{array}$ & leakage & & \\
\hline $\begin{array}{l}\text { Vacuum } \\
\text { System }\end{array}$ & $\begin{array}{l}\text { Vacuum } \\
\text { pumping }\end{array}$ & Vacuum ducts & & $\begin{array}{l}\text { part of } \\
\text { vacuum } \\
\text { boundary }\end{array}$ & $\begin{array}{l}\text { surface of } \\
\text { duct }\end{array}$ & continuous & RH Class 3 & & rupture & $\begin{array}{l}\text { E-10.10er } \\
\text { hour } \\
\text { meter }\end{array}$ & 30 & exponential & rupture & \begin{tabular}{|l}
$7.4 E-04$ \\
per hour
\end{tabular} & & $\begin{array}{l}\text { point } \\
\text { estimate }\end{array}$ & rupture & 0.01 & & $\begin{array}{l}\text { point } \\
\text { estimate }\end{array}$ & rupture & & \\
\hline $\begin{array}{l}\text { Vacuum } \\
\text { System }\end{array}$ & $\begin{array}{l}\text { Vacuum } \\
\text { pumping }\end{array}$ & $\begin{array}{l}\begin{array}{l}\text { High vacuum } \\
\text { gauges }\end{array} \\
\end{array}$ & & $\begin{array}{l}\text { Manontior } \\
\text { vacuum } \\
\text { pressure }\end{array}$ & $\begin{array}{l}\text { gauge unit } \\
\text { gitself }\end{array}$ & $\begin{array}{l}\begin{array}{l}\text { nearly } \\
\text { continuous }\end{array} \\
\end{array}$ & RH Class 2 & & fail to operate & $\begin{array}{l}66-03 \text { per } \\
\text { year }\end{array}$ & 2.2. & exponential & $\begin{array}{l}\text { tail to } \\
\text { operate }\end{array}$ & $\begin{array}{l}0.125 \mathrm{per} \\
\text { hour }\end{array}$ & & \begin{tabular}{|l} 
point \\
estimate
\end{tabular} & fail to operate & 0.1 & & $\begin{array}{l}\begin{array}{l}\text { point } \\
\text { estimate }\end{array} \\
\text { ent }\end{array}$ & \begin{tabular}{|l} 
fail to \\
operate
\end{tabular} & & \\
\hline $\begin{array}{l}\text { Vacuum } \\
\text { System }\end{array}$ & \begin{tabular}{|l}
$\begin{array}{l}\text { Vacuum } \\
\text { pumping }\end{array}$ \\
pula
\end{tabular} & $\begin{array}{l}\text { High vacuum } \\
\text { gauges }\end{array}$ & & $\begin{array}{l}\text { Monotitur } \\
\text { vacuum } \\
\text { pressure }\end{array}$ & $\begin{array}{l}\text { gauge unit } \\
\text { itself }\end{array}$ & \begin{tabular}{|l} 
nearly \\
continuous
\end{tabular} & RH Class 2 & & leakage & $\begin{array}{l}66-03 \text { per } \\
\text { year }\end{array}$ & 2.2. & exponential & leakage & $\begin{array}{l}0.125 \mathrm{per} \\
\text { hour }\end{array}$ & & \begin{tabular}{|l} 
point \\
estimate
\end{tabular} & leakage & 0.1 & & $\begin{array}{l}\text { point } \\
\text { estimate }\end{array}$ & leakage & & \\
\hline $\begin{array}{l}\text { Vacuum } \\
\text { system }\end{array}$ & $\begin{array}{l}\text { Vacuum } \\
\text { pumping }\end{array}$ & \begin{tabular}{|l|}
$\begin{array}{l}\text { Rough vacuum } \\
\text { gauges }\end{array}$ \\
\end{tabular} & & $\mid \begin{array}{l}\text { Monotitur } \\
\text { vacuum } \\
\text { pressure } \\
\text { Mesitrer }\end{array}$ & $\begin{array}{l}\substack{\text { gauge unit } \\
\text { itself }} \\
\end{array}$ & intermittent & RH Class 2 & & fail to operate & $\begin{array}{l}\text { 1E-04 per } \\
\text { hour }\end{array}$ & 10 & exponential & $\begin{array}{l}\text { fail to } \\
\text { operate }\end{array}$ & $\begin{array}{l}0.125 \text { per } \\
\text { hour }\end{array}$ & & \begin{tabular}{|l} 
point \\
estimate
\end{tabular} & fail to operate & 0.1 & & $\begin{array}{l}\text { point } \\
\text { estimate }\end{array}$ & $\begin{array}{l}\text { fail to } \\
\text { operate }\end{array}$ & & \\
\hline $\begin{array}{l}\begin{array}{l}\text { Vacuum } \\
\text { System }\end{array} \\
\end{array}$ & $\begin{array}{l}\text { Vacuum } \\
\text { pumping }\end{array}$ & $\begin{array}{l}\text { Rough vacuum } \\
\text { gauges }\end{array}$ & & $\mid \begin{array}{l}\text { Monitior } \\
\text { vacuum } \\
\text { pressure }\end{array}$ & \begin{tabular}{|l} 
gauge unit \\
itself
\end{tabular} & $\begin{array}{l}\text { nearly } \\
\text { continuous }\end{array}$ & RH Class 2 & & leakage & \begin{tabular}{|l}
$\begin{array}{l}\text { E-.03 per } \\
\text { year }\end{array}$ \\
\end{tabular} & & exponential & leakage & $\begin{array}{l}0.125 \text { per } \\
\text { hour }\end{array}$ & & \begin{tabular}{|l} 
point \\
estimate
\end{tabular} & leakage & 0.1 & & $\begin{array}{l}\text { point } \\
\text { estimate }\end{array}$ & leakage & & \\
\hline & & & & & & & & & & & & & & & & & & & & & & & \\
\hline
\end{tabular}


Table A-2. Heat Transfer System Data Table.

\begin{tabular}{|c|c|c|c|c|c|c|c|c|c|c|c|c|c|c|c|c|c|c|c|c|c|c|c|}
\hline \multicolumn{4}{|c|}{\begin{tabular}{|c|} 
Component identification according INEL \\
taxonomy
\end{tabular}} & \multirow{3}{*}{ Function } & \multirow{3}{*}{\begin{tabular}{|l|} 
Component \\
boundaries
\end{tabular}} & \multirow{3}{*}{\begin{tabular}{|c|} 
operatin \\
gegime \\
\end{tabular}} & \multirow{3}{*}{\begin{tabular}{|l} 
Maintenance \\
regime \\
\end{tabular}} & \multirow[b]{3}{*}{ Description } & \multirow{3}{*}{\begin{tabular}{|l} 
Average \\
value
\end{tabular}} & \multirow{3}{*}{$\begin{array}{l}\text { Error } \\
\text { tactor }\end{array}$} & \multirow{3}{*}{\begin{tabular}{|l} 
Type of \\
distrituutio \\
$n$
\end{tabular}} & \multirow[b]{3}{*}{ Description } & \multirow{3}{*}{\begin{tabular}{|l} 
Average \\
value
\end{tabular}} & \multirow{3}{*}{\begin{tabular}{|l} 
Error \\
factor
\end{tabular}} & \multirow{3}{*}{\begin{tabular}{|l|} 
Type of \\
distribution \\
\end{tabular}} & \multirow[b]{3}{*}{ Description } & \multirow{3}{*}{\begin{tabular}{|l} 
Average \\
value \\
\end{tabular}} & \multirow{3}{*}{\begin{tabular}{|l} 
Error \\
factor
\end{tabular}} & \multirow{3}{*}{\begin{tabular}{|l} 
Type of \\
distributio \\
$n$
\end{tabular}} & \multirow[b]{3}{*}{ Description } & \multirow{3}{*}{\begin{tabular}{|l} 
Average \\
value \\
\end{tabular}} & \multirow{3}{*}{$\begin{array}{l}\text { Error } \\
\text { factor }\end{array}$} & \multirow{3}{*}{$\begin{array}{l}\text { Type of } \\
\text { distributior }\end{array}$} \\
\hline System & Subsytem & $\begin{array}{l}\text { Compone } \\
\text { Classifica }\end{array}$ & & & & & & & & & & & & & & & & & & & & & \\
\hline & & Lev.1 & Lev. 2 & & & & & & & & & & & & & & & & & & & & \\
\hline 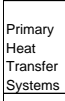 & \begin{tabular}{|l} 
heat \\
transter \\
loops
\end{tabular} & \begin{tabular}{|l} 
ex-vessel \\
coolant piping
\end{tabular} & & \begin{tabular}{|l|} 
Route \\
coolant to \\
and from \\
vacuum \\
vessel
\end{tabular} & pipe wall & $\begin{array}{l}\text { intermite } \\
\text { nt }\end{array}$ & hands-on & $\begin{array}{l}\text { Leakage for } \\
\text { small diameter } \\
<<76 \text { mm diaa }\end{array}$ & $\begin{array}{l}\begin{array}{l}7 E-10 \text { per } \\
\text { meter- } \\
\text { hour }\end{array} \\
\end{array}$ & & exponential & $\begin{array}{l}\begin{array}{l}\text { Leakage for } \\
\text { small } \\
\text { diameter } \\
\text { ( }<76 \mathrm{~mm} \text { dia) }\end{array} \\
\end{array}$ & \begin{tabular}{|l}
4 EE-03 per \\
hour
\end{tabular} & & assumed value & $\begin{array}{l}\begin{array}{l}\text { Leakage for } \\
\text { small } \\
\text { diameter (<76 } \\
\text { mm dia) }\end{array} \\
\end{array}$ & 0.01 & & $\mid \begin{array}{l}\text { point } \\
\text { estimate }\end{array}$ & $\begin{array}{l}\begin{array}{l}\text { Leakage for } \\
\text { small } \\
\text { diameter } k 76 \\
\text { mim dia) }\end{array} \\
\end{array}$ & & & \\
\hline $\begin{array}{l}\begin{array}{l}\text { Primary } \\
\text { heat } \\
\text { transter } \\
\text { systems }\end{array} \\
\text { sef }\end{array}$ & \begin{tabular}{|l} 
heat \\
transter \\
loops
\end{tabular} & $\begin{array}{l}\text { ex-vessel } \\
\text { coolant piping }\end{array}$ & & \begin{tabular}{|l|}
$\begin{array}{l}\text { Route } \\
\text { coolant to } \\
\text { and from } \\
\text { vacuum } \\
\text { vessel }\end{array}$ \\
\end{tabular} & pipe wall & $\begin{array}{l}\text { lintermite } \\
\text { nt }\end{array}$ & hands-on & $\begin{array}{l}\begin{array}{l}\text { Rupture for } \\
\text { small diameter } \\
k<76 \text { mm dia) }\end{array} \\
\end{array}$ & $\begin{array}{l}\begin{array}{l}E E-11 \text { per } \\
\text { hour- } \\
\text { meter }\end{array} \\
\end{array}$ & 30 & exponential & $\begin{array}{l}\text { Rupture for } \\
\text { small } \\
\text { diameter } \\
\text { ( }<76 \mathrm{~mm} \text { dia) }\end{array}$ & $\begin{array}{l}4 \text { EE-03 per } \\
\text { hour }\end{array}$ & & assumed value & \begin{tabular}{|l}
$\begin{array}{l}\text { Rupture for } \\
\text { small } \\
\text { diameter (<76 } \\
\text { mm dia) }\end{array}$ \\
\end{tabular} & 0.01 & & \begin{tabular}{|l} 
point \\
estimate
\end{tabular} & \begin{tabular}{|l}
$\begin{array}{l}\text { Rupture for } \\
\text { small } \\
\text { diameter }<76 \\
\text { mim dia) }\end{array}$ \\
\end{tabular} & & & \\
\hline $\begin{array}{l}\text { Primary } \\
\text { heat } \\
\text { transter } \\
\text { systems }\end{array}$ & \begin{tabular}{|l} 
heat \\
transter \\
loops
\end{tabular} & \begin{tabular}{|l} 
ex-vessel \\
coolant piping
\end{tabular} & & \begin{tabular}{|l|} 
Route \\
coolant to \\
and from \\
vacuum \\
vessel
\end{tabular} & pipe wall & $\begin{array}{l}\text { intermitite } \\
n t\end{array}$ & hands-on & 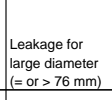 & $\begin{array}{l}2.5 E-10 \\
\text { per hour- } \\
\text { meter }\end{array}$ & & exponential & $\begin{array}{l}\text { Leakage for } \\
\text { large } \\
\text { diameter (= } \\
\text { or }>76 \mathrm{~mm})\end{array}$ & \begin{tabular}{|l}
4 EE-03 per \\
hour
\end{tabular} & & assumed value & $\begin{array}{l}\text { Leakage for } \\
\text { larage diameter } \\
(=0 \mathrm{or}>76 \mathrm{~mm})\end{array}$ & 0.01 & & \begin{tabular}{|l} 
point \\
estimate
\end{tabular} & $\begin{array}{l}\text { Leakage for } \\
\text { large } \\
\text { diameter }(= \\
\text { or }>76 \mathrm{~mm})\end{array}$ & & & \\
\hline $\begin{array}{l}\text { Primary } \\
\text { heat } \\
\text { transter } \\
\text { systems }\end{array}$ & \begin{tabular}{|l} 
heat \\
transter \\
loops
\end{tabular} & \begin{tabular}{|l} 
ex-vessel \\
coolant piping
\end{tabular} & & \begin{tabular}{|l|l} 
Route \\
coolant to \\
and from \\
vacuum \\
vessel
\end{tabular} & pipe wall & $\begin{array}{l}\text { intermitte } \\
n t\end{array}$ & hands-on & 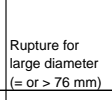 & $\begin{array}{l}2.5 E-11 \\
\text { per hour- } \\
\text { meter }\end{array}$ & 30 & exponential & $\begin{array}{l}\text { Rupture for } \\
\text { large } \\
\text { diameter (= } \\
\text { or }>76 \mathrm{~mm})\end{array}$ & \begin{tabular}{|l}
4 EE-03 per \\
hour
\end{tabular} & & assumed value & $\begin{array}{l}\begin{array}{l}\text { Rupture for } \\
\text { larage diameter } \\
(=0 \mathrm{c}>76 \mathrm{~mm})\end{array} \\
\text { (a) }\end{array}$ & 0.01 & & \begin{tabular}{|l} 
point \\
estimate
\end{tabular} & \begin{tabular}{|l} 
Rupture for \\
large \\
diameter $(=$ \\
or $>76 \mathrm{~mm})$
\end{tabular} & & & \\
\hline $\begin{array}{l}\text { Primary } \\
\text { Heat } \\
\text { Transter } \\
\text { Systems }\end{array}$ & \begin{tabular}{|l} 
heat \\
transter \\
loops
\end{tabular} & Guard pipes & & \begin{tabular}{|l} 
Double \\
containme \\
nt tof \\
coolant \\
lines
\end{tabular} & $\begin{array}{l}\text { pipe wall and } \\
\text { centering } \\
\text { devices }\end{array}$ & standby & RH Class 2? & Leakage & & & & Leakage & \begin{tabular}{|l}
4 EE-03 per \\
hour
\end{tabular} & & assumed value & Leakage & 0.01 & & \begin{tabular}{|l} 
point \\
estimate
\end{tabular} & Leakage & $\begin{array}{l}1 \text { 1E-01 per } \\
\text { demand }\end{array}$ & 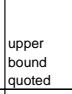 & \\
\hline $\begin{array}{l}\begin{array}{l}\text { Primary } \\
\text { heat } \\
\text { transter } \\
\text { systems }\end{array} \\
\end{array}$ & $\begin{array}{l}\text { heat } \\
\text { transter } \\
\text { loops }\end{array}$ & Guard pipes & & \begin{tabular}{|l}
$\mid \begin{array}{l}\text { Double } \\
\text { containme } \\
\text { nt of } \\
\text { coolant } \\
\text { lines }\end{array}$ \\
\end{tabular} & $\begin{array}{l}\mid \begin{array}{l}\text { pipe wall and } \\
\text { centeting } \\
\text { devices }\end{array} \\
\end{array}$ & standby & RH Class 2? & fuppture & & & & ruppture & 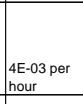 & & assumed value & rupture & 0.01 & & \begin{tabular}{|l} 
point \\
estimate
\end{tabular} & ruppture & $\begin{array}{l}1 \mathrm{E}-02 \text { per } \\
\text { demand }\end{array}$ & \begin{tabular}{|l}
$\mid \begin{array}{l}\text { upper } \\
\text { bound } \\
\text { quuted }\end{array}$ \\
\end{tabular} & \\
\hline $\begin{array}{l}\text { Primary } \\
\text { Heat } \\
\text { Transfer } \\
\text { Systems } \\
\text { Ditem }\end{array}$ & \begin{tabular}{|l} 
neat \\
transter \\
loops
\end{tabular} & $\begin{array}{l}\begin{array}{l}\text { Centrifugal } \\
\text { pumps }\end{array} \\
\end{array}$ & & \begin{tabular}{|l} 
Circulate \\
coolant \\
for heat \\
transter
\end{tabular} & $\begin{array}{l}\text { pumpunit, not } \\
\text { poover or } \\
\text { controls }\end{array}$ & $\begin{array}{l}\text { intermitte } \\
\text { nt }\end{array}$ & hands-on & reduced output & $\begin{array}{l}1.4 E-05 \\
\text { per hour }\end{array}$ & 1.3 & exponential & $\begin{array}{l}\text { reduced } \\
\text { output }\end{array}$ & $\begin{array}{l}8.3 E-02 \\
\text { per hour }\end{array}$ & 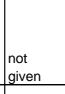 & \begin{tabular}{|l} 
point \\
estimate
\end{tabular} & reduced output & 0.1 & & \begin{tabular}{|l} 
point \\
estimate
\end{tabular} & $\begin{array}{l}\text { reduced } \\
\text { output }\end{array}$ & & & \\
\hline 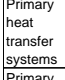 & \begin{tabular}{|l}
$\begin{array}{l}\text { heat } \\
\text { transfer } \\
\text { loops }\end{array}$ \\
\end{tabular} & $\begin{array}{l}\text { Centrifugal } \\
\text { pumps }\end{array}$ & & 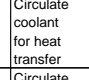 & $\begin{array}{l}\text { pumpunit, not } \\
\text { poover or } \\
\text { controls }\end{array}$ & $\begin{array}{l}\text { intermitte } \\
\text { nt }\end{array}$ & hands-on & fail to run & $\begin{array}{l}4 \text { E- }-06 \text { per } \\
\text { hour }\end{array}$ & 1.5 & exponential & fail to run & \begin{tabular}{|l}
$6.66-02$ \\
per hour
\end{tabular} & 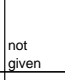 & \begin{tabular}{|l} 
point \\
estimate
\end{tabular} & fail to run & 0.1 & & \begin{tabular}{|l} 
point \\
estimate
\end{tabular} & fail to run & & & \\
\hline $\begin{array}{l}\text { 位任ary } \\
\text { transter } \\
\text { systems } \\
\text { ystems }\end{array}$ & \begin{tabular}{|l}
$\begin{array}{l}\text { neat } \\
\text { transter } \\
\text { loops }\end{array}$ \\
\end{tabular} & $\begin{array}{l}\begin{array}{l}\text { Centrifugal } \\
\text { pumps }\end{array} \\
\end{array}$ & & 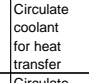 & $\begin{array}{l}\text { pump unit, not } \\
\text { power or } \\
\text { controls } \\
\end{array}$ & $\begin{array}{l}\text { intermitte } \\
\text { nt }\end{array}$ & hands-on & $\begin{array}{l}\text { extemal } \\
\text { leakage }\end{array}$ & $\begin{array}{l}3.6 E-05 \\
\text { per hour }\end{array}$ & 1.2 & exponential & $\begin{array}{l}\text { external } \\
\text { leakage }\end{array}$ & $\begin{array}{l}22-01 \text { per } \\
\text { hour }\end{array}$ & $\begin{array}{l}\text { not } \\
\text { given }\end{array}$ & \begin{tabular}{|l} 
point \\
estimate
\end{tabular} & $\begin{array}{l}\text { external } \\
\text { leakage }\end{array}$ & 0.1 & & \begin{tabular}{|l} 
point \\
estimate
\end{tabular} & \begin{tabular}{|l} 
external \\
leakage
\end{tabular} & & & \\
\hline $\begin{array}{l}\text { Primary } \\
\text { heat } \\
\text { transter } \\
\text { systems }\end{array}$ & \begin{tabular}{|l} 
heat \\
transfer \\
loops
\end{tabular} & $\begin{array}{l}\begin{array}{l}\text { Centrifugal } \\
\text { pumps }\end{array} \\
\end{array}$ & & $\begin{array}{l}\begin{array}{l}\text { Circulate } \\
\text { coolant } \\
\text { for heat } \\
\text { transter }\end{array} \\
\end{array}$ & $\begin{array}{l}\begin{array}{l}\text { pump unit, not } \\
\text { power or } \\
\text { controls }\end{array} \\
\end{array}$ & $\begin{array}{l}\text { intermitte } \\
\text { nt }\end{array}$ & hands-on & casing rupture & $\begin{array}{l}\begin{array}{l}3 \text { E-10 per } \\
\text { hour }\end{array} \\
\end{array}$ & 30 & exponential & $\begin{array}{l}\text { casing } \\
\text { rupture }\end{array}$ & $\begin{array}{l}2.4 E-02 \\
\text { per hour }\end{array}$ & 1.5 & essimate only & casing rupture & 0.1 & & \begin{tabular}{|l} 
point \\
estimate
\end{tabular} & $\begin{array}{l}\text { casing } \\
\text { rupture }\end{array}$ & & & \\
\hline $\begin{array}{l}\text { 吕mary } \\
\text { heat } \\
\text { transter } \\
\text { systems }\end{array}$ & \begin{tabular}{|l} 
heat \\
transfer \\
loops
\end{tabular} & $\begin{array}{l}\text { Centrifiugal } \\
\text { pumps }\end{array}$ & & $\begin{array}{l}\text { Ciriculate } \\
\text { coolant } \\
\text { for heat } \\
\text { transter }\end{array}$ & $\begin{array}{l}\text { pump unit, not } \\
\text { polev ror } \\
\text { controls }\end{array}$ & $\begin{array}{l}\text { inturmitte } \\
\text { nt }\end{array}$ & hands-on & frail to start & & & & frail to start & $\begin{array}{l}8.3 E \text { E.02 } \\
\text { per hour }\end{array}$ & 12.5 & estimate only & fail to start & 0.1 & & \begin{tabular}{|l}
$\mid \begin{array}{l}\text { point } \\
\text { estimate }\end{array}$ \\
.
\end{tabular} & fail to start & $\begin{array}{l}2.5 E-02 \\
\text { per demand }\end{array}$ & & \\
\hline $\begin{array}{l}\text { 位任ary } \\
\text { trans } \\
\text { tanster } \\
\text { systems }\end{array}$ & \begin{tabular}{|l}
$\begin{array}{l}\text { heat } \\
\text { transter } \\
\text { loops }\end{array}$ \\
\end{tabular} & $\begin{array}{l}\begin{array}{l}\text { Centrifiugal } \\
\text { pumps }\end{array} \\
\end{array}$ & & \begin{tabular}{|l} 
Ciriculate \\
coolant \\
tor heat \\
transter
\end{tabular} & \begin{tabular}{|l} 
pump unit, not \\
poover or \\
controls \\
\end{tabular} & $\begin{array}{l}\text { intermitte } \\
\text { nt }\end{array}$ & hands-on & \begin{tabular}{|l} 
shat seal \\
leakage
\end{tabular} & $\mid \begin{array}{l}1 \text { E-04 per } \\
\text { year }\end{array}$ & $\begin{array}{l}\text { 位per } \\
\text { bound } \\
\text { given }\end{array}$ & \begin{tabular}{|l} 
point \\
estimate
\end{tabular} & $\begin{array}{l}\text { shat seal } \\
\text { leakage }\end{array}$ & $\begin{array}{l}2.4 E-02 \\
\text { per hour }\end{array}$ & 3.5 & estimate only & $\begin{array}{l}\text { shat seal } \\
\text { leakage }\end{array}$ & 0.1 & & \begin{tabular}{|l} 
point \\
estimate
\end{tabular} & $\begin{array}{l}\text { shat seal } \\
\text { leakage }\end{array}$ & & & \\
\hline $\begin{array}{l}\text { Primary } \\
\text { Heat } \\
\text { Transfer } \\
\text { Systems }\end{array}$ & \begin{tabular}{|l}
$\begin{array}{l}\text { heat } \\
\text { transfer } \\
\text { loops }\end{array}$ \\
\end{tabular} & pony motor & & \begin{tabular}{|l} 
lemergenc \\
y motor \\
for \\
coolant \\
pumps
\end{tabular} & $\begin{array}{l}\text { motor } \\
\text { surface, not } \\
\text { controls or } \\
\text { power }\end{array}$ & stand-by & hands-on & fail to run & $\begin{array}{l}1.66-05 \\
\text { per hour }\end{array}$ & & log normal & fail to run & $\begin{array}{l}5 \text { E-.03 per } \\
\text { hour }\end{array}$ & 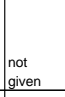 & & fail to run & 0.1 & & \begin{tabular}{|l} 
point \\
estimate
\end{tabular} & fail to run & & & \\
\hline $\begin{array}{l}\text { Primary } \\
\text { heaty } \\
\text { transter } \\
\text { systems }\end{array}$ & \begin{tabular}{|l}
$\begin{array}{l}\text { heat } \\
\text { transfer } \\
\text { loops }\end{array}$ \\
\end{tabular} & pony motor & & \begin{tabular}{|l}
$\begin{array}{l}\text { emergence } \\
\text { y motor } \\
\text { for } \\
\text { coolant } \\
\text { pumps }\end{array}$ \\
\end{tabular} & $\begin{array}{l}\text { motor } \\
\text { surface, not } \\
\text { controls ot } \\
\text { power }\end{array}$ & stand-by & hands-on & shaft break & \begin{tabular}{|l|l}
$\begin{array}{l}1 \text { E- }-08 \text { per } \\
\text { hour }\end{array}$ \\
\end{tabular} & & estimate only & shaft break & $\begin{array}{l}3 \text { E-.03 per } \\
\text { hour }\end{array}$ & $\begin{array}{l}\text { 足t } \\
\text { given }\end{array}$ & estimate only & shaft break & 0.01 & & \begin{tabular}{|l} 
point \\
estimate
\end{tabular} & shatt break & & & \\
\hline $\begin{array}{l}\text { Primary } \\
\text { heat } \\
\text { transer } \\
\text { systems }\end{array}$ & \begin{tabular}{|l} 
heat \\
transfer \\
loops
\end{tabular} & pony motor & & \begin{tabular}{|l}
$\begin{array}{l}\text { emergrenco } \\
\text { yotor } \\
\text { for } \\
\text { coolant } \\
\text { pumps }\end{array}$ \\
\end{tabular} & $\begin{array}{l}\begin{array}{l}\text { motor } \\
\text { surface, not } \\
\text { controls or } \\
\text { power }\end{array} \\
\end{array}$ & stand-by & hands-on & fail to start & & & & fail to start & $\begin{array}{l}8.3 E-02 \\
\text { per hour }\end{array}$ & 12.5 & & fail to start & 0.1 & & $\begin{array}{l}\text { Point } \\
\text { estimate }\end{array}$ & fail to start & $\begin{array}{l}\begin{array}{l}3 E-05 \text { per } \\
\text { demand }\end{array} \\
\end{array}$ & & \\
\hline
\end{tabular}


Table A-2. Heat Transfer System Data Table (continued).

\begin{tabular}{|c|c|c|c|c|c|c|c|c|c|c|c|c|c|c|c|c|c|c|c|c|c|c|c|}
\hline \multicolumn{4}{|c|}{$\begin{array}{l}\text { Component identificication according INEL } \\
\text { taxonomy }\end{array}$} & \multirow{3}{*}{ Function } & \multirow{3}{*}{\begin{tabular}{|l|} 
Component \\
boundaries \\
\end{tabular}} & \multirow{3}{*}{\begin{tabular}{|c|} 
Operatin \\
gegime \\
\end{tabular}} & \multirow{3}{*}{\begin{tabular}{|l} 
Maintenance \\
regime \\
\end{tabular}} & \multirow[b]{3}{*}{ Description } & \multirow{3}{*}{\begin{tabular}{|l|} 
Average \\
value
\end{tabular}} & \multirow{3}{*}{$\begin{array}{l}\text { Error } \\
\text { factor }\end{array}$} & \multirow{3}{*}{$\begin{array}{l}\text { Type of } \\
\text { distributiotio } \\
\text { n }\end{array}$} & \multirow[b]{3}{*}{ Description } & \multirow{3}{*}{\begin{tabular}{|l|} 
Average \\
value
\end{tabular}} & \multirow{3}{*}{\begin{tabular}{|l} 
Error \\
factor
\end{tabular}} & \multirow{3}{*}{\begin{tabular}{|l} 
Type of \\
distribution
\end{tabular}} & \multirow[b]{3}{*}{ Description } & \multirow{3}{*}{$\begin{array}{l}\text { Average } \\
\text { value }\end{array}$} & \multirow{3}{*}{\begin{tabular}{|l} 
Error \\
factor
\end{tabular}} & \multirow{3}{*}{$\begin{array}{l}\text { Type of } \\
\text { distritutito } \\
n\end{array}$} & \multirow[b]{3}{*}{ Description } & \multirow{3}{*}{\begin{tabular}{|l|} 
Average \\
value
\end{tabular}} & \multirow{3}{*}{\begin{tabular}{|l|} 
Error \\
factor
\end{tabular}} & \multirow{3}{*}{\begin{tabular}{|l} 
Trype of \\
disistribution
\end{tabular}} \\
\hline system & Subsyte & $\begin{array}{l}\text { Comp } \\
\text { Class }\end{array}$ & & & & & & & & & & & & & & & & & & & & & \\
\hline & & Lev. 1 & Lev. 2 & & & & & & & & & & & & & & & & & & & & \\
\hline \begin{tabular}{|l|} 
Primary \\
Heat \\
Transter \\
Systems \\
Poimary
\end{tabular} & $\begin{array}{l}\text { 㘳at } \\
\text { transfer } \\
\text { loops }\end{array}$ & $\begin{array}{l}\begin{array}{l}\text { neat } \\
\text { exchanger }\end{array} \\
\text { a }\end{array}$ & & $\begin{array}{l}\text { transter } \\
\text { heat rom } \\
\text { coolant }\end{array}$ & shell surface & continuous & hands-on & tube leakage & $\begin{array}{l}\text { EE-07 per } \\
\text { unith-hour }\end{array}$ & 10 & log normal & tube leakage & \begin{tabular}{|l}
$2.5 E-02$ \\
per hour
\end{tabular} & & estimate only & tube leakage & 0.01 & & $\mid$\begin{tabular}{|c} 
point \\
estimate
\end{tabular} & tube leakage & & & \\
\hline $\begin{array}{l}\text { Primary } \\
\text { heat } \\
\text { renster } \\
\text { systems }\end{array}$ & \begin{tabular}{|l} 
heat \\
transter \\
loops
\end{tabular} & $\begin{array}{l}\begin{array}{l}\text { heat } \\
\text { exchanger }\end{array} \\
\end{array}$ & & \begin{tabular}{|l} 
transter \\
heat rom \\
coolant
\end{tabular} & shell surface & continuous & hands-on & tube rupture & \begin{tabular}{|l|l}
1 1E.09 per \\
unithour
\end{tabular} & 30 & log normal & tube rupture & $\begin{array}{l}5.5 E-03 \\
\text { per hour }\end{array}$ & 4.5 & estimate only & tube rupture & 0.01 & & $\mid \begin{array}{l}\text { Point } \\
\text { estimate }\end{array}$ & tube rupture & & & \\
\hline 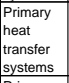 & \begin{tabular}{|l}
$\begin{array}{l}\text { heat } \\
\text { transter } \\
\text { loops }\end{array}$ \\
\end{tabular} & \begin{tabular}{|l} 
heat \\
exchanger
\end{tabular} & & $\begin{array}{l}\text { transter } \\
\text { heat rom } \\
\text { coolant }\end{array}$ & shell surface & continuous & hands-on & shell leakage & 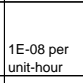 & 10 & log normal & shell leakage & $\begin{array}{l}0.07 \text { per } \\
\text { hour }\end{array}$ & 2.9 & estimate only & shell leakage & 0.01 & & \begin{tabular}{|l} 
point \\
estimate
\end{tabular} & shell leakage & & & \\
\hline $\begin{array}{l}\text { Primary } \\
\text { heat } \\
\text { ranster } \\
\text { systems }\end{array}$ & \begin{tabular}{|l} 
heat \\
transter \\
loops
\end{tabular} & $\begin{array}{l}\text { heat } \\
\text { exchanger }\end{array}$ & & $\begin{array}{l}\begin{array}{l}\text { transter } \\
\text { heat rtrom } \\
\text { coolant }\end{array} \\
\end{array}$ & shell surface & continuous & hands-on & shell rupture & \begin{tabular}{|l|l|}
1 1E-10 per \\
unit-hour
\end{tabular} & 30 & log normal & shell rupture & $\begin{array}{l}\begin{array}{l}3 \text { E-.2 per } \\
\text { hour }\end{array} \\
\text { hes }\end{array}$ & 2.6 & estimate only & shell rupture & 0.01 & & \begin{tabular}{|l} 
point \\
estimate
\end{tabular} & shell rupture & & & \\
\hline 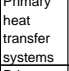 & \begin{tabular}{|l} 
heat \\
transter \\
loops
\end{tabular} & \begin{tabular}{|l} 
heat \\
exchanger
\end{tabular} & & 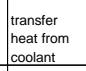 & shell surface & continuous & hands-on & tube fouling & \begin{tabular}{|l} 
1E-09 per \\
unithour
\end{tabular} & 30 & log normal & tube fouling & $\begin{array}{l}2.5 \mathrm{E}-02 \\
\text { per hour }\end{array}$ & & estimate only & tube fouling & 0.01 & & $\mid$\begin{tabular}{|c} 
point \\
estimate
\end{tabular} & tube fouling & & & \\
\hline $\begin{array}{l}\text { 位imary } \\
\text { teat } \\
\text { transter } \\
\text { systems }\end{array}$ & \begin{tabular}{|l|l} 
neat \\
transter \\
loops
\end{tabular} & $\begin{array}{l}\text { heat } \\
\text { exchanger }\end{array}$ & & $\begin{array}{l}\begin{array}{l}\text { transter } \\
\text { heat rom } \\
\text { coolant }\end{array} \\
\text { contents }\end{array}$ & shell surface & continuous & hands-on & \begin{tabular}{|l} 
degraded heat \\
transfer
\end{tabular} & $\begin{array}{l}\begin{array}{l}2 E-06 \\
\text { unithour }\end{array} \\
\text { unt }\end{array}$ & & log normal & $\begin{array}{l}\text { degraded } \\
\text { heat transter }\end{array}$ & $\begin{array}{l}1.25 E-01 \\
\text { per hour }\end{array}$ & \begin{tabular}{|l} 
upper \\
bound
\end{tabular} & $\begin{array}{l}\text { estimated } \\
\text { value }\end{array}$ & $\begin{array}{l}\begin{array}{l}\text { degraded hat } \\
\text { transfer }\end{array} \\
\text { atat }\end{array}$ & 0.01 & & \begin{tabular}{|l} 
point \\
estimate
\end{tabular} & \begin{tabular}{|l} 
degraded heat \\
transfer
\end{tabular} & & & \\
\hline \begin{tabular}{|l}
$\begin{array}{l}\text { Primary } \\
\text { heat } \\
\text { transter } \\
\text { systems }\end{array}$ \\
\end{tabular} & $\begin{array}{l}\begin{array}{l}\text { heat } \\
\text { transter } \\
\text { loops }\end{array} \\
\text { lons }\end{array}$ & $\begin{array}{l}\begin{array}{l}\text { isolation } \\
\text { value }\end{array} \\
\text { val }\end{array}$ & & $\begin{array}{l}\text { isolate } \\
\text { part of } \\
\text { flow } \\
\text { system }\end{array}$ & $\begin{array}{l}\text { surface of } \\
\text { valve, incl. } \\
\text { oporator ut } \\
\text { not controls } \\
\text { or power }\end{array}$ & $\begin{array}{l}\text { intermitite } \\
\text { ntt suse en } \\
\text { shutowns }\end{array}$ & hands-on & $\begin{array}{l}\text { tail to changes } \\
\text { position on } \\
\text { demand }\end{array}$ & & & & \begin{tabular}{|l}
$\begin{array}{l}\text { fail to } \\
\text { change } \\
\text { position on } \\
\text { demand }\end{array}$ \\
\end{tabular} & $\begin{array}{l}2 \text { E-.01 per } \\
\text { hour }\end{array}$ & & estimate only & $\begin{array}{l}\text { tail to change } \\
\text { position on } \\
\text { demand }\end{array}$ & 0.1 & & \begin{tabular}{|l} 
point \\
estimate
\end{tabular} & $\begin{array}{l}\text { tail to changene } \\
\text { position on } \\
\text { demand }\end{array}$ & \begin{tabular}{|l|}
$\begin{array}{l}7.2 E-03 \\
\text { perdemand }\end{array}$ \\
\end{tabular} & 5.3 & log normal \\
\hline $\begin{array}{l}\text { Primary } \\
\text { heat } \\
\text { transter } \\
\text { systems }\end{array}$ & $\begin{array}{l}\text { neat } \\
\text { transter } \\
\text { loops }\end{array}$ & 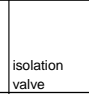 & & $\begin{array}{l}\text { isolate } \\
\text { part of } \\
\text { fliw } \\
\text { system }\end{array}$ & $\begin{array}{l}\text { surface of } \\
\text { vavevingl. } \\
\text { operator but } \\
\text { not controlls } \\
\text { or power }\end{array}$ & $\begin{array}{l}\text { intermitite } \\
\text { nt, suse in } \\
\text { shutowns }\end{array}$ & hands-on & $\begin{array}{l}\text { sporious } \\
\text { operation }\end{array} \mid$ & $\begin{array}{l}55-08 \text { per } \\
\text { hour }\end{array}$ & 10 & exponential & 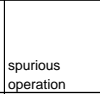 & \begin{tabular}{|l}
1.1 E- 01 \\
per hour
\end{tabular} & 3.4 & estimate only & $\begin{array}{l}\text { Spsurios } \\
\text { operation }\end{array}$ & 0.1 & & \begin{tabular}{|l} 
point \\
estimate
\end{tabular} & \begin{tabular}{|l} 
sporious \\
operation
\end{tabular} \mid & & & \\
\hline $\begin{array}{l}\text { Primary } \\
\text { heat } \\
\text { trats } \\
\text { systerems }\end{array}$ & $\begin{array}{l}\text { heat } \\
\text { transter } \\
\text { loops }\end{array}$ & $\begin{array}{l}\begin{array}{l}\text { isolation } \\
\text { value }\end{array} \\
\text { val }\end{array}$ & & $\begin{array}{l}\text { isolate } \\
\text { part of } \\
\text { flow } \\
\text { system }\end{array}$ & \begin{tabular}{|l} 
surface of \\
valve, incl. \\
operator but \\
not controls \\
or power
\end{tabular} & $\begin{array}{l}\text { nitem mitte } \\
\text { nt, suse in } \\
\text { shutdowns }\end{array}$ & hands-on & 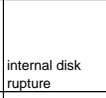 & \begin{tabular}{|l|}
1 1E.07 per \\
hour
\end{tabular} & 10 & exponential & $\begin{array}{l}\text { internal disk } \\
\text { rupture }\end{array}$ & $\begin{array}{l}3.8 \mathrm{E}-02 \\
\text { per hour }\end{array}$ & 1.3 & estimate only & $\begin{array}{l}\text { intetral lisk } \\
\text { rupture }\end{array}$ & 0.01 & & \begin{tabular}{|l} 
point \\
estimate
\end{tabular} & $\begin{array}{l}\text { internal disk } \\
\text { ruppure }\end{array}$ & & & \\
\hline \begin{tabular}{|l}
$\begin{array}{l}\text { Primary } \\
\text { heat } \\
\text { transter } \\
\text { systems }\end{array}$ \\
\end{tabular} & $\begin{array}{l}\text { heat } \\
\text { transter } \\
\text { loops }\end{array}$ & $\begin{array}{l}\begin{array}{l}\text { isolation } \\
\text { value }\end{array} \\
\text { val }\end{array}$ & & $\begin{array}{l}\text { isolate } \\
\text { part of } \\
\text { flow } \\
\text { system }\end{array}$ & $\begin{array}{l}\text { surface of } \\
\text { vave, incl. } \\
\text { opertaro but } \\
\text { not controls } \\
\text { or power }\end{array}$ & $\begin{array}{l}\text { intermitite } \\
\text { nt, suse in } \\
\text { shutoonns }\end{array}$ & hands-on & $\begin{array}{l}\text { external valve } \\
\text { body leakage }\end{array}$ & \begin{tabular}{|l|} 
EE.08 per \\
hour
\end{tabular} & 10 & exponential & $\begin{array}{l}\text { external } \\
\text { valve body } \\
\text { leakage }\end{array}$ & $\begin{array}{l}5.3 \mathrm{E}-02 \\
\text { per hour }\end{array}$ & $1.5 \mathrm{~S}$ & estimate only & \begin{tabular}{|} 
external valve \\
body leakagege
\end{tabular} & 0.01 & & \begin{tabular}{|l} 
point \\
estimate
\end{tabular} & $\begin{array}{l}\text { external } \\
\text { value body } \\
\text { leakage }\end{array}$ & & & \\
\hline \begin{tabular}{|l} 
Primary \\
heat \\
transter \\
systems
\end{tabular} & $\begin{array}{l}\text { heat } \\
\text { transter } \\
\text { loops }\end{array}$ & $\begin{array}{l}\begin{array}{l}\text { isolation } \\
\text { value }\end{array} \\
\text { int }\end{array}$ & & $\begin{array}{l}\text { isolate } \\
\text { part of } \\
\text { flow } \\
\text { system }\end{array}$ & $\begin{array}{l}\text { surface of } \\
\text { vave, incl. } \\
\text { ooperator but } \\
\text { not ontrols } \\
\text { or powerer }\end{array}$ & $\begin{array}{l}\text { intermitte } \\
\text { nt, suse in } \\
\text { shutoonns }\end{array}$ & hands-on & $\begin{array}{l}\text { external valve } \\
\text { body rupture }\end{array}$ & \begin{tabular}{|l}
1 1E-10 per \\
hour
\end{tabular} & 30 & exponential & $\begin{array}{l}\text { external } \\
\text { value body } \\
\text { rupture }\end{array}$ & \begin{tabular}{|l}
$1.96-02$ \\
per hour
\end{tabular} & $\begin{array}{l}\text { 背per } \\
\text { bound } \\
\text { value }\end{array}$ & estimate only & \begin{tabular}{|l} 
external valuve \\
body rupture
\end{tabular} & 0.01 & & \begin{tabular}{|l} 
point \\
estimate
\end{tabular} & $\begin{array}{l}\text { external } \\
\text { valave body } \\
\text { rupture }\end{array}$ & & & \\
\hline $\begin{array}{l}\text { Primary } \\
\text { heat } \\
\text { trats } \\
\text { systerems } \\
\text { ser }\end{array}$ & $\begin{array}{l}\text { heat } \\
\text { transfer } \\
\text { loops }\end{array}$ & $\begin{array}{l}\begin{array}{l}\text { isolation } \\
\text { value }\end{array} \\
\text { ant }\end{array}$ & & $\begin{array}{l}\begin{array}{l}\text { isolate } \\
\text { 价 of } \\
\text { fitow } \\
\text { system }\end{array} \\
\end{array}$ & $\begin{array}{l}\text { surface of } \\
\text { value, incl } \\
\text { oporataror but } \\
\text { not ontrols } \\
\text { or power }\end{array}$ & $\begin{array}{l}\text { intermite } \\
\text { nt, use in } \\
\text { shutdowns }\end{array}$ & hands-on & \begin{tabular}{|l} 
valve intermal \\
disk leakkage
\end{tabular} & $\begin{array}{l}\text { EE-06 per } \\
\text { hour }\end{array}$ & & exponential & \begin{tabular}{|l} 
valve \\
internal disk \\
leakage
\end{tabular} & \begin{tabular}{|l}
$4.4 E-02$ \\
per hour
\end{tabular} & & estimate only & 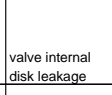 & 0.01 & & \begin{tabular}{|} 
point \\
estimate
\end{tabular} & $\begin{array}{l}\text { valve intermal } \\
\text { disk leakageg }\end{array}$ & & & \\
\hline
\end{tabular}


Table A-2. Heat Transfer System Data Table (continued).

\begin{tabular}{|c|c|c|c|c|c|c|c|c|c|c|c|c|c|c|c|c|c|c|c|c|c|c|c|}
\hline \multicolumn{4}{|c|}{\begin{tabular}{|c|}
$\begin{array}{c}\text { Component identification according INEL } \\
\text { taxonomy }\end{array}$ \\
\end{tabular}} & \multirow{3}{*}{ Function } & \multirow{3}{*}{\begin{tabular}{|l} 
Component \\
boundaries \\
\end{tabular}} & \multirow{3}{*}{\begin{tabular}{|c|c} 
Operatin \\
regime \\
\end{tabular}} & \multirow{3}{*}{$\begin{array}{l}\text { Maintenance } \\
\text { regime }\end{array}$} & \multirow[b]{3}{*}{ Description } & \multirow{3}{*}{\begin{tabular}{|l} 
Average \\
value \\
\end{tabular}} & \multirow{3}{*}{\begin{tabular}{|l} 
Error \\
factor
\end{tabular}} & \multirow{3}{*}{\begin{tabular}{|l}
$\begin{array}{r}\text { Type of } \\
\text { distributio } \\
n\end{array}$ \\
\end{tabular}} & \multirow[b]{3}{*}{ Description } & \multirow{3}{*}{\begin{tabular}{|l} 
Average \\
value
\end{tabular}} & \multirow{3}{*}{$\begin{array}{l}\text { Error } \\
\text { factor }\end{array}$} & \multirow{3}{*}{\begin{tabular}{|l|} 
Type of \\
distribution \\
\end{tabular}} & \multirow[b]{3}{*}{ Description } & \multirow{3}{*}{\begin{tabular}{|l} 
Average \\
value
\end{tabular}} & \multirow{3}{*}{\begin{tabular}{|l|} 
Error \\
factor
\end{tabular}} & \multirow{3}{*}{\begin{tabular}{|l} 
Type of \\
distrtibutio \\
nit
\end{tabular}} & \multirow[b]{3}{*}{ Description } & \multirow{3}{*}{\begin{tabular}{|l} 
Average \\
value
\end{tabular}} & \multirow{3}{*}{\begin{tabular}{|l} 
Error \\
factor \\
\end{tabular}} & \multirow{3}{*}{\begin{tabular}{|l} 
Type of \\
disistribution
\end{tabular}} \\
\hline \multirow{2}{*}{ System } & Subsytem & \multicolumn{2}{|c|}{$\begin{array}{l}\text { Component Sub } \\
\text { Classititaction }\end{array}$} & & & & & & & & & & & & & & & & & & & & \\
\hline & sousyem & Lev. 1 & Lev. 2 & & & & & & & & & & & & & & & & & & & & \\
\hline $\begin{array}{l}\text { 侻位ary } \\
\text { transter } \\
\text { systems }\end{array}$ & \begin{tabular}{|l}
$\begin{array}{l}\text { heat } \\
\text { transfer } \\
\text { loops }\end{array}$ \\
\end{tabular} & pressurizer & & \begin{tabular}{|l} 
maderate \\
any \\
pressure \\
changes
\end{tabular} & tank surface & $\begin{array}{l}\text { conninuous } \\
\text { while ITER } \\
\text { operates }\end{array}$ & hands-on & $\begin{array}{l}\text { external } \\
\text { leakage }\end{array}$ & \begin{tabular}{|l} 
EE.08 per \\
hour
\end{tabular} & 10 & exponential & $\begin{array}{l}\text { external } \\
\text { leakage }\end{array}$ & $\begin{array}{l}1.6 \mathrm{E}-01 \\
\text { per hour }\end{array}$ & \begin{tabular}{|}
$\mid \begin{array}{l}\text { poper } \\
\text { bound } \\
\text { value }\end{array}$ \\
vel
\end{tabular} & estimate only & $\begin{array}{l}\text { external } \\
\text { leakage }\end{array}$ & 0.01 & & \begin{tabular}{|l} 
point \\
estimate
\end{tabular} & \begin{tabular}{|l} 
extermal \\
leakage
\end{tabular} & & & \\
\hline $\begin{array}{l}\text { 位任ary } \\
\text { transter } \\
\text { systems }\end{array}$ & $\begin{array}{l}\text { neat } \\
\text { transter } \\
\text { loops }\end{array}$ & pressurizer & & \begin{tabular}{|l} 
moderate \\
any \\
pressure \\
changes
\end{tabular} & tank surface & $\begin{array}{l}\text { conninuous } \\
\text { while ITER } \\
\text { operates }\end{array}$ & hands-on & $\begin{array}{l}\begin{array}{l}\text { external } \\
\text { rupture }\end{array} \\
\end{array}$ & $\begin{array}{l}\text { EE-10 per } \\
\text { hour }\end{array}$ & 30 & exponential & 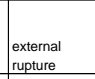 & $\begin{array}{l}3.8 \mathrm{E}-02 \\
\text { per hour }\end{array}$ & & estimate only & $\begin{array}{l}\text { extemal } \\
\text { rupture }\end{array}$ & 0.01 & & \begin{tabular}{|l} 
point \\
estimate
\end{tabular} & $\begin{array}{l}\begin{array}{l}\text { extemal } \\
\text { rupure }\end{array} \\
\text { nate }\end{array}$ & & & \\
\hline $\begin{array}{l}\text { 吕mary } \\
\text { heat } \\
\text { transter } \\
\text { systems }\end{array}$ & \begin{tabular}{|l} 
heat \\
transfer \\
loops
\end{tabular} & pressurizer & & $\begin{array}{l}\text { moderate } \\
\text { any } \\
\text { pressure } \\
\text { changes }\end{array}$ & tank surface & $\begin{array}{l}\text { continuous } \\
\text { while IIER } \\
\text { operates }\end{array}$ & hands-on & filow blockage & $\begin{array}{l}1 \text { E-10 per } \\
\text { hour }\end{array}$ & 30 & exponential & $\begin{array}{l}\text { lltw } \\
\text { blockage }\end{array}$ & $\begin{array}{l}0.5 \text { per } \\
\text { hour }\end{array}$ & & B estimate only & flow blockage & 0.1 & & $\mid \begin{array}{l}\text { point } \\
\text { estimate }\end{array}$ & flow blockage & & & \\
\hline $\begin{array}{l}\begin{array}{l}\text { Primary } \\
\text { heat } \\
\text { transter } \\
\text { systems }\end{array}\end{array}$ & \begin{tabular}{|l} 
heat \\
transter \\
loops
\end{tabular} & pressurizer & 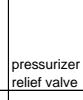 & $\begin{array}{l}\text { vent } \\
\text { overpess } \\
\text { urue in } \\
\text { colont } \\
\text { system } \\
\text { system }\end{array}$ & $\begin{array}{l}\text { valuve body,y } \\
\text { not controls } \\
\text { or signals }\end{array}$ & $\begin{array}{l}\text { conninuous } \\
\text { while ITER } \\
\text { operates }\end{array}$ & hands-on & $\begin{array}{l}\text { failt open on } \\
\text { demand }\end{array}$ & & & & $\begin{array}{l}\text { fail to open } \\
\text { on demand }\end{array}$ & $\begin{array}{l}5 E-02 \text { per } \\
\text { hour }\end{array}$ & 12.25 & estimate only & $\begin{array}{l}\text { fail to open on } \\
\text { demand }\end{array}$ & 0.1 & & \begin{tabular}{|l} 
point \\
estimate
\end{tabular} & $\begin{array}{l}\text { fail to open } \\
\text { on demand }\end{array}$ & $\begin{array}{l}4 \text { EE-03 per } \\
\text { demand }\end{array}$ & & $3 \log$ normal \\
\hline $\begin{array}{l}\text { Primary } \\
\text { Pheat } \\
\text { transter } \\
\text { system S }\end{array}$ & $\begin{array}{l}\text { heat } \\
\text { transter } \\
\text { loops }\end{array}$ & pressurizer & 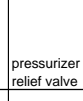 & $\begin{array}{l}\text { vent } \\
\text { overpess } \\
\text { urue in } \\
\text { cololant } \\
\text { system } \\
\end{array}$ & \begin{tabular}{|l} 
valve body, \\
notot ontrols \\
or signals
\end{tabular} & \begin{tabular}{|l} 
continuous \\
while ITER \\
operates
\end{tabular} & hands-on & $\begin{array}{l}\text { failt oclose on } \\
\text { demand }\end{array}$ & & & & $\begin{array}{l}\text { fail to close } \\
\text { on demand }\end{array}$ & $\begin{array}{l}5 E-02 \text { per } \\
\text { hour }\end{array}$ & 12.25 & estimate only & $\begin{array}{l}\text { fail to close } \\
\text { on demand }\end{array}$ & 0.1 & & \begin{tabular}{|l} 
point \\
estimate
\end{tabular} & $\begin{array}{l}\text { fail to cosese } \\
\text { on demand }\end{array}$ & 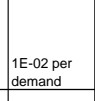 & & $3 \log$ normal \\
\hline $\begin{array}{l}\text { Primary } \\
\text { heat } \\
\text { transter } \\
\text { systems }\end{array}$ & \begin{tabular}{|l} 
heat \\
transter \\
loops
\end{tabular} & pressurizer & $\begin{array}{l}\text { pressurizer } \\
\text { reliet value }\end{array}$ & $\begin{array}{l}\text { vent } \\
\text { overess } \\
\text { urue in } \\
\text { colant } \\
\text { system } \\
\text { system }\end{array}$ & $\begin{array}{l}\text { value body, } \\
\text { not controls } \\
\text { or signals }\end{array}$ & $\begin{array}{l}\text { conntinuous } \\
\text { while ITER } \\
\text { operate }\end{array}$ & hands-on & $\begin{array}{l}\text { spurious } \\
\text { operation }\end{array}$ & $\begin{array}{l}1.5 E-07 \\
\text { per hour }\end{array}$ & 10 & exponential & $\begin{array}{l}\text { spurious } \\
\text { operation }\end{array}$ & \begin{tabular}{|l}
$1.11-01$ \\
per hour
\end{tabular} & 3.4 & 4 estimate only & \begin{tabular}{|l} 
spurious \\
operation
\end{tabular} & 0.1 & & \begin{tabular}{|l} 
point \\
estimate
\end{tabular} & \begin{tabular}{|l} 
spurious \\
operation
\end{tabular} & & & \\
\hline $\begin{array}{l}\begin{array}{l}\text { Primary } \\
\text { heat } \\
\text { transter } \\
\text { system }\end{array} \\
\end{array}$ & \begin{tabular}{|l} 
heat \\
transter \\
loops
\end{tabular} & pressurizer & $\begin{array}{l}\substack{\text { pressurizer } \\
\text { relief value }} \\
\text { nat }\end{array}$ & $\begin{array}{l}\text { vent } \\
\text { overpess } \\
\text { urue in } \\
\text { colonant } \\
\text { system }\end{array}$ & $\begin{array}{l}\text { valve body, } \\
\text { not controls } \\
\text { or signals }\end{array}$ & $\begin{array}{l}\text { cocontinuous } \\
\text { while ITER } \\
\text { operates }\end{array}$ & hands-on & $\begin{array}{l}\text { internal disk } \\
\text { rupture }\end{array}$ & $\begin{array}{l}3 \text { BE-07 per } \\
\text { hour }\end{array}$ & 10 & exponential & $\begin{array}{l}\text { internal disk } \\
\text { rupture }\end{array}$ & $\begin{array}{l}3.8 E-02 \\
\text { per hour }\end{array}$ & 1.8 & estimate only & $\begin{array}{l}\text { intermal disk } \\
\text { rupture }\end{array}$ & 0.01 & & \begin{tabular}{|l} 
point \\
estimate
\end{tabular} & $\begin{array}{l}\substack{\text { internal disk } \\
\text { rupture }} \\
\end{array}$ & & & \\
\hline $\begin{array}{l}\text { Primary } \\
\text { heat } \\
\text { transter } \\
\text { systeems }\end{array}$ & $\begin{array}{l}\text { neat } \\
\text { transter } \\
\text { loops }\end{array}$ & pressurizer & 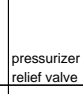 & $\begin{array}{l}\text { vent } \\
\text { overpess } \\
\text { ure in } \\
\text { cololant } \\
\text { system } \\
\end{array}$ & $\begin{array}{l}\text { valve body, } \\
\text { not controls } \\
\text { or signals }\end{array}$ & $\begin{array}{l}\text { conninuous } \\
\text { while ITER } \\
\text { operates }\end{array}$ & hands-on & \begin{tabular}{|l} 
extermal valve \\
booyy leakage
\end{tabular} & $\begin{array}{l}3 \text { BE-08 per } \\
\text { hour }\end{array}$ & & exponential & \begin{tabular}{|l} 
external \\
value body \\
leakage
\end{tabular} & $\begin{array}{l}5.3 \mathrm{E}-02 \\
\text { per hour }\end{array}$ & 1.5 & 5 estimate only & $\begin{array}{l}\text { external valve } \\
\text { body leakage }\end{array}$ & 0.01 & & \begin{tabular}{|l} 
point \\
estimate
\end{tabular} & $\begin{array}{l}\text { external } \\
\text { valve body } \\
\text { leakage }\end{array}$ & & & \\
\hline $\begin{array}{l}\text { Primary } \\
\text { heat } \\
\text { transer } \\
\text { systems }\end{array}$ & $\begin{array}{l}\text { heat } \\
\text { transfer } \\
\text { loops }\end{array}$ & pressurizer & $\begin{array}{l}\text { pressurizer } \\
\text { reliet value }\end{array}$ & $\begin{array}{l}\text { vent } \\
\text { overpess } \\
\text { urue in } \\
\text { colont } \\
\text { system }\end{array}$ & \begin{tabular}{|l} 
value body, \\
not controls \\
or signals
\end{tabular} & $\begin{array}{l}\text { continuous } \\
\text { while ITER } \\
\text { operates }\end{array}$ & hands-on & $\begin{array}{l}\begin{array}{l}\text { external valve } \\
\text { body rupture }\end{array} \\
\end{array}$ & $\begin{array}{l}3 \text { E-10 per } \\
\text { hour }\end{array}$ & 30 & exponential & $\begin{array}{l}\text { external } \\
\text { valve body } \\
\text { rupture }\end{array}$ & $\begin{array}{l}1.96-\text { - our } \\
\text { per hour }\end{array}$ & \begin{tabular}{|} 
upper \\
bound \\
value
\end{tabular} & estimate only & 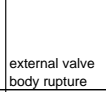 & 0.01 & & $\mid \begin{array}{l}\text { point } \\
\text { estimate }\end{array}$ & $\begin{array}{l}\text { external } \\
\text { valve body } \\
\text { rupture }\end{array}$ & & & \\
\hline $\begin{array}{l}\text { Primary } \\
\text { neat } \\
\text { transer } \\
\text { systems }\end{array}$ & $\begin{array}{l}\text { heat } \\
\text { transter } \\
\text { loops }\end{array}$ & pressurizer & $\begin{array}{l}\text { pressurizer } \\
\text { relief value }\end{array}$ & $\begin{array}{l}\text { vent } \\
\text { overpess } \\
\text { aurin } \\
\text { coolant } \\
\text { system } \\
\text { syste }\end{array}$ & $\begin{array}{l}\text { value bodyly } \\
\text { not controls } \\
\text { or signals }\end{array}$ & $\begin{array}{l}\text { continuous } \\
\text { while ITER } \\
\text { operates }\end{array}$ & hands-on & \begin{tabular}{|l} 
valve internal \\
disk leakage
\end{tabular} & $\begin{array}{l}\begin{array}{l}3 E-06 \text { per } \\
\text { hour }\end{array} \\
\text { hen }\end{array}$ & & exponential & \begin{tabular}{|l} 
valve \\
internal disk \\
leakage
\end{tabular} & $\begin{array}{l}4.4 E-02 \\
\text { per hour }\end{array}$ & 1. & 1) estimate only & \begin{tabular}{|l} 
valve internal \\
disk leakage
\end{tabular} & 0.01 & & \begin{tabular}{|l} 
point \\
estimate
\end{tabular} & \begin{tabular}{|l}
$\begin{array}{l}\text { valve internal } \\
\text { disk leakage }\end{array}$ \\
\end{tabular} & & & \\
\hline 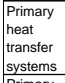 & \begin{tabular}{|l} 
heat \\
transter \\
loops
\end{tabular} & pressurizer & block valve & \begin{tabular}{|l} 
isolate \\
relief \\
value
\end{tabular} & $\begin{array}{l}\text { value surface, } \\
\text { opoer ator but } \\
\text { not pouer or } \\
\text { controls }\end{array}$ & standby & hands-on & $\begin{array}{l}\begin{array}{l}\text { fail to change } \\
\text { position on } \\
\text { demand }\end{array} \\
\end{array}$ & & & & \begin{tabular}{|l} 
frilt to \\
change \\
posstition on \\
demand
\end{tabular} & $\begin{array}{l}2 E-01 \text { per } \\
\text { hour }\end{array}$ & & estimate only & $\begin{array}{l}\begin{array}{l}\text { tailt o change } \\
\text { postitio on } \\
\text { demand }\end{array} \\
\end{array}$ & 0.1 & & \begin{tabular}{|l} 
point \\
estimate
\end{tabular} & $\begin{array}{l}\begin{array}{l}\text { tail to change } \\
\text { position on } \\
\text { demand }\end{array} \\
\end{array}$ & $\begin{array}{l}3.6 E-02 \\
\text { per demand }\end{array}$ & & $4 \log$ normal \\
\hline 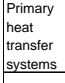 & $\begin{array}{l}\text { heat } \\
\text { transfer } \\
\text { loops }\end{array}$ & pressurizer & block valve & $\begin{array}{l}\text { isolate } \\
\text { 吕ief } \\
\text { value }\end{array}$ & $\begin{array}{l}\text { valve surface, } \\
\text { operator but } \\
\text { not powerov or } \\
\text { controls }\end{array}$ & standby & hands-on & \begin{tabular}{|l} 
spurious \\
operation
\end{tabular} & $\begin{array}{l}5 E-08 \text { per } \\
\text { hour }\end{array}$ & & exponential & $\begin{array}{l}\text { spurious } \\
\text { operation }\end{array}$ & $\begin{array}{l}1.11-01 \\
\text { per hour } \\
\end{array}$ & 3 & 4 estimate only & $\begin{array}{l}\text { spurious } \\
\text { operation }\end{array}$ & 0.1 & & \begin{tabular}{|l} 
point \\
estimate
\end{tabular} & \begin{tabular}{|l} 
spurious \\
operation
\end{tabular} & & & \\
\hline
\end{tabular}


Table A-2. Heat Transfer System Data Table (continued).

\begin{tabular}{|c|c|c|c|c|c|c|c|c|c|c|c|c|c|c|c|c|c|c|c|c|c|c|c|}
\hline \multicolumn{4}{|c|}{\begin{tabular}{|l|} 
Component identification according INEL \\
taxonomy
\end{tabular}} & \multirow{3}{*}{ Function } & \multirow{3}{*}{\begin{tabular}{|l|} 
Component \\
boundaries
\end{tabular}} & \multirow{3}{*}{\begin{tabular}{|c|} 
Operatin \\
gime \\
regime
\end{tabular}} & \multirow{3}{*}{\begin{tabular}{|l|} 
Maintenance \\
regime
\end{tabular}} & \multirow[b]{3}{*}{ Description } & \multirow{3}{*}{\begin{tabular}{|l} 
Average \\
value \\
\end{tabular}} & \multirow{3}{*}{\begin{tabular}{|l} 
Error \\
factor \\
\end{tabular}} & \multirow{3}{*}{\begin{tabular}{|l} 
Type of \\
distritiutio \\
$n$
\end{tabular}} & \multirow[b]{3}{*}{ Description } & \multirow{3}{*}{\begin{tabular}{|l} 
Average \\
value
\end{tabular}} & \multirow{3}{*}{$\begin{array}{l}\text { Error } \\
\text { factor }\end{array}$} & \multirow{3}{*}{\begin{tabular}{|l} 
Type of \\
distribution \\
\end{tabular}} & \multirow[b]{3}{*}{ Description } & \multirow{3}{*}{\begin{tabular}{|l} 
Average \\
value
\end{tabular}} & \multirow{3}{*}{\begin{tabular}{|l} 
Error \\
factor
\end{tabular}} & \multirow{3}{*}{$\begin{array}{c}\text { Type of } \\
\text { distritubutio } \\
n\end{array}$} & \multirow[b]{3}{*}{ Description } & \multirow{3}{*}{\begin{tabular}{|l|} 
Average \\
value
\end{tabular}} & \multirow{3}{*}{\begin{tabular}{|l|} 
Error \\
factor \\
\end{tabular}} & \multirow{3}{*}{\begin{tabular}{|l} 
Type of \\
disistribution
\end{tabular}} \\
\hline System & Subsytem & $\begin{array}{l}\text { Compon } \\
\text { Classifi }\end{array}$ & $\begin{array}{l}\text { ent Sub } \\
\text { ation }\end{array}$ & & & & & & & & & & & & & & & & & & & & \\
\hline & & Lev. 1 & Lev. 2 & & & & & & & & & & & & & & & & & & & & \\
\hline \begin{tabular}{|l|} 
nerimaty \\
traat \\
syster \\
systems
\end{tabular} & $\begin{array}{l}\text { heat } \\
\text { transfer } \\
\text { loops }\end{array}$ & pressurizer & block valve & $\begin{array}{l}\text { isolate } \\
\text { relief } \\
\text { value }\end{array}$ & $\begin{array}{l}\text { valve surface, } \\
\text { operator but } \\
\text { not power or } \\
\text { controls }\end{array}$ & standby & hands-on & $\begin{array}{l}\text { internal disk } \\
\text { ruppture }\end{array}$ & \begin{tabular}{|l}
1 E- -07 per \\
hour
\end{tabular} & & exponential & $\begin{array}{l}\text { internal disk } \\
\text { rupture }\end{array}$ & \begin{tabular}{|l}
$3.8 E-02$ \\
per hour
\end{tabular} & 1. & estimate only & $\begin{array}{l}\text { internal idsk } \\
\text { rupture }\end{array}$ & 0.01 & & \begin{tabular}{|l} 
point \\
estimate
\end{tabular} & $\begin{array}{l}\text { internal disk } \\
\text { ruppure }\end{array}$ & & & \\
\hline \begin{tabular}{|} 
Primary \\
nean \\
stanster \\
systems
\end{tabular} & \begin{tabular}{|l|}
$\begin{array}{l}\text { heat } \\
\text { transter } \\
\text { loops }\end{array}$ \\
\end{tabular} & pressurizer & block valve & \begin{tabular}{|l}
$\begin{array}{l}\text { isolate } \\
\text { reief } \\
\text { value }\end{array}$ \\
\end{tabular} & $\begin{array}{l}\text { valve surface, } \\
\text { operator but } \\
\text { not power or } \\
\text { controls }\end{array}$ & standby & hands-on & $\begin{array}{l}\begin{array}{l}\text { extemal valve } \\
\text { body leakage }\end{array} \\
\end{array}$ & \begin{tabular}{|l} 
EE-08 per \\
hour
\end{tabular} & & exponential & $\begin{array}{l}\text { external } \\
\text { valve body } \\
\text { leakage }\end{array}$ & $\begin{array}{l}5.3 E-02 \\
\text { per hour }\end{array}$ & 1. & estimate only & \begin{tabular}{|l} 
external valve \\
body leakage
\end{tabular} & 0.01 & & \begin{tabular}{|l} 
point \\
estimate
\end{tabular} & $\begin{array}{l}\text { external } \\
\text { valave body } \\
\text { leakage }\end{array}$ & & & \\
\hline $\begin{array}{l}\text { 位位ary } \\
\text { transter } \\
\text { systems }\end{array}$ & $\begin{array}{l}\text { heat } \\
\text { transter } \\
\text { loops }\end{array}$ & pressurizer & block valve & $\begin{array}{l}\text { isolate } \\
\text { 位ef } \\
\text { value }\end{array}$ & 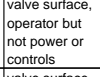 & standby & hands-on & $\begin{array}{l}\begin{array}{l}\text { extemal valve } \\
\text { body rupture }\end{array} \\
\end{array}$ & \begin{tabular}{|l} 
EE-10 per \\
hour
\end{tabular} & & exponential & $\begin{array}{l}\text { external } \\
\text { valve body } \\
\text { rupure }\end{array}$ & $\begin{array}{l}1.9 E-02 \\
\text { per hour }\end{array}$ & $\begin{array}{l}\text { upper } \\
\text { bound } \\
\text { value }\end{array}$ & estimate only & \begin{tabular}{|l} 
external valve \\
body uputure
\end{tabular} & 0.01 & & $\mid$\begin{tabular}{|l} 
posint \\
estimate
\end{tabular} & $\begin{array}{l}\text { external } \\
\text { value body } \\
\text { rupture }\end{array}$ & & & \\
\hline \begin{tabular}{|l} 
rimimaty \\
transter \\
systems
\end{tabular} & $\begin{array}{l}\text { heat } \\
\text { transter } \\
\text { loops }\end{array}$ & pressurizer & block valve & $\begin{array}{l}\text { isclate } \\
\text { 隹ief } \\
\text { value }\end{array}$ & $\begin{array}{l}\text { vave surface, } \\
\text { oper ato but } \\
\text { not power or } \\
\text { controls }\end{array}$ & standby & hands-on & $\begin{array}{l}\text { value internal } \\
\text { disk leakage }\end{array}$ & $\begin{array}{l}\mid \begin{array}{l}\text { E- }-06 \text { per } \\
\text { hour }\end{array} \\
\text { hen }\end{array}$ & & exponential & 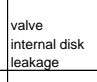 & \begin{tabular}{|l}
$4.4 E-02$ \\
per hour
\end{tabular} & 1. & estimate only & \begin{tabular}{|l} 
valve intermal \\
disk leakage
\end{tabular} & 0.01 & & \begin{tabular}{|l} 
point \\
estimate
\end{tabular} & \begin{tabular}{|l} 
valve intermal \\
disk leakage
\end{tabular} & & & \\
\hline \begin{tabular}{|l|} 
Primaty \\
reat \\
sanster \\
systems
\end{tabular} & $\begin{array}{l}\text { leat } \\
\text { transter } \\
\text { loops }\end{array}$ & $\begin{array}{l}\text { instrumentati } \\
\text { on }\end{array}$ & $\begin{array}{l}\text { temperature } \\
\text { instrument }\end{array}$ & $\begin{array}{l}\text { read fluid } \\
\text { temperatu } \\
\text { re }\end{array}$ & $\begin{array}{l}\text { instrument } \\
\text { but not power } \\
\text { or signals }\end{array}$ & continuous & hands-on & $\begin{array}{l}\text { fail of tunction } \\
\text { on demand }\end{array}$ & & & & $\begin{array}{l}\text { tail to } \\
\text { tunction on } \\
\text { demand }\end{array}$ & \begin{tabular}{|l}
$\begin{array}{l}3.3 E E-01 \\
\text { per hour }\end{array}$ \\
\end{tabular} & $\begin{array}{l}\text { not } \\
\text { given }\end{array}$ & $\begin{array}{l}\text { point } \\
\text { estimate }\end{array}$ & \begin{tabular}{|l} 
fail to \\
tunction on \\
demand
\end{tabular} & 0.1 & & \begin{tabular}{|l} 
point \\
estimate
\end{tabular} & $\begin{array}{l}\text { fail to } \\
\text { tunction on } \\
\text { demand }\end{array}$ & $\begin{array}{l}1.95-03 \\
\text { per demand }\end{array}$ & & $8 \log$ normal \\
\hline \begin{tabular}{|} 
Primary \\
neat \\
stanster \\
systems \\
sotem
\end{tabular} & \begin{tabular}{|l|l}
$\begin{array}{l}\text { neat } \\
\text { transter } \\
\text { loops }\end{array}$ \\
\end{tabular} & $\begin{array}{l}\text { instrumentati } \\
\text { on }\end{array}$ & $\begin{array}{l}\text { temperature } \\
\text { instrument }\end{array}$ & $\begin{array}{l}\text { read fluid } \\
\text { temperatu } \\
\text { re }\end{array}$ & \begin{tabular}{|l} 
instrument \\
but not power \\
or signals
\end{tabular} & continuous & hands-on & $\begin{array}{l}\text { spurious } \\
\text { operation }\end{array}$ & $\begin{array}{l}\begin{array}{l}\text { EE-07 per } \\
\text { hour }\end{array} \\
\text { hen }\end{array}$ & 2.6 & log normal & $\begin{array}{l}\text { spurious } \\
\text { operation }\end{array}$ & $\begin{array}{l}3.3 \mathrm{E}-01 \\
\text { per hour }\end{array}$ & $\begin{array}{l}\text { not } \\
\text { given }\end{array}$ & $\begin{array}{l}\text { point } \\
\text { estimate }\end{array}$ & \begin{tabular}{|l} 
spurious \\
operation
\end{tabular} & 0.1 & & \begin{tabular}{|l} 
point \\
estimate
\end{tabular} & \begin{tabular}{|l} 
spurious \\
operation
\end{tabular} & & & \\
\hline \begin{tabular}{|l|} 
Primary \\
neat \\
transter \\
systems
\end{tabular} & $\begin{array}{l}\begin{array}{l}\text { heat } \\
\text { transter } \\
\text { loops }\end{array} \\
\text { lons }\end{array}$ & $\begin{array}{l}\text { instrumentati } \\
\text { on }\end{array}$ & \begin{tabular}{|l} 
pressure \\
instrument
\end{tabular} & $\begin{array}{l}\text { read fluid } \\
\text { pressure }\end{array}$ & $\begin{array}{l}\text { instrument } \\
\text { but tot power } \\
\text { or signals }\end{array}$ & continuous & hands-on & $\begin{array}{l}\text { fail of tunction } \\
\text { on demand }\end{array}$ & & & & $\begin{array}{l}\text { tail to } \\
\text { tunction on } \\
\text { demand }\end{array}$ & $\begin{array}{l}0.5 \text { per } \\
\text { hour }\end{array}$ & $\begin{array}{l}\text { not } \\
\text { given }\end{array}$ & $\begin{array}{l}\text { point } \\
\text { estimate }\end{array}$ & \begin{tabular}{|l} 
fail to \\
truntion on \\
demand
\end{tabular} & 0.1 & & \begin{tabular}{|l} 
point \\
estimate
\end{tabular} & \begin{tabular}{|l} 
fail to \\
function on \\
demand
\end{tabular} & $\begin{array}{l}\text { 7F-04 per } \\
\text { demand }\end{array}$ & & 4 |log normal \\
\hline $\begin{array}{l}\text { 位位ary } \\
\text { transter } \\
\text { systems }\end{array}$ & $\begin{array}{l}\text { 省ean } \\
\text { transter } \\
\text { loops }\end{array}$ & $\begin{array}{l}\text { instrumentati } \\
\text { on }\end{array}$ & \begin{tabular}{|l}
$\begin{array}{l}\text { pressure } \\
\text { instrument }\end{array}$ \\
\end{tabular} & $\begin{array}{l}\text { read fluid } \\
\text { pressure }\end{array}$ & \begin{tabular}{|l} 
instrument \\
but not power \\
or signals
\end{tabular} & continuous & hands-on & $\begin{array}{l}\text { spurious } \\
\text { operation }\end{array}$ & \begin{tabular}{|l}
$8.75-07$ \\
per hour
\end{tabular} & 2.5 & log normal & $\begin{array}{l}\text { spurious } \\
\text { operation }\end{array}$ & $\begin{array}{l}0.5 \text { per } \\
\text { hour }\end{array}$ & $\begin{array}{l}\text { not } \\
\text { given }\end{array}$ & $\begin{array}{l}\text { point } \\
\text { estimate }\end{array}$ & $\begin{array}{l}\text { spurious } \\
\text { operation }\end{array}$ & 0.1 & & \begin{tabular}{|l} 
point \\
estimate
\end{tabular} & $\begin{array}{l}\text { spurious } \\
\text { operation } \\
\end{array}$ & & & \\
\hline $\begin{array}{l}\text { 位位ary } \\
\text { transter } \\
\text { systems }\end{array}$ & 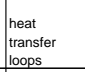 & $\begin{array}{l}\text { instrumentati } \\
\text { on }\end{array}$ & $\begin{array}{l}\text { ffow } \\
\text { linstrument }\end{array}$ & $\begin{array}{l}\begin{array}{l}\text { read fluid } \\
\text { flow } \\
\text { speed }\end{array} \\
\end{array}$ & \begin{tabular}{|l} 
instrument \\
but not power \\
or signals
\end{tabular} & continuous & hands:on & $\begin{array}{l}\text { tail to funtion } \\
\text { on demand }\end{array}$ & & & & $\begin{array}{l}\text { fail to } \\
\text { function on } \\
\text { demand }\end{array}$ & $\begin{array}{l}{\left[\begin{array}{l}0.5 \mathrm{ser} \\
\text { hour }\end{array}\right.} \\
\text {. }\end{array}$ & $\mid \begin{array}{l}\text { not } \\
\text { given }\end{array}$ & $\begin{array}{l}\text { Point } \\
\text { estimate }\end{array}$ & $\begin{array}{l}\text { tail to } \\
\text { function on } \\
\text { demand }\end{array}$ & 0.1 & & $\mid \begin{array}{l}\text { point } \\
\text { estimate }\end{array}$ & $\begin{array}{l}\text { fail to } \\
\text { tunction on } \\
\text { demand }\end{array}$ & $\begin{array}{l}3.3 E-03 \\
\text { per demand }\end{array}$ & & 3 log normal \\
\hline 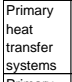 & \begin{tabular}{|l}
$\begin{array}{l}\text { neat } \\
\text { transter } \\
\text { loops }\end{array}$ \\
\end{tabular} & $\begin{array}{l}\text { instrumentati } \\
\text { on }\end{array}$ & $\begin{array}{l}\text { fllow } \\
\text { instrument }\end{array}$ & $\begin{array}{l}\text { read fluid } \\
\text { flow } \\
\text { speed }\end{array}$ & \begin{tabular}{|l} 
instrument \\
but tot power \\
or signals
\end{tabular} & continuous & hands-on & $\begin{array}{l}\text { spurius } \\
\text { operation }\end{array}$ & $\begin{array}{l}4.3 E-06 \\
\text { per hour }\end{array}$ & & log normal & $\begin{array}{l}\text { spurious } \\
\text { operation }\end{array}$ & $\begin{array}{l}0.5 \text { per } \\
\text { hour }\end{array}$ & $\begin{array}{l}\text { not } \\
\text { given }\end{array}$ & \begin{tabular}{|l} 
point \\
estimate
\end{tabular} & \begin{tabular}{|l} 
spurious \\
operation
\end{tabular} & 0.1 & & \begin{tabular}{|l} 
point \\
estimate
\end{tabular} & $\begin{array}{l}\text { spurious } \\
\text { operation }\end{array}$ & & & \\
\hline \begin{tabular}{|l|} 
Primary \\
neat \\
transter \\
systems
\end{tabular} & \begin{tabular}{|l}
$\begin{array}{l}\text { neat } \\
\text { transter } \\
\text { loops }\end{array}$ \\
\end{tabular} & $\begin{array}{l}\text { instrumentati } \\
\text { on }\end{array}$ & $\begin{array}{l}\text { level } \\
\text { instrument }\end{array}$ & $\begin{array}{l}\text { read fluid } \\
\text { height tin } \\
\text { pressuriz } \\
\text { err }\end{array}$ & $\begin{array}{l}\text { instrument } \\
\text { but tot power } \\
\text { or signals }\end{array}$ & continuous & hands-on & $\begin{array}{l}\text { fail of tunction } \\
\text { on demand }\end{array}$ & & & & $\begin{array}{l}\text { fail to } \\
\text { tunntion on } \\
\text { demand }\end{array}$ & $\begin{array}{l}0.33 \text { per } \\
\text { hour }\end{array}$ & $\begin{array}{l}\text { not } \\
\text { given }\end{array}$ & \begin{tabular}{|l} 
point \\
estimate
\end{tabular} & $\begin{array}{l}\text { fail to } \\
\text { tunntion on } \\
\text { demand }\end{array}$ & 0.1 & & $\begin{array}{l}\text { point } \\
\text { estimate }\end{array}$ & \begin{tabular}{|l} 
fail to \\
function on \\
demand
\end{tabular} & $\begin{array}{l}2.1 E-04 \\
\text { per demand }\end{array}$ & & 3 l $\log$ normal \\
\hline \begin{tabular}{|} 
保位ary \\
tanster \\
systems
\end{tabular} & \begin{tabular}{|l} 
heat \\
transter \\
loops
\end{tabular} & $\begin{array}{l}\text { instrumentati } \\
\text { on }\end{array}$ & $\begin{array}{l}\text { level } \\
\text { instrument }\end{array}$ & 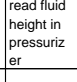 & \begin{tabular}{|l} 
instrument \\
but not power \\
or signals
\end{tabular} & continuous & hands-on & $\begin{array}{l}\text { spurious } \\
\text { operation }\end{array}$ & \begin{tabular}{|l}
$8.2 E-07$ \\
per hour
\end{tabular} & 5.6 & log normal & $\begin{array}{l}\text { spurious } \\
\text { operation }\end{array}$ & $\begin{array}{l}0.33 \text { per } \\
\text { hour }\end{array}$ & $\begin{array}{l}\text { not } \\
\text { given }\end{array}$ & $\begin{array}{l}\text { point } \\
\text { estimate }\end{array}$ & \begin{tabular}{|} 
spurious \\
operation
\end{tabular} & 0.1 & & \begin{tabular}{|l} 
point \\
estimate
\end{tabular} & \begin{tabular}{|} 
spurious \\
operation
\end{tabular} & & & \\
\hline
\end{tabular}

